\title{
An Evaluation of the Idaho Plate Method for Adults with Type 2 Diabetes and Limited Health Literacy in Rural West Virginia
}

\author{
Pamela L. Edens \\ West Virginia University
}

Follow this and additional works at: https://researchrepository.wvu.edu/etd

\footnotetext{
Recommended Citation

Edens, Pamela L., "An Evaluation of the Idaho Plate Method for Adults with Type 2 Diabetes and Limited Health Literacy in Rural West Virginia" (2013). Graduate Theses, Dissertations, and Problem Reports. 3632.

https://researchrepository.wvu.edu/etd/3632

This Dissertation is protected by copyright and/or related rights. It has been brought to you by the The Research Repository @ WVU with permission from the rights-holder(s). You are free to use this Dissertation in any way that is permitted by the copyright and related rights legislation that applies to your use. For other uses you must obtain permission from the rights-holder(s) directly, unless additional rights are indicated by a Creative Commons license in the record and/ or on the work itself. This Dissertation has been accepted for inclusion in WVU Graduate Theses, Dissertations, and Problem Reports collection by an authorized administrator of The Research Repository @ WVU. For more information, please contact researchrepository@mail.wvu.edu.
} 
An Evaluation of the Idaho Plate Method for Adults with

Type 2 Diabetes and Limited Health Literacy in Rural West Virginia

Pamela L. Edens, MSN, APRN, FNP-BC, BC-ADM
Doctoral Capstone Project submitted to the School of Nursing at West Virginia University in partial fulfillment of the requirements for the degree of

\author{
Doctor \\ of \\ Nursing Practice Degree
}

Kari Sand-Jecklin, EDD, MSN, RN, Chair

Lisa Hardman, DNP, RN

Jill Cochran, PhD, FNP-BC

Department of Nursing

Morgantown, West Virginia

April 19, 2013

Keywords: Type 2 Diabetes Mellitus; Limited Health Literacy, Idaho Plate Method; HbA1c Copyright 2013 Pamela L. Edens 


\begin{abstract}
An Evaluation of the Idaho Plate Method for Adults with

Type 2 Diabetes and Limited Health Literacy in Rural West Virginia

Pamela L. Edens, MSN, APRN, FNP-BC, BC-ADM
\end{abstract}

This capstone project evaluated the Idaho Plate Method (IPM) as an effective nutrition self-management program for adults with type 2 diabetes mellitus (T2DM) with limited health literacy (LHL) in one rural clinic in West Virginia. A one-way pretest-posttest design was used to evaluate the effects of the program on food choices, confidence, and HbA1c. A convenience sample of 30 volunteers participated in the program with 3-month follow-up data collected on 22 volunteers. A Wilcoxon test was conducted to evaluate choices of fruits, vegetables, and fatty foods and participant confidence in making healthful food choices. Data analysis found significant differences in fruit intake $(z=-1.98, p 0.05)$; vegetables intake $(z=-2.58, p .01)$; and skim milk intake $(\mathrm{z}=-2.094, p$.04). There was a decrease intake of French-fries and fried potatoes $(z=-2.26, p .02)$; butter or margarine on bread or pancakes $(z=-2.494, p .01)$; regular fat hot dogs $(z=-2.693, p<0.01)$; and total fat consumption $(z=-2.50, p .01)$. A significant increase in confidence was found in participants ability to prepare or share food with nondiabetics $(z=-3.10, p .002)$; to choose appropriate foods when hungry $(z=-2.72, p=.006)$; to eat smaller portions at dinner $(z=-2.46, p .014)$; and to add less fat than a recipe calls for $(z=-$ 2.10, p.035). Paired t-test analysis compared pretest-posttest HbA1c results with a very nearly significant difference between the HbA1c pretest $(M=7.96, S D=1.83)$ and posttest $(M=7.34$, $S D=1.60), t(24)=2.02, p .055)$. Limitations of the study included the study design, lack of participants with LHL, high attrition rate, and study time restraints. Conclusions found, despite limitations, adults in rural WV with T2DM increased confidence in making healthy food choices, choosing healthy foods, and improving their glycemic control using the IPM. 


\section{DEDICATION}

This author dedicates this Doctoral Capstone project to my family and friends. To my parents, Edward and Martha, who have always encouraged me to do my best in whatever I chose to do. Even though I lost my father during this journey, his spirit remains with me. To my children, Cyndi, Jamie, Nathan, and Randy, who have provided me with their love and support, and have repeatedly told me how proud they are of me. To my grandchildren, Joseph, Tucker, Jake, and Kyndall, who have given me permission to take a break and laugh when I needed it most. To my husband, James, who has shared this journey with me from the beginning; always listening; reminding me why I wanted to complete my DNP; and loving me despite everything. I must also thank a group of loved ones who never saw this day come to fruition, because they are counted in the statistics of those lost in the battle with diabetes--Grandma Ray, Peggie, Grandma and Grandpa Greer, Aunt Ruth, and Aunt Betty. Finally, I must thank my Lord and Savior Jesus Christ and my church family. Had it not been for my faith I would not have finished this journey. 


\section{ACKNOWLEDGEMENTS}

I wish to thank my committee members who were more than generous with their expertise and precious time. A special thanks to Dr. Kari Sand-Jecklin, my committee chairman for her countless hours of reflecting, reading, encouraging, and most of all patience throughout the entire process. Thanks also to my committee members-Dr. Jill Cochran, for being available every time I needed her as my mentor and as a great friend, and Dr. Lisa Hardman, for being a wonderful professor and example of what the DNP can be.

I also want to acknowledge my Robert C. Byrd Clinic family_administration, medical staff, nursing staff, and support staff for their assistance and encouragement during this process. Finally, I want to extend a very appreciative thank you to those who participated in my project. Without them, this project would have never happened, and I believe I learned as much from them as, I hope, they learned from me. 


\section{Table of Contents}

Introduction

Background

Diabetes Pathology 1

Diabetes Self-Management Education 3

Health Literacy $\quad 4$

Idaho Plate Method 5

Glycated Hemoglobin $\quad 6$

$\begin{array}{ll}\text { Significance of the Problem } & 7\end{array}$

$\begin{array}{lr}\text { Problem Statement } & 8\end{array}$

$\begin{array}{ll}\text { Theoretical Framework } & 9\end{array}$

An expression of the clinical problem and the theoretical framework. $\quad 10$

$\begin{array}{ll}\text { Literature Review } & 11\end{array}$

$\begin{array}{ll}\text { Search strategy. } & 12\end{array}$

$\begin{array}{ll}\text { Literature review findings. } & 12\end{array}$

$\begin{array}{ll}\text { Synthesis of the literature. } & 25\end{array}$

$\begin{array}{ll}\text { Capstone project Description } & 25\end{array}$

$\begin{array}{ll}\text { Stakeholders } & 26\end{array}$

$\begin{array}{ll}\text { Timeline } & 27\end{array}$

$\begin{array}{ll}\text { Resources } & 27\end{array}$

$\begin{array}{ll}\text { Participants } & 28\end{array}$

$\begin{array}{ll}\text { Objectives } & 28\end{array}$

$\begin{array}{ll}\text { Methods } & 29\end{array}$ 
$\begin{array}{lr}\text { Project Design } & 29\end{array}$

$\begin{array}{lr}\text { Inclusion Criteria } & 29\end{array}$

$\begin{array}{ll}\text { Program Description } & 30\end{array}$

$\begin{array}{ll}\text { Results } & 34\end{array}$

$\begin{array}{ll}\text { Demographics. } & 35\end{array}$

The Brief Patient Health Literacy Screen. 35

Education Program Evaluation. 36

$\begin{array}{ll}\text { Idaho Plate Method Evaluation. } & 36\end{array}$

$\begin{array}{ll}\text { Evaluation of Food Choices. } & 37\end{array}$

$\begin{array}{ll}\text { Evaluation of Confidence. } & 38\end{array}$

Evaluation of Glycemic Control. 38

Summary, Discussion, and Implications

$\begin{array}{ll}\text { Summary } & 39\end{array}$

$\begin{array}{ll}\text { Objective } 1 . & 39\end{array}$

$\begin{array}{ll}\text { Objective 2. } & 40\end{array}$

$\begin{array}{ll}\text { Objective } 3 . & 40\end{array}$

Unintended Consequences. $\quad 41$

$\begin{array}{ll}\text { Discussion } & 41\end{array}$

$\begin{array}{ll}\text { Theoretical Basis. } & 41\end{array}$

$\begin{array}{ll}\text { Limitations. } & 42\end{array}$

Implications. $\quad 43$

$\begin{array}{ll}\text { Conclusion } & 45\end{array}$

Attainment of Leadership Goals $\quad 45$ 
References

Appendices 
Index of Appendices

Appendix A $\quad$ Documentation of permission to use the health belief model 60

$\begin{array}{lll}\text { Appendix B } & \text { Using the Health Belief Model with Adults with }\end{array}$

Diabetes Type 2 with LH

Appendix C Capstone Completion Timeline

$\begin{array}{lll}\text { Appendix D } & \text { Final capstone budget } & 63\end{array}$

$\begin{array}{lll}\text { Appendix E } & \text { Capstone Site Administrative Support } & 65\end{array}$

$\begin{array}{lll}\text { Appendix F } & \text { WVSOM site approval } & 66\end{array}$

$\begin{array}{lll}\text { Appendix G } & \text { Idaho Plate Method Permission Document }\end{array}$

$\begin{array}{lll}\text { Appendix H } & \text { WVU IRB Approval Document }\end{array}$

$\begin{array}{lll}\text { Appendix I } & \text { Idaho Plate Method Power Point Script }\end{array}$

$\begin{array}{lll}\text { Appendix J } \quad \text { Idaho Plate Method Placemat } & 89\end{array}$

$\begin{array}{lll}\text { Appendix K } & \text { Idaho Plate Method Booklet } & 90\end{array}$

$\begin{array}{lll}\text { Appendix L } & \text { Idaho Plate Method Food Diary } & 101\end{array}$

$\begin{array}{lll}\text { Appendix M } & \text { Patient Recruitment Flyer } & 102\end{array}$

$\begin{array}{lll}\text { Appendix N } & \text { Patient Recruitment Letter } & 103\end{array}$

$\begin{array}{lll}\text { Appendix O } & \text { Brief Health Literacy Screen } & 104\end{array}$

$\begin{array}{lll}\text { Appendix P } & \text { Food Choices Questionnaire 1 } & 105\end{array}$

$\begin{array}{lll}\text { Appendix Q } & \text { Food Choices Questionnaire 2 } & 112\end{array}$

$\begin{array}{lll}\text { Appendix R } & \text { Idaho Plate Method Lesson Plans } & 117\end{array}$

$\begin{array}{lll}\text { Appendix S } & \text { Program Evaluation Form } & 122\end{array}$

$\begin{array}{lll}\text { Appendix T } & 3 \text { Month Mid-Point Telephone Script } & 124\end{array}$

$\begin{array}{lll}\text { Appendix U } & 3 \text { Month Follow-up Telephone Script } & 125\end{array}$

$\begin{array}{lll}\text { Appendix V Provider Notification Letter } & 126\end{array}$ 
An Evaluation of the Idaho Plate Method for Adults with

Type 2 Diabetes and Limited Health Literacy in Rural West Virginia

The aims of the Healthy People 2020 goals for people with diabetes are to improve quality of life, reduce the rate of complications, decrease the diabetes death rate, and lower the economic burden attributed to the disease (United States [US] Department of Health and Human Services, 2011). In order to achieve these goals, individuals with diabetes must not only possess the ability to understand health information, they also must have the ability to use that information to make health care self-management changes that can improve their lives. However, within the Appalachian culture, where diabetes is one of the most frequent chronic diseases reported among adults (Lohri-Posey, 2006), change may be difficult to attain due to marked limitations regarding healthcare/illness knowledge and understanding (Denham, Meyer, Toborg, \& Mande, 2004). For adult patients with type 2 diabetes mellitus (T2DM), living in West Virginia (WV) with limited health literacy (LHL), a program designed to improve understanding and to make positive changes in diabetes self-management should enhance quality of life. The purpose of this capstone project was to evaluate the effectiveness of a diabetes self-management nutrition intervention for adults with T2DM and LHL in rural WV.

\section{Background}

\section{Diabetes Pathology}

Diabetes mellitus is a heterogeneous group of metabolic disorders characterized by alterations in glucose metabolism (Wynne, 2007). The most prevalent types of diabetes are type 1 and type 2 . The diagnosis of type 1 diabetes is usually made in children and young adults and accounts for $5-10 \%$ of all persons diagnosed with diabetes mellitus (American Diabetes Association [ADA], 2011b). Type 1 diabetes occurs as a result of autoimmune, nonimmune, or 
idiopathic pancreatic beta cell destruction in the islets of Langerhans (Wynne, 2007). Without the ability to make endogenous insulin, the person requires insulin replacement to sustain life (Centers for Disease Control and Prevention [CDC], 2011b; Weir, Donahue, \& Roederer, 2008; Wynne, 2007).

Insulin resistance is the hallmark of T2DM which is usually diagnosed later in life (ADA, 2011b), and accounts for 90 to $95 \%$ of all diagnosed cases (CDC, 2011a). The pathophysiology of insulin resistance occurs because of lipolysis of adipose tissue, which leads to an elevation in circulating free fatty acids (Unger, 2007). Free fatty acids infiltrate the pancreatic beta cells, thus decreasing the cells ability to secrete insulin (Weir et al., 2008). Increased free fatty acids also impairs the action of insulin through decreased glucose utilization in the skeletal muscles, decreased glucose uptake in the adipose tissue, and increased hepatic glucose production—all of which lead to hyperglycemia (Unger, 2007).

Hyperglycemia is cytotoxic to pancreatic beta cells (Weir et al., 2008). Consequently, to the damaged beta cells, insulin resistance results from mutations of the insulin receptors within one of the many intracellular insulin-signaling systems (Unger, 2007). Thus the cyclic eventbeta cell destruction, impaired insulin receptors, insulin resistance, decreased insulin secretion, hyperglycemia, and beta cell destruction—occurs.

Well known risk factors for T2DM includes older age, obesity, family history of diabetes, prior history of gestational diabetes, impaired glucose tolerance, sedentary lifestyle, and ethnicity (CDC, 2011b). Morbidity associated with the disease includes both acute complications and chronic macrovascular and microvascular complications. The macrovascular complications include coronary artery disease, peripheral arterial disease, and stroke (ADA, 2011a). The microvascular diseases include diabetic nephropathy, neuropathy, and retinopathy (ADA, 
2011a). Diabetes is the leading cause of blindness, kidney failure, and non-traumatic lower-limb amputations in the US and a major cause of heart disease and stroke (CDC, 2011a).

Guidance from health care professionals is often necessary to assist people with diabetes in the prevention of complications. The ADA provides care and management guidelines for those with diabetes as well as for those who treat people with the disease (ADA, 2013). Among the goals for diabetes self-management is education, healthy eating, and attainment of blood glucose targets (ADA, 2013).

\section{Diabetes Self-Management Education}

With prevention of diabetes complications as a goal of Healthy People 2020 (US Department of Health and Human Services, 2011), diabetes self-management education (DSME) is a critical component for providers who offer health care to those with diabetes (Hass et al., 2013). Diabetes self-management education is an ongoing process by which people with diabetes are given the knowledge, skills, and abilities to self-manage their disease (Hass et al., 2013). Research indicates that people with diabetes who receive DSME are four times less likely to develop complications than those with no education (Kent et al., 2013). Diabetes selfmanagement education can reduce healthcare utilization, costs, and disabilities (Basu, Allenson, McLellan, \& Hochhalter, 2012).

Diabetes self-management education, which is a covered benefit by all government and most private insurance carriers, is cost-effective and improves health outcomes as patients improve their glycated hemoglobin (HbA1c) (American Association of Diabetes Educators [AADE], 2010). The reimbursement rate for individual DSME in WV per 30 minutes is $\$ 52.06$, and the reimbursement rate for group DSME in WV per 30 minutes per patient is $\$ 13.95$ (Centers for Medicare \& Medicaid Services, 2013). However, the real benefit to cost ratio of 
DSME was found in health outcomes. Research has shown there is a per person savings of $\$ 918$ for the first year after DSME, there is a return investment of $\$ 4.34: 1$ when disease management is combined with DSME; and DSME that improves nutrition knowledge and glycemic control can reduce medical costs by $\$ 94,010$ per person over a lifetime (Boren, Fitzner, Panhalkar, \& Specker, 2009).

The National Standards for DSME and Support (Hass et al., 2013) provides the criterion by which providers of DSME can ensure high quality, effective education for their patients with diabetes. The standards emphasize that the focus of DSME must be on the person with diabetes (Hass et al., 2013); after all, they are the ones who bear the burden of the disease. In the development of DSME programs, designers must consider the population for which the program will be directed. Population characteristics such as health literacy can affect the success of a DSME program (Anderson et al., 2012). Research has shown that people with T2DM are more likely to achieve DSME program goals when health literacy strategies were used (Koh, Brach, Harris, \& Parchman, 2013).

\section{Health Literacy}

Health literacy is more than reading, writing, and arithmetic. According to the Institute of Medicine, health literacy is the ability to "obtain, process, and understand basic health information and services needed to make appropriate health decisions" (What is health literacy, 2004, p. 32). Self-management of one's health requires the ability to understand and follow healthcare recommendations (Sealy \& Weiner, 2007). In order to accomplish these tasks, individuals may need to critically think and question, understand graphs or other visual information, operate a computer, obtain and apply relevant information, and calculate or reason numerically (Bohanny et al., 2013). Unfortunately, most people in the US have difficulty in one 
or more of the components of health literacy: print literacy, oral literacy, and numeracy (Koh et al., 2013). In fact, the Department of Education's National Assessment of Adult Literacy states that only $12 \%$ of adults in the US can understand and use health information proficiently (Koh et al., 2013).

According to Nath (2007, p 44), "health literacy is a stronger predictor of health status than is socioeconomic status, age, or ethnic background." Those with diabetes and LHL may have poor disease knowledge and are less likely to recognize impending health complications (White, Wolff, Cavanaugh \& Rothman, 2010). There is also increased risk of complications for the person with diabetes and LHL because nonparticipation in health promotion activities is worse for individuals who are poorly educated (Pearson et al., 2001).

Even for the well educated, trying to understand complex instructions about how to control blood glucose, follow medical nutrition advice, and prevent health complications can be daunting, but for the individual with T2DM and LHL, the task can become impossible. According to Schilling et al. (2002), LHL is associated with poor glycemic control and microvascular complications among disadvantaged populations. Therefore, when educating patients with T2DM and LHL, it is necessary to use materials that recognize the problems these learners face.

\section{Idaho Plate Method}

Many available instruments address health literacy in DSME. The plate method is a simple meal-planning instrument used to educate people with diabetes about meal planning (Kaiser et al., 2009). First used in Europe, the plate model was used in the Diabetes Atherosclerosis Intervention Study (DAIS) (Camelon et al., 1998; Steiner, 1996), and was found to be as effective as exchange-lists for teaching medical nutrition therapy to people with diabetes 
(Delanhanty \& Heins, 2008). Using the DAIS information, a group of dieticians in collaboration with the University of Idaho Extension Services developed the Idaho Plate Method (IPM) following ADA and American Dietetic nutritional guidelines (Rizor, Smith, Thomas, Harker, \& Rich, 1998).

The IPM uses low literacy illustrations, color-coding, and basic numeracy to teach meal planning and portion control, and has been recommended for people who have diabetes with LHL (IPM, 2011). Programs that have used the IPM for DSME include Dining with Diabetes (West Virginia University [WVU] Extension Service, 2011), The Healthy Diabetes Plate (Raidl et al., 2007), and Meals Made Easy for Diabetes (Oregon Diabetes Program, 2006). The IPM has also been used extensively in nutrition research (Coffman, Ferguson, Steinman, Talbot, \& Dunbar-Jacob, 2013; Cortes, Milan-Ferro, Schneider, Vega, \& Caballero, 2013; Sealy et al., 2012; Kaiser et al., 2009; Raidl et al., 2007; Brown, Lackey, Miller, \& Priest, 2001). However, literature could not be found where the program was used to teach DSME to people with T2DM and LHL in rural WV.

\section{Glycated Hemoglobin}

In addition to self-management education and healthy eating, people with T2DM must also strive to attain blood glucose goals to prevent the complications of diabetes. Home blood glucose monitoring provides prompt glucose readings, and is a valuable tool for diabetes selfmanagement (Benjamin, 2002). According to the ADA, the target blood glucose readings are 70$130 \mathrm{mg} / \mathrm{dl}$ fasting and $<180 \mathrm{mg} / \mathrm{dl}$ 2-hour postprandial (ADA, 2013).

Glycated hemoglobin, or HbAlc, is another blood glucose value that is important for the person with T2DM to know. The HbAlc measures the percentage of glucose molecules adhered to hemoglobin in the red blood cells; a normal non-diabetic HbA1c is 3.5-5.5\% (ADA, 2013). 
The ADA have set the goal HbAlc at $<7 \%$, which is equivalent to a mean plasma glucose of 154 mmol/L (2013). For every percent the HbAlc drops, the average mean plasma glucose drops approximately $29 \mathrm{mmol} / \mathrm{L}$. Research shows a drop of $0.5 \% \mathrm{HbAlc}$ is a clinically significant change (Nathan et al., 2009; National Institutes of Health and Clinical Excellence, 2009), and by lowering the $\mathrm{HbAlc}$ by $1 \%$ the risk of diabetes retinopathy, diabetes neuropathy, diabetes nephropathy, and many cardiovascular complications can be reduced (Baker, 2013).

\section{Significance of the Problem}

Diabetes and the complications associated with it, cause tremendous individual and public burden (Norris, Lau, Smith, Schmid, \& Engelgau, 2002). According to the World Health Organization (WHO), 347 million people worldwide have diabetes (WHO, 2013). The 2012, World Health Statistics estimates that 3.4 million people died in 2004 because of the consequences of diabetes, and this number is only expected to increase (WHO, 2013).

Within the US, 25.6 million people, or $11.3 \%$ of adults age $\geq 20$ years have diabetes, and, of those age $\geq 60$ years, 10.9 million or $26.9 \%$ have diabetes (CDC, 2011a). Pre-diabetes affects another 79 million (Feheley, 2013). If the current prevalence rate continues, by the year 2050 one-third of the adult population in the US will have diabetes (Kent et al., 2013).

The annual direct medical costs of diabetes are $\$ 176$ billion, the indirect costs total $\$ 69$ billon, and the average cost of medical expenditure is 2.3 times more for people with diabetes than for those without diabetes (Feheley, 2013). The majority of the diabetes health care costs (62.4\%) are paid by government insurance including Medicare, Medicaid, and the military (Feheley, 2013). As with diabetes, the cost of LHL to the US economy is staggering. It is estimated that poor health literacy accounts for $\$ 106$ billion to $\$ 238$ billion annually, and 
represents 7 to $17 \%$ of all health care expenditures (Vernon, Trujillo, Rosenbaum, \& DeBuono, 2007).

When comparing WV to the national diabetes statistics, WV has consistently ranked in the upper percentages of populations with diabetes (Stohr, 2012). Of the US population with diabetes, WV is ranked third with $12 \%$ of adults diagnosed with the disease (United Health Foundation, 2012). People with T2DM living in WV are more likely to be older, earn less money, and have less education than those without diabetes (Stohr, 2012). This is significant in that older age, low income, depressed economic background, low education attainment, and chronic illness are predictors of LHL (Weiss, 2007; Nutbeam, 2000).

Of adults living in Greenbrier County, WV, with a total population of 35,800 (US Census Bureau, 2013), 12.4\% have been told they have diabetes (CDC, 2012). This is not surprising in that the population is older with a median age of 45 years and $19.4 \%$ are age 65 or older (US Census Bureau, 2010). In addition, the people of Greenbrier County are poorer with a median household income of $\$ 35,180$, which is $\$ 16.5$ thousand less than the national average; $19.3 \%$ of Greenbrier County residents live below the poverty level (US Census Bureau, 2013). Of persons with a diagnosis of diabetes in the county, $40 \%$ have less than a high school education, compared to $20.3 \%$ of those without diabetes (WV Department of Health and Human Resources, 2007). Therefore, using a program that teaches those with T2DM and LHL how to follow a selfmanagement nutrition plan that can improve glycemia, the complications associated with the disease and thus the costs of the disease will decrease.

\section{Problem Statement}

Greenbrier County, WV has a high prevalence rate of diabetes among adults as well as high risk of LHL due to older age of the population, lower income, and lower education levels. 
Therefore, Greenbrier County represents a good target population for a DSME nutrition project.

The research question for this capstone project is can the IPM improve diabetes self-management for adults with T2DM and LHL in rural WV as measured by patient selection of more healthy food choices, more confidence in making healthy food choices, and improved HbAlc?

\section{Theoretical Framework}

The development of a DSME dietary project for people with T2DM that can help prevent complications can be a difficult and challenging undertaking (Snetselaar, 2008). However, a nutritional intervention is more likely to produce positive results when based on established theory (Wallace et al., 2012). A search of the literature found many theoretical models used in nutrition intervention, among them situated learning theory (Coffman, Ferguson, Steinman, Talbot, \& Dunbar-Jacob, 2013), PRECEDE-PROCEED (Hardin-Fanning, 2013), the chronic care model (Siminerio et al., 2008), social cognitive theory (Strychar, Elisha, \& Schmitz, 2012), and the health belief model (Della, 2011). The theoretical framework to guide this project was the health belief model, which examines the perceptions of health (Snetselaar, 2008). Approval to use the theoretical model was obtained from the Milbank Memorial Fund. (See Appendix A for approval document.)

The health belief model is based on four key elements: 1) perceived risk of disease; 2) belief of severity of disease; 3 ) perceived benefit of prescribed therapy to prevent or reduce the seriousness of the disease; and 4) one's ability to overcome barriers to accept change (Rosenstock, 1966). Recent revisions of the health belief model added three additional key elements to the model (Hayden, 2009). The fifth element is cues to action, or those behaviors or actions that will prompt a person to change behavior. The sixth element is modifying variables, which address characteristics that influence personal perceptions (Hayden, 2009) such as culture, 
literacy, habits, etc. Finally, the seventh element is self-efficacy or the personal belief that one has the ability to make changes in one's life (Hayden, 2009).

Expression of the clinical problem and the theoretical framework. The US

Department of Agriculture's Dietary Guidelines for Americans describe a healthy diet as one that emphasizes fruits, vegetables, whole grains, and low-fat food options (2010). However, the United Health Foundation (2012) reports the diets of West Virginians are low in fruits and vegetables and high in fats - dietary habits that can lead to health problems. Unfortunately, with Appalachian values being deep-rooted and opposed to change (Marcum, 2008), it can be assumed that the people of WV do not recognize their diets to be problematic. Furthermore, before a DSME program can generate dietary changes, participants must first perceive their current diets to be a problem (Griffith, Lovett, Pyle, \& Miller, 2011).

Therefore, when considering the people of WV, a DSME program must consider food preferences, family traditions, and intergenerational dietary habits when considering any project that proposes to change customary diets (Denham, Manoogian, \& Schuster, 2007). The health belief model "attempts to explain and predict health behaviors by focusing on the attitudes and beliefs" of individuals (Snetselaar, 2008, p. 139). Consequently, by incorporating the concepts of the health belief model into a dietary DSME program for people of Appalachian culture, program success is promising.

Individual perceptions regarding perceived risk of T2DM complications is the belief that the complication will occur if a healthy diet that lowers HbAlc is not followed. The perceived severity is the belief of how critical that complication may be. For example, if a person with T2DM continues to consume high carbohydrate, high fat foods; they will eventually develop chronic kidney disease. To reduce the threat of diabetes complications, the individual must 
recognize that the perceived benefits (normal kidney function and improved $\mathrm{HbAlc}$ ) will outweigh the perceived barriers (lack of spontaneity in food choices and cost of new foods).

The perceived barriers include those obstacles to behavior change, such as LHL, poor understanding of nutrition, and non-compliance of prescribed medical nutrition therapy. For the individual to choose to make positive health behavior changes, modifying factors must be considered. Modifying factors includes demographic variables — age, sex, race, and ethnicity; socio-psychological variables - personality, culture, and peer group; and structural variablesknowledge about T2DM and health literacy. Cues to action, such as voluntarily participating in diabetes self-management classes, knowing blood glucose goals, and learning about portion control, are measures that will lead a person to positive behavior change. Finally, a person can acquire self-efficacy because of DSME with the acquisition of self-confidence to better manage their T2DM and make healthier food choices, thus improve glycemic control as evidenced by improved HbAlc. (Use of the health belief model with T2DM is described in Appendix B.)

\section{Literature Review}

A thorough search of databases for literature to identify the best evidence related to a nutritional intervention for adults with T2DM and LHL in rural WV was conducted. Databases searched included the National Guidelines Clearinghouse, Cochrane Review/Library, PubMed, Google Scholar, and WVU Full-text Database using Elton B. Stephens Company (EBSCO) Host to search Academic Search Complete, Health Source: Nursing/Academic Edition, and Cumulative Index to Nursing and Allied Health Literature (CINAHL). Inclusion criteria for the literature search included human studies only, adult age 18 and older, peer-reviewed, English language, and years 2000-2011. The literature search words and combinations were type 2 
diabetes, health literacy, self-management, self-efficacy, glucose, nutrition, glycated hemoglobin, $\mathrm{HbA1c}$, and various combinations of these words and phrases.

Search strategy. Within the Databases, the initial search of key words led to 111 hits in National Guidelines Clearing House with two relevant clinical guidelines located (ADA, 2011a; \& American Association of Diabetes Educators, 2011). A search of the Cochrane Library Database produced 184 hits with two relevant systematic reviews. However, neither fit the inclusion criteria for the literature review question. A search of full text databases yielded 290 thousand hits in Google Scholar with one relevant article. A search of PubMed resulted in 122,112 hits with three relevant articles. A search of Health Source: Nursing/Academic Edition produced 21,249 hits with six relevant articles. There were 2,580 hits in CINAHL with six relevant articles; 9,725 hits in MedLine with three relevant articles; and 44,755 hits in Academic Search Complete with four relevant articles. Of the articles reviewed from the databases, ten were chosen for further evaluation, and five were chosen for inclusion. Using snowballing technique, eight additional articles were selected for inclusion according to the search criteria.

Literature review findings. The National Guideline Clearinghouse search produced two relevant guidelines. The ADA Standards of Medical Care in Diabetes, 2011, was chosen as the first of the clinical guidelines (ADA, 2011a). The guidelines provide nutritional benchmarks for diabetes control and management that were originally stated in a position statement (ADA, 2008, p. S61) and direct individuals with diabetes to:

1. Achieve and maintain blood glucose levels in the normal range or as close to normal as is safely possible.

2. Prevent or slow the rate of development of the chronic complications of diabetes by modifying nutrient intake and lifestyle. 
3. Address individual nutrition needs, taking into account personal and cultural preferences and willingness to change.

4. Maintain the pleasure of eating by limiting food choices only when indicated by scientific evidence.

The ADA also made nutritional recommendations for achieving glycemic control. These evidence based recommendations include clear evidence that patients with T2DM should receive DSME concerning carbohydrate intake through diets that incorporate carbohydrate counting, exchange lists, or carbohydrate experienced-based estimation. In addition, through wellconducted cohort studies, evidence was found that diets should encourage carbohydrates from fruits, vegetables, whole grains, legumes, and low-fat milk. An expert consensus also directs that self-blood glucose monitoring can determine whether making change in one's diet is sufficient to meet one's blood glucose goals, or if medication needs to be added with nutritional management to achieve those goals (ADA, 2011a).

The AADE Guideline for the Practice of Diabetes Education (2011) outlines the overall objectives to increase access to DSME and training. The target populations are those individuals with type 1 diabetes mellitus, T2DM, gestational diabetes, and those with secondary forms of diabetes (Ganda, 2005). The guideline provided evidence that supported the development of this capstone DSME project.

A weakness of the guideline was that it did not specifically address health literacy in the practice considerations. The AADE did however issue an official position statement on this concern (Funnell, 2007). Health literacy is relevant for DSME. People with low health literacy have been shown to have poor glycemic control and disease outcomes (Funnell, 2007). According to Funnell (2007), effective self-management of disease requires an individual to be 
able to read, write, speak, compute, and problem-solve. Therefore, all patients must be assessed for health literacy as part of an individualized assessment process, and healthcare information must be provided at a level that the patient can understand.

In a randomized, single blind, controlled study, Atak, Gurkan, \& Kose (2008) evaluated the effects of patient education on knowledge, self-management, and self-efficacy in adult patients with T2DM. Eighty patients were randomly assigned either to an intervention group who received diabetes education or to the control group who received usual care. A pretest-posttest design was used to measure diabetes knowledge, self-management behaviors, and diabetes selfefficacy. The follow-up was conducted two weeks after the intervention.

The results showed a significant difference between the intervention and control groups in recognizing high calorie foods ( $p 0.037)$, recommended daily fat distribution $(p 0.024)$, controlling blood glucose levels to avoid complications ( $p$ 0.002), and diabetes self-efficacy ( $p$ 0.006). Conclusions drawn from the study show that the patient education intervention had limited effect on knowledge and diabetes self-management behaviors, but there was a statistically significant effect on self-efficacy in patients with T2DM.

The strengths of the study included a randomized control study with blinding of the subjects to group assignment. The Diabetes Self-Efficacy Scale, which is both valid and reliable, was used to measure the subject's self-efficacy. The weaknesses identified include the small sample size, the lack of long-term follow-up, and the use of tools to test patient knowledge and self-management that lacked proven validity and reliability.

In a randomized controlled trial (RCT), (Rothman et al., 2004) the objective was to examine the role of literacy on the effectiveness of a comprehensive disease management program for patients with diabetes. Study participants included 217 people, age 18 years and 
older with T2DM and poor glycemic control from one study site. More than one third of the participants had low literacy.

All participants attended a one-hour educational session and received treatment recommendations concerning glycemic control and cardiovascular risk. The participants were randomly assigned with concealed allocation into either the intervention group or the control group. The control group received usual care from their primary care providers following the initial education session. The intervention group received intensive diabetes management education from a multidisciplinary diabetes care team that included one-to-one counseling and medication management. The intervention group was also contacted via telephone by the diabetes care team every two to four weeks. Topics discussed by the diabetes care team included treatment goals, identification of and treatment of acute complications, prevention of long-term complications, and self-care management.

Among the outcomes measured was HbA1c levels. Follow-up data were reported on 193 (89\%) of the subjects at 12 months. The results show that those patients with low literacy in the intervention group were more likely than the control group to achieve goal HbA1c levels $(\leq$ $7.0 \%, 42 \%$ vs. $15 \%$, respectively; adjusted odds ratio (OR), $4.6 \% ; 95 \%$ confidence level (CI), 1.3 to $17.2 ; p 0.2)$. There was no significant difference in $\mathrm{HbAlc}$ levels in patients with high literacy between groups $(p .98)$. The conclusions drawn from the study show that a DSME program that addresses literacy levels can help improve diabetes outcomes.

The strengths of the study were found in the fact that it was a RCT with a randomly assigned, concealed allocation of study participants. The study also had an appropriate follow-up period of one year, with low attrition. A weakness in the design was found in the single-site study, which reduces generalizability. 
Pederson, Kang, and Kline (2007) conducted a RCT to determine if a portion control plate would improve glycemic control among patients with T2DM. The study was conducted at a single outpatient diabetes center. Participants included 130 people with 65 subjects in each group. The intervention group received the portion control tools; the control group was given usual care. The results of the study showed no difference in $\mathrm{HbAlc}$ levels between the intervention group when compared to the control group (respectively, $0.22 \pm 0.86(\mathrm{n}-51) ;-0.02$ $\pm 1.14(\mathrm{n}-52) ; p .23)$.

The strengths of the study were the random assignment of participants to treatment groups, low attrition with $93 \%$ follow-up at the end of the study. There were also no differences in diabetes measures between the treatment and the control groups, and all relevant outcomes were measured in a standard, valid, and reliable way. The limitations of the study were lack of concealment and blinding due to the nature of the study, and the acknowledgement that one participant in each group started an unrelated commercial weight loss diet during the study period; however, data from these two subjects were included in all analysis without an explanation as to why.

Ziemer et al. (2003) compared a simple meal plan emphasizing healthy food choices with a traditional exchange-based meal plan to evaluate $\mathrm{HbA1c}$ levels in urban African Americans with T2DM. This RCT with a six-month follow-up was conducted in one study location. There were 648 patients in the study with 359 in the control group and 289 in the intervention group. $\mathrm{HbAlc}$ and dietary practices were among the outcomes measured.

The study found that improvements in glycemic control over the six months were significant, but similar in both groups ( $p<0.0001$ for both). At the six-month follow-up, $41 \%$ of the intervention group and $32 \%$ of the control group had achieved goal HbAlc of $7.0 \%$ or less $(p$ 
0.12 between groups). Both groups exhibited similar improvement in dietary practices with respect to intake of fats $(p<0.01)$ and sugar sweetened foods $(p<0.01)$. Conclusions drawn from the study were that meal plans that emphasize healthy food choices may be easier to teach, and easier for patients with low literacy to understand and follow.

The strengths of the study were that it was at RCT, the study stated an appropriate and focused research question, and there were no significant differences between the intervention and control groups in age, ethnicity, gender, basal metabolic index, or $\mathrm{HbAlc}$ at baseline. Limitations of the study included that concealment was not used or addressed. In addition, two participants were permitted to switch from one arm of the study to the other without explanation as to why. This practice could have biased the results.

Powell, Hill, and Clancy (2007) conducted a multivariable linear analysis to explore the relationship between health literacy, patients' readiness to take health actions, and diabetes knowledge among patients with T2DM. The researchers administered the Rapid Estimate of Adult Health Literacy in Medicine (REALM) literacy instrument to 68 patients with T2DM. The study participants then completed the Diabetes Health Belief ModelScale and Diabetes Knowledge Test.

Multiple linear regression was used to assess the association between REALM literacy level, Diabetes Knowledge Test score, and the Diabetes Health Belief Model Scale score and most recent $\mathrm{HbA} 1 \mathrm{c}$ level. The results of the study show no significant association between Diabetes Health Belief Model Scale score and REALM literacy level ( $p$ 0.29). However, Diabetes Knowledge Test score and HbA1c were found to be significantly associated with the patient's literacy level ( $p .004 ; p .002$, respectively). The conclusions drawn from the study indicate that a patient's glycemic control is directly related to their health literacy. 
The strengths of the study are the use of valid and reliable tools. Low attrition rate is also recognized as strength of the study. The weaknesses of the study were noted to be the use of one study site and a weak study design.

Sarkar, Fisher, and Schillinger (2006) used a descriptive design to investigate the association between ethnicity, health literacy, and self-efficacy on self-management of T2DM. The investigators used an ethnically diverse population of 408 participants from two study sites. The majority of the subjects had LHL as evaluated by the short version Test of Functional Health Literacy in Adults (s-TOFHLA). Self-efficacy was measured with a disease-specific Likert-scale, and self-management was measured with the Summary of Diabetes Self-Care Activities Questionnaire. The conclusions drawn from the study show that self-efficacy was associated with self-management behaviors. Additionally, self-management interventions, which focus on self-efficacy, may be valuable in helping patients with LHL in the management of their disease.

The strengths of the study were found in the use of reliable and valid tools. In addition, the study was conducted in more than one site with a moderate number of participants included in the study. The weaknesses of the study included the lack of a valid and reliable tool to measure self-efficacy, and a weak study design.

Using a cross-sectional observational design, 408 ethnically diverse patients with T2DM participated in a study to examine the association between health literacy and T2DM outcomes (Schillinger et al., 2002). The study was conducted at two sites. Health literacy was assessed using the s-TOFHLA in both English and Spanish, and the most recent HbA1c was used as the main outcome measure.

The study found that for each one-point decrement in s-TOFHLA score, the HbA1c value increased by $0.02 \%(p 0.02)$. The study also found that the literacy levels of the study 
participants significantly changed the HbA1c levels $(\mathrm{HbA} 1 \mathrm{c} \leq 7.2 \%$; adjusted $\mathrm{OR}, 0.57 ; 95 \% \mathrm{CI}$, $0.32-1.00 ; p 0.05)$. Study participants with low literacy were more likely to have poor glycemic control (HbAlc $\geq 9.5 \%$; adjusted OR, 2.03; 95\% CI, 1.11-3.73; $p$ 0.02). The strengths of the study were the use of valid and reliable tools to measure health literacy, ethnically diverse participants, and multiple study sites. The primary weakness was the study design.

Cavanaugh et al. (2008) also conducted a cross-sectional study to examine the association between numeracy and diabetes control. The study was conducted at four sites with 398 participants with type 1 and 2 diabetes. The independent variables included health literacy, general numeracy, and diabetes-related numeracy, which was assessed using the REALM, Wide Range Achievement Test, $3^{\text {rd }}$ ed. (WRAT-3), and the Diabetes Numeracy Test. The primary outcome was most recent HbAlc. Secondary outcomes included diabetes knowledge, perceived self-efficacy of DSME, and self-management behaviors.

The results showed that lower Diabetes Numeracy Test scores are associated with older age, non-white race, less years of formal education, lower income, low literacy, low numeracy skills, lower self-perceived self-efficacy, and selected diabetes self-management behaviors ( $p<$ 0.001 for all). Patients who scored the lowest on the Diabetes Numeracy Test $(<42 \%)$ had a median $\mathrm{HbA} 1 \mathrm{c}$ level of $7.6 \%$ compared to $7.1 \%$ for those who scored the highest ( $p 0.119$ for trend). The conclusions found that low diabetes numeracy skills are associated with lower selfperceived self-efficacy, poor self-management behaviors, and poor glycemic control. The strengths of the study were the use of valid and reliable tools to measure health literacy and multiple study sites; the weakness was the study design.

Osborn, Cavanaugh, Wallston, White, and Rothman (2009) also studied diabetes numeracy. A cross-sectional study design was used to examine health literacy, general 
numeracy, and diabetes numeracy to explain the association between African American race and poor glycemic control in patients with T2DM. The study was conducted at four sites with 383 participants, 134 of the participants were African American, and all participants had either type 1 diabetes or T2DM. Health literacy was assessed using the REALM, general numeracy was measured using the WRAT-3, diabetes numeracy was measured using the Diabetes Numeracy Test, and glycemic control was assessed using the most recent $\mathrm{HbAlc}$ in the patient's medical record.

Of the 383 participants, $31 \%$ had less than a ninth grade reading level on REALM, and $69 \%$ had less than a ninth grade numeracy level on WRAT-3. The median Diabetes Numeracy Test score was $65 \%$ (42-81\%). The median HbA1c was $7.2 \%$ (6.5-8.3\%).

The study involved two parts. Model 1 tested whether African American race was a predictor of $\mathrm{HbAlc}$ levels after controlling for age, sex, education, income, insulin usage, type of diabetes, and years of diabetes diagnosis. The significant findings in Model 1 found that younger age $(r=0.27, p<0.001)$, using insulin $(r=0.27, p<0.001)$, having a diagnosis of diabetes for a longer time $(r=0.16, p<0.01)$, and African American race $(r=0.12, p<0.0 .01)$ were associated with higher $\mathrm{HbAlc}$ levels.

The significant findings from Model 1 were carried over to Model 2. In addition, the REALM scores, WRAT-3 scores, and the Diabetes Numeracy Test scores were included in Model 2 as explanatory factors in the predicted pathway from African American race to $\mathrm{HbAlc}$ levels. The explanation of the path coefficients suggest that African American race is associated with limited literacy skills $(r=-0.39, p<0.001)$, limited general numeracy skills $(r=-0.43, p<$ $0.001)$, and limited diabetes numeracy skills $(r=-0.46, p<0.001)$. The higher Diabetes 
Numeracy Test scores were associated with lower HbAlc levels $(r=-0.15, p<0.01)$, thus reducing the association of African American race to nonsignificant $(r=0.10, \mathrm{NS})$.

Conclusions drawn from the study found that low diabetes-related numeracy, not African American race, was significantly related to poor glycemic control. The strengths of the study are the use of valid and reliable tools to measure health literacy and multiple study sites. The weakness of the study was the use of a cross-sectional study design.

Tang, Pang, Chan, Yeung, \& Yeung (2008) examined the relationship between health literacy, complication awareness, and diabetes control among 149 patients with T2DM in a descriptive correlation study. The study was conducted at one study site in China. A modified version of the s-TOFHLA was used to test health literacy and a modified version of the Summary of Diabetes Self-Care Activities was used to measure complication awareness. Glycemic control was assessed by the most recent HbAlc.

The findings show a negative correlation of health literacy $(p<0.001)$ and complication awareness scores to diabetic control ( $p$ 0.035). However, treatment management using the Summary of Diabetes Self-Care Activities measure was positively correlated to HbA1c ( $p$ 0.03), gender ( $p$ 0.023), and duration of diabetes $(p<0.001)$. The conclusions drawn from the study state that in order for a patient education program to be effective, the patients' health literacy and self-care skills must be addressed. The strengths of the study are the use of valid and reliable tools; the weakness of the study was the study design.

Kim, Love, Quistberg, and Shea (2004) conducted a prospective observational study to examine the association between health literacy and self-management behaviors in patients with diabetes. The purpose of the study was to determine whether diabetes education improves selfmanagement behaviors in patients with LHL. The study was conducted at a single location with 
92 participants. The participants were chosen from adults patients who were already scheduled to receive or were receiving diabetic education at the research facility.

At the first class, the researchers administered the s-TOFHLA to measure health literacy, the Summary of Diabetes Self-Care Activities to measure self-management behaviors, and the Diabetes Knowledge Questionnaire to measure diabetes knowledge. The participants were then separated into two groups for comparison of data — adequate health literacy and LHL (which included marginal and low health literacy). Classes consisted of an individual meeting with a diabetic educator and three weekly three-hour group meetings. At the three-month follow up, paired $t$ tests showed improvement in $\mathrm{HbAlc}$, diabetes knowledge, and self-management behaviors for both the adequate health literacy group and the LHL group. However, the LHL group performed better in some of the self-management behaviors (diet, foot care, and selfglucose monitoring) than did the adequate health literacy group (28.6\% vs. $17.6 \%, p 0.276)$.

The strength of the study is the use of valid and reliable tools to measure health literacy, self-management behaviors, and diabetes knowledge. A threat to the internal validity of the study was the fact that participants were previously enrolled in the site's diabetic education program; therefore, the findings may not have been representative of all diabetic patients. A threat to the external validity of the study was a small sample size and high attrition rate $(16 \%$ overall, LHL $24 \%$, adequate health literacy $14 \%$ ). In addition, the prevalence of low literacy was lower in this study than what is usually seen in the primary care setting, which could have biased the results. The short follow-up time also prevented the researchers from determining whether the improvements in self-management behaviors would be sustainable among the LHL group.

White, Wolff, Cavanaugh and Rothman (2010) performed a cross-sectional study of 200 subjects with diabetes. The researchers evaluated the relationship between numeracy skills and 
food label understanding. The study found that patients with low health literacy or poor numeracy skills were significantly more likely to misunderstand or incorrectly interpret the information on food labels.

To expand the initial literature review, another search of current articles was conducted that specifically looked for articles that focused on diabetes in WV or in the Appalachian Region. Two articles were chosen for inclusion: one a master's thesis and the other a doctoral dissertation (O’Dell, 2000 \& Stegall, 2008).

O'Dell (2000) evaluated the effect that a diabetes intervention program, Dining with Diabetes, had on nutrition knowledge, self-reported behaviors, and diabetes practices among people with and without diabetes. There were 591 participants from $15 \mathrm{WV}$ counties in the study. Of the participants, 323 had diabetes, 234 were non-diabetic, and 34 did not know their diagnosis status. A pretest-posttest design was used to determine change in nutrition knowledge and self-reported behavior changes. At the six-month follow-up, 208 participants completed the posttest portion of the study.

The results show that $35 \%$ of the participants who completed the pretest also completed the posttest. Of these, $54.7 \%$ had diabetes, $39.6 \%$ did not have diabetes, and $5.7 \%$ did not know if they had diabetes or not. The majority of the participants at posttest were between 51-80 years of age $(M=74.1 \%)$.

Analysis of the data showed no significant difference in nutrition knowledge between participants who had diabetes compared to those who did not have diabetes on the overall pretest-posttest comparison. However, participants with a diagnosis of diabetes were found to improve their nutrition knowledge on posttest after completing the program $(p<0.03)$. This population also showed improvement in using a diabetic meal plan on the posttest $(p<0.02)$. 
The strength of the study was found in the population size. However, the attrition rate was a weakness of the study at $65 \%$. Another weakness was the study design.

A doctoral dissertation (Stegall, 2008) presented a pilot study research that had as the purpose to determine the feasibility of a nutritional education program for low income adult African-Americans with T2DM who had low education attainment. A Quasi-experimental design was used. There was pre-assignment to an experimental group or to a control group based on participants existing participation in the Racial and Ethnic Approaches to Community Health (REACH) 2010 Diabetes Coalition. The REACH programs were conducted at two sites: one site served at the experimental group and the other the control group.

The experimental group received nutrition education that was created by blending two educational programs. The first program was designed by the researcher and consisted of three classes based on the From My Pyramid to the Plate curriculum as well as three classes from the Dining with Diabetes curriculum. The control group received usual care. Both groups were administered pretest-posttests that consisted of surveys frequently used in the evaluation of knowledge, attitude, and practice related to T2DM.

Fifty-one study participants completed the pretest (29 experimental and 22 control), and 46 study participants completed the posttest ( 27 original and three new experimental and 14 original and two new control). The posttest was administered after the six weeks of nutritional education. The results suggest that the six-week education program administered to the experimental group was effective in improving health measurements by increasing selfmanagement of T2DM. The researcher identified small sample size, bias in choosing the control and experimental groups, and short duration of the intervention as limitations to the study. 
Synthesis of the literature. The literature review investigated the association of patient education with knowledge, self-management, self-efficacy, and glycemic control in adult patients with T2DM and LHL. Many of the studies demonstrated that glycemic control was directly related to health literacy (Cavanaugh et al., 2008; Osborn et al., 2009; Powell et al., 2007; Schillinger et al., 2002; Tang et al., 2008). Atak et al. (2008) found DSME interventions had a statistically significant effect on self-efficacy in patients with T2DM. In addition, a comprehensive disease management program for patients with T2DM that addressed health literacy was found to improve diabetes outcomes (Kim et al., 2004; Rothman et al., 2004). Additionally, Sarkar et al. (2006) concluded that self-management interventions focusing on selfefficacy might be valuable in helping patients with LHL in management of their disease.

Despite the many published studies, there were no articles found that specifically addressed DSME nutrition program for adults with T2DM and LHL in rural WV. However, two documents were found that recommended further research specifically addressing these issues (O’Dell, 2000 \& Stegall, 2008). Based on a synthesis of the relevant literature, it is the assumption, with the use of the IPM, a DSME nutrition program for adult patients with T2DM and LHL in rural WV, participants will gain confidence in making more healthful food choices; increase their intake of fruits, vegetables, and healthy fat; and have improved glycemic control.

\section{Capstone Project Description}

For adults with T2DM in rural WV, a program designed to help them understand and change one aspect of diabetes self-management may make a difference in their overall health. In addition, the literature shows, people with LHL are at higher risk of developing diabetes complications. Furthermore, the IPM has been used successfully to improve glycemic control in people with diabetes and LHL. Therefore, a DSME nutritional intervention, using the IPM in one 
rural clinic in WV, shows promise of improvement of diabetes self-management for adults with T2DM and LHL.

\section{Stakeholders}

The stakeholders for this capstone project include patients with T2DM. Other stakeholders include people who do not know they have diabetes, and people who will develop diabetes in the future. However, diabetes affects not only the patient but also the patients' family members and friends. Therefore, these people are also stakeholders.

Other stakeholders include the providers and the Board of Directors at West Virginia School of Osteopathic Medicine (WVSOM) and Robert C. Byrd Clinic (RCBC). Robert C. Byrd Clinic is a 501(c) 3 not-for-profit organization. It is affiliated with WVSOM and supports the institution's mission, but has an independent Board of Directors.

Foreseen project benefits for current and future patients at RCBC with T2DM is improved glycemic control and the long-term prevention of complications through behavior change associated with DSME. For family members, prevention of T2DM complications in their loved ones is the principle focus. However, given that having a relative with diabetes is a known risk factor, lessons learned while attending the DSME program with the person with T2DM, may change behaviors in a family member such that T2DM can be prevented.

Diabetes self-management education for patients with T2DM also provides benefits for those who provide their health care. For those patients referred to the DSME program, the providers want to know that their patients with T2DM will improve their glycemic control through self-management skills learned in the program; and if the program would be appropriate for all of their patients with diabetes. With a successful program, patient referrals from outside providers will most likely increase, thus increasing the short-term and long-term financial benefit 
of the project. This aspect of the project is of particular interest to the Board of Directors and administration of RCBC and WVSOM.

\section{Timeline}

The capstone project timeline was proposed to begin April 15, 2011 and complete by May 2012. However, due to events that were out of this author's control, the timeline had to be altered. Completion of the project is slated for May 2013. (See time line in Appendix C.)

\section{Resources}

Personnel, technical and financial resources were needed to conduct this capstone project. This author performed the majority of the project responsibilities. Assistance was needed for clerical duties (reception, telephone assistance, copying, etc.), and to assist participants if needed (direction to the bathrooms, use of telephone, etc.). Technological resources needed include a computer, copy machine, media projector, screen, and white board. Financial resources were needed to purchase paper, the IPM deco-foam placemats, instructor's kit, and IPM PowerPoint CD. Key budgetary items include equipment and supplies.

The capstone project was held in the Patient Education Conference Room at RCBC. The clinic administration granted the use of the conference room for the purpose of the project as an in-kind contribution. The conference room is equipped with a media projector, screen, white board, seating, and tables. Rest room facilities are located nearby. In-kind contribution was also given for the reproduction of non-copyright materials and documents on the facilities copy machines. This author purchased supplies including copy paper, stapler, staples, notebooks, and pencils with money given to her through her father's estate. The IPM trainer and teaching materials were purchased from Idaho Plate Method, LlC. (See Appendix D for the final capstone budget.) 


\section{Participants}

Participants for the project were recruited from the RCBC, Lewisburg, WV. Site approval was obtained from the clinic's administration and WVSOM. (See Appendix E for RCBC site approval; see Appendix F for WVSOM site approval). Lewisburg is located in Greenbrier County, which is on WV's Southeast border to Virginia. The US Census Bureau identifies the county as rural with 35 people per square mile and no metropolitan or micropolitan areas (US Census Bureau, 2013).

Robert C. Byrd Clinic provides medical services for people of Greenbrier and the surrounding counties in WV and VA. As of April 27, 2011, 26,884 adults (defined as persons 18 years and older) were active patients at RCBC. Of this number, 1,861, or 6.9\%, had a diagnosis of T2DM as identified by one of the International Classification of Diseases, $9^{\text {th }}$ Revision (ICD9,2011 ) codes for T2DM of 250.00 through 250.93 as one of the first four diagnostic billing codes from a search of the RCBC electronic medical record (Intergy EHR ${ }^{\mathrm{TM}}$ SAGE Software Healthcare, Inc., Version 5.50.02.05, 2007). To obtain a sample population of 30 participants for the project, patients age 18 years and older at RCBC with T2DM were invited to participate in the DSME project through recruitment posters, healthcare provider recruitment, and written invitations.

\section{Objectives}

The IPM teaching program was chosen in the implementation of the project. Permission to use the program was obtained from the University of Idaho. (See Appendix G for IPM permission document.) The project was approved by the WVU Institutional Review Board (IRB) and the WVSOM IRB. The WVU IRB was the IRB of Record. (See Appendix H for IRB approval documents.) 
The objectives for the project were:

1. Using the IPM, 51\% of adult patients with T2DM and LHL who complete the project will achieve success in their diabetes self-management as evidenced by improved 3-month follow-up posttest scores on the Food Choices Questionnaires in relation to intake of fruits, vegetables, and fatty foods.

2. At the three-month follow-up evaluation, $51 \%$ of the participants who complete the DSME program will demonstrate added confidence in making healthy food choices as demonstrated by improved posttest Food Choices Questionnaire confidence scores.

3. After completion of the diabetes education program, $51 \%$ of the adults with T2DM with LHL in rural WV will demonstrate improved glycemic control, as evidenced by improved HbA1c at the three-month follow-up.

\section{Methods}

\section{Project Design}

This practice change project used a convenience sample pretest-posttest program evaluation design. The pretest-posttest design compares data collected before and after an intervention to evaluate change because of the intervention (Designing quantitative studies, 2008). The one-group pretest-posttest design is often found in research where an education intervention is being evaluated (Archuleta et al., 2012; Sullivan-Bolyai, Bova, Lee, \& Johnson, 2012; DeWalt et al., 2009).

\section{Inclusion Criteria}

Inclusion criteria for the Capstone project was adults, age 18 years and older, with a clinical diagnosis of T2DM, the ability to speak and understand the English language, no significant cognitive impairments, and patients at RCBC. Exclusion criteria included children 
and adolescents with type 1 or T2DM; adults with type 1 diabetes; those who did not speak or could not understand the English language; patients with significant cognitive impairments; and those persons who were not patients of the clinic. It was determined in consultation with a statistician that a convenience sample of 30 subjects would provide enough data points to indicate a moderate effect of the practice change on the measured variables.

\section{Project Description}

The IPM helps patients with diabetes choose foods from five basic food groups: vegetables, starches or breads, meat or protein, fruits, and dairy. The IPM is simple to follow. There are no complicated measurements, calculations, or exchanges to learn. The method has been shown to be a successful tool in teaching older patients with T2DM how to follow prescribed medical nutrition therapy (Pederson et al., 2007; Kicklighter, 1991).

Idaho Plate Method, LLC has teaching materials available for the IPM nutrition program. A "teacher's kit," PowerPoint (PP) compact disc, and IPM placemats can be purchased from the online store. Other materials needed for the DSME program are available from the IPM website as free downloads. (See Appendix I for PP Script; see Appendix J for copy of placemat.)

Consistent portions of vegetables, starches, proteins, dairy, and fruits are key to the success of the program, and are determined by using 1-cup and 1/2 - cup measures and a nine inch dinner plate. To help participants follow the program, a placemat imprinted with a divided "plate," fruit, and dairy is the main tool used to teach the program. The placemats are colorfully illustrated with a breakfast menu on one side and lunch-dinner menu on the opposite. Program participates eat three meals per day plus a bedtime snack following the IPM guidelines, How to use the Idaho Plate Method for Diabetes Meal Planning. The booklet is available from the IPM 
website, www.platemethod.com, as a free download. The readability of the booklet is at the Flesch-Kincaid Grade Level 5.0. (See Appendix K for booklet.)

The IPM program has a food diary that is available as a free download from the program website. These were also made available to the participants. However, the food diaries were for the use of the participants only. (See Appendix L for food diary.)

Daily intake of fruits, vegetables and fats in managing dietary intake before and after the education program was evaluated with the Wilcoxon Signed Rank Test. The Wilcoxon test was also used to assess the relationship between confidence and eating behaviors. Finally, $\mathrm{HbAlc}$ levels before and three months after the education program was compared using a paired t-test analysis.

To obtain the necessary participants for the study, flyers were posted in the waiting areas of RCBC asking for adult patients with $\mathrm{T} 2 \mathrm{DM}$ to participate in a free nutritional education program. (See Appendix M for flyer.) Providers at RCBC were also asked to mention the program to their adult patients with T2DM. Those who were interested in the project were gave a copy of the flyer and directed to call a listed telephone number for additional information. Upon contacting the investigator, the project was explained to interested patients.

Three months after the start of the capstone program, there were less than half of the participants needed for the project. Therefore, with IRB approval, letters were mailed to all patients at $\mathrm{RCBC}$ with an $\mathrm{HbAlc}$ of $\geq 9.0$. After this mailing, the needed number of participants was obtained. (See Recruitment Letter for Capstone project in Appendix N.)

Informed consent was obtained from potential participants who voiced an interest in participating in the project. The informed consent was read to people by the investigator to ensure understanding of the project, willingness to participate in the project, and an 
understanding of their rights and responsibilities as a project participant. After the informed consent was signed, the participant's information was sealed in a numbered envelope. The sealed envelope was placed in a secure location.

In addition to obtaining the informed consent, all participants were screened with the Brief Patient Health Literacy Screen (BHLS). (See Appendix O.)The BHLS has been compared to the s-TOFHLA, and has been found to be a valid and reliable instrument in measuring health literacy (Sand-Jecklin \& Coyle, 2010). The BHLS is a five-question instrument that assesses the confidence of completing medical forms, reading health or medical forms, understanding health information both written and verbal, and recall of instructions given by a health care provider. The instrument is scored using a Likert-scale that assesses confidence in completing medical forms, and frequency for the remainder of the questions. The possible score on the screen ranges from five to 25. A score $<19$ indicates LHL (K. Sand-Jecklin, personal communication, March 7, 2013). The BHLS also asks the respondent to reply to a question regarding their desire for help in understanding and remembering health information. The form was read to all participants by the evaluator and the participants responses were documented verbatim.

To determine participants' ability to make healthful dietary selections, pretest-posttest food choices questionnaires were administered. The validity and reliability of food choice and food frequency questionnaires in diet intervention research has been well-documented (Thompson et al., 2002; Subar et al., 2001; Kristal, Shattuck, \& Williams, 1994). The tools chosen for this project were the Food Choices Questionnaire 1 (FCQ1) and the Food Choices Questionnaire 2 (FCQ2). (See Appendix P for FCQ1; see Appendix Q for FCQ2.) The FCQ1 includes four sections: demographics, diabetes, eating behavior, and confidence. Questions in the demographics, diabetes, and confidence sections were initially developed as a pilot evaluation of 
the Meals Made Easy for Diabetes, The Oregon Diabetes Program (Greenberg, 2005). The program was implemented in 2001 by the Oregon Diabetes Prevention and Control Program in collaboration with the Oregon State University Extension Service (Kemple, 2003). The pilot study was found to improve confidence and satisfaction of a DSME program that taught healthy meal planning using the IPM (Greenberg, 2005).

The FCQ2 has three sections: eating behavior, confidence, and patient satisfaction. The eating behaviors were duplicated from the FCQ1. Therefore, pretest-posttest scores could be compared to determine if improved food choices and confidence in making better food choices occurred after following the IPM nutrition program for three months. The patient satisfaction section aided the evaluator in determining the strengths and weaknesses of the program as interpreted by the participants.

At the beginning of the project, the FCQ1 was administered as a pretest. The Flesch Reading Ease score for the FCQ1 is 82.8 with a Flesch-Kincaid Grade Level of 3.5. The FCQ1 was read to any patients who had difficulty reading the instrument, and respondent's answers were documented on the form.

At the three-month follow-up, the FCQ2 was used as the posttest. The Flesch Reading Ease score for the FCQ2 is 84.3 with a Flesch-Kincaid Grade Level of 3.7. As with the FCQ1, for those patients who had difficulty reading the questionnaire, assistance was provided.

The program was taught using the IPM teaching program. There were nine lesson plans each 10-20 minutes in length, for a total of 120 minutes of instruction. Lesson 1 allowed for individual introductions. Lesson 2 was an introduction to the IPM. Lessons 3 through 7 taught about the food groups (vegetables, proteins, starches, dairy, and fruits). Lesson 8 taught food exchanges using the plate method. Lesson 9 summarized the program. Following the education 
program, participants completed a program evaluation form. (See Appendix S for Program Evaluation Form.)

Participants followed the program for three months. During that time, each participant was contacted by the investigator via telephone approximately six weeks after completing the education program. Telephone conversations followed a pre-written script. (See Appendix T for Mid-Point Telephone Script.) If the participant had any problems or had any questions, these issues were addressed as necessary. After three months, the participants were contacted again via a scripted telephone call, and reminded to return to the clinic for follow-up. (See Appendix U for End of 3-Month Telephone Script.) At the follow-up visit, the participant read and answered or the investigator read the FCQ 2 to the participant, and answered the questions on the questionnaire verbatim. If the participants were unable to return to the clinic for follow-up, the investigator attempted to contact the participant on the telephone and read the FCQ 2 over the phone, answering the questions on the questionnaire verbatim.

Upon obtaining the participant's informed consent, the medical record was accessed to obtain the most recent $\mathrm{HbAlc}$. A letter was sent to the participant's healthcare provider informing them that their patient was participating in the project. (See Appendix V for Provider Notification Letter.) If an $\mathrm{HbAlc}$ had not been obtained within six months prior to the beginning to the education program, the participant's provider was asked to order the laboratory test with a repeat $\mathrm{HbAlc}$ be drawn three months from that date. After three months, the follow-up HbAlc was obtained from the participant's medical record for pre-post analysis.

\section{Results}


After the three-month follow-up was completed, the data was analyzed. IBM ${ }^{\circledR}$ SPSS $®$ Statistics 20.0 Software was used for all data analysis. An alpha level of .05 was used for all statistical tests.

Demographics. Thirty patients with T2DM consented to participate in the project. All of the participants completed the BHLS and the FCQ $1(N=30)$. However, of those who agreed to participate, two did not return for the DSME program, and three-month follow-up data was not available for six others. Therefore, final data was collected on $22(73 \%)$ of the participants with an attrition rate of $27 \%$.

The majority of the project participants were female $(N=20,67 \%)$ and Caucasian $(N=26$, $87 \%)$. Four participants were Black (13\%). The average age of the participants was 61 years (range 39-77 years). In addition, the mean age at diabetes diagnosis was 54 years (range 31-77 years). The majority of the participants either had never received diabetes education $(N=10$, $33 \%)$ or had received DSME within the previous two to five years $(N=10,33 \%)$. All but one participant had a high school diploma ( $M=14$ years, range 11-17 years). Sixty percent of the participants chose or bought their own food $(N=18$, spouse 11 , family member 1$)$, and $67 \%$ of the participants prepared their own food $(N=20$, spouse 9 , family member 1$)$.

The Brief Patient Health Literacy Screen. All participants completed the BHLS. A score less than 19 indicated a limitation in health literacy $(N=8,27 \%)$, and a score of 19-25 indicated adequate health literacy $(N=22,73 \%)$. Responses to the individual questions indicated that seven (23\%) lacked confidence in filling out medical forms independently. Four (13\%) needed help from a family member or a staff member at the clinic or hospital to read health or medical forms to them. Seven participants (23\%) had problems learning about their health because of trouble understanding written health information. Six participants (20\%) had trouble 
understanding what their doctor, nurse, or pharmacist told them about their health or health treatments. Approximately one-third $(\mathrm{N}=9,30 \%)$ of the participants had trouble remembering instructions given to them by their healthcare provider after they got home. In response to the question, "What would help you best understand and remember the information you are getting about your health?" participants comments included "note taking,' 'using plain talk,' 'simple,' and "talk English."

Education Program Evaluation. The Education Program Evaluation was completed by the 28 participants who attended the nutrition self-management program. They rated program components based on a scale from very unsatisfied to very satisfied. All participants who completed the program evaluation form were very satisfied with location of the program, the time allotted for questions and discussion, and the instructor's knowledge of the IPM subject material. Most were very satisfied with the helpfulness of the instructor and others in ensuring their understanding of the program $(N=27,96 \%)$, amount of material covered $(N=25,89 \%)$, visual-aides used $(N=23,82 \%)$, and the meal planning skill learned in the program $(N=22$, $79 \%)$. However, only $13(46 \%)$ were very satisfied with the IPM in general.

Not all of the participants answered two of the questions on the program evaluation. Likeliness they would participant in other education programs offered at RCBC was answered by 27. Of these, $59 \%(N=16)$ were very likely to do so. Twenty-four participants answered the question regarding helpfulness of others in the clinic, with the majority of those very satisfied ( $N$ $=21,88 \%$ ).

Idaho Plate Method Evaluation. At the 3-month follow-up, participants $(N=22)$ were asked how many days they ate breakfast (B), lunch (L), and dinner (D) over the previous week and how often they used the IPM for the meals eaten. The majority of the participants ate three 
meals per day over the previous week $(\mathrm{B}, N=19,86 \% ; \mathrm{L}, N=21,95 \% ; \mathrm{D}, N=22,100 \%)$. Of the meals eaten, the majority also used the IPM in their meal planning $(\mathrm{B}, N=14,74 \%$;,$N=$ $18,86 \% ; \mathrm{D}, N=17,77 \%)$.

Evaluation of Food Choices. To determine if participants of the nutritional selfmanagement project who had T2DM and LHL had improved intake of fruits, vegetables, and fatty foods, the participants' responses on the FCQ1 were compared to the responses made on the FCQ2 $(N=22)$. The majority of the participants $(51.9 \%)$ showed overall improvement on the FCQ2 when compared to the FCQ1. To determine responses to the individual questions on the questionnaires, a Wilcoxon test was conducted to evaluate whether the participants had significant increased consumption of fruits and vegetables and a decreased consumption of fatty foods.

There were five questions on the questionnaires related to fruit intake. Of those, one showed a significant change. Reported fruit intake not including juice, increased significantly ( $\mathrm{z}$ $=-1.98, p 0.05)$.

Questions related to vegetable intake numbered three. The intake of vegetables, not potatoes or salad, was significantly increased after the education program $(z=-2.58, p .01)$. There was no significant difference in green salad intake or the intake of baked, boiled, or mashed potatoes.

In regards to fat intake, there were 14 questions. Significant differences were noted in five of the questions. There was a significant increase in intake of skim milk, with $\mathrm{z}=-2.094$, p.04. There was a significant decrease in the consumption of French-fries and fried potatoes $(z=-2.26, p .02)$ after the education program. Participants added significantly less butter or margarine on bread or pancakes after the education program $(z=-2.494, p .01)$ as well as less 
regular fat beef or pork hot dogs $(z=-2.693, p<0.01)$. Finally, respondents reported a significant decrease in total fat consumed $(z=-2.50, p .01)$.

Evaluation of Confidence. Self-report confidence in making healthy food choices was measured by comparing scores on a five-question confidence questionnaire that was administered before the education program and again at the three-month follow-up. Overall, all participants $(100 \%)$ had improved confidence in the selection of healthy foods. A Wilcoxon test was conducted on the individual questions to evaluate whether the participants showed increased confidence in their ability to make more healthful food choices. Participants reported significantly greater ability to prepare or share food with people who do not have diabetes $(z=-$ $3.10, p .002)$; to choose appropriate foods when hungry $(z=-2.72, p .006)$; to eat smaller meal portions at dinner $(z=-2.46, p .014)$; and to add less fat than a recipe calls for $(z=-2.10, p .035)$.

Evaluation of Glycemic Control. To determine if the majority of the participants who participated in the diabetes education program could improve their glycemic control, paired t-test analysis was used to compare the HbA1c results before and three-months after the participants were taught how to use the IPM during the nutritional self-management program. Pretest and posttest data was available for 25 of the participants. Overall, $68 \%(N=14)$ of the participants had improved HbA1c levels $\geq 0.5 \%$. However, analysis of the data shows there was very nearly a significant difference between the HbAlc pretest $(M=7.96, S D=1.83)$ and posttest $(M=7.34$, $S D=1.60), t(24)=2.02, p 0.055$. There was no significant difference found in glycemic control when comparing pre-post HbA1c for those who had not had prior diabetes education $(N=6 ; t(5)$ $=.667, p .534)$ and those who had had prior diabetes education $(N=19 ; t(18)=1.93, p .07)$ although this result was nearly statistically significant. There was also no significance found in 
patients who had adequate health literacy between pre-HbAlc levels $(M=8.05, S D=1.86)$ and post-HbA1c levels $(M=7.23, S D=1.66), t(16)=1.90, p .075)$.

\section{Summary, Discussion and Implications}

\section{Summary}

The purpose of this project was to determine if a DSME nutrition program using the IPM could help patients with T2DM and LHL in rural WV make changes in their meal plan that would positively affect their lives. The goals of the program were to determine if $51 \%$ of the participants could make better food choices, have more confidence in making food choices that affect their diabetes, and improve their HbA1c. A one-group pretest-posttest design was used to determine if the capstone project objectives were accomplished.

Objective 1. A comparison of the pretest-posttest FCQ found that $51.9 \%$ of the participants who completed the Capstone project improved their intake of fruits, vegetables, and fats. There was no significant difference found in pretest-posttest data of participants with LHL verses adequate health literacy. However, the food choices were significant with the health literacy variable removed.

The IPM encourages four servings of vegetables, three servings each of fruits and dairy, three to six servings of starches, breads, or grains, and limited fat intake per day. At the 3-month follow-up, the data showed that significantly more participants chose fruit over juice. There was also a significant increase in vegetable consumption, not counting potatoes or salads.

The most significant changes were made in relation to fat intake. Participants significantly increased their intake of skim milk in comparison to whole milk and two-percent milk. They ate significantly less French-fries, fried potatoes, and regular fat beef or pork hotdogs 
and added significantly less butter or margarine on bread or pancakes after the education program. Finally, participants reported a significant decrease in total fat consumed.

For the person with T2DM, any improvement in the consumption of carbohydratesfruits, vegetables, and starches - are important in lowering blood glucose that can aide in preventing long-term diabetes complications. These findings, which may not be statistically significant, are clinically significant. Of the clinically significant findings, there was an increase in fruit and fruit juice intake over the intake of fruit drinks and sodas, and less butter and margarine added to vegetables. Therefore, even though there was not a significant difference related to health literacy, the majority of participates in the capstone project achieved success in their diabetes self-management as evidenced by improved 3-month follow-up posttest scores on the FCQ 2 in relation to intake of fruits, vegetables, and fatty foods.

Objective 2. The confidence evaluation screen was used to compare participants' selfbelief they could make healthy food choices. Self-report confidence in making healthy food choices was measured by comparing scores on a five-question confidence questionnaire that was administered before the education program and again at the three-month follow-up. The results found the 22 participants $(100 \%)$ who completed the 3-month posttest confidence evaluation improved self-confidence in making healthy food choices.

Objective 3. Improved glycemic control of persons with T2DM and LHL was the impetus of the third objective for this capstone project. The participants' HbAlc values were obtained from their electronic medical records after the 3-month follow-up and compared to the $\mathrm{HbA1c}$ values obtained before they participated in the educational program. There was found to be a near significance in the difference between the pretest-posttest HbAlc averages. Even though there was not a significant difference, there was a clinical difference. As previously 
discussed, an HbA1c drop of $0.5 \%$ or more is clinically significant in the prevention of diabetes complications. The findings of this capstone project found $68 \%$ of the participants decreased their HbA1c by $\geq 0.5 \%$ at the 3-month follow-up. Therefore, this DSME nutrition program aided in glycemia improvement that can help prevent long-term diabetes complications.

Unintended Consequences. Due to the small number of participants with LHL, that variable became invalid for this capstone project. However, the data that was collected on the six participants with LHL leads this author to believe that expanding the number of participants to capture more people with LHL will produce significant results. Therefore, additional research that examines the relationship between T2DM, LHL, and diabetes complications needs to be explored.

\section{Discussion}

This capstone project sought to determine if participants living in rural WV with T2DM and LHL could make better food choices, have more confidence in choosing healthier foods, and improve their glycemic control following a DSME project using the IPM. At the outset of the project, Appalachian culture, beliefs, and attitudes had to be considered in the design of the nutrition intervention program. For the people of WV, food is a common denominator. Food is shared by families and friends wherever there is a gathering. Visitors to Appalachian homes are often asked to "sit an' have a bite"; to refuse an invitation is considered an insult. Unfortunately, with diets high in fat and low in fruits and vegetables, America's Health Rankings has consistently ranked WV as one of the unhealthiest states since 1990 (United Health Foundation, 2012). Therefore, the goals of this capstone project sought to change this behavior.

Theoretical Basis. The theoretical basis for this project was the health belief model. The model predicts that individuals with T2DM will engage in positive behavior changes if they 
believe they are at risk for developing complications from their diabetes (Hayden, 2009). The project depended on participants to volunteer for the capstone program. By volunteering, participants presented with known or perceived concerns about their susceptibility to serious diabetes complications. Modifying factors that contributed to individual perceptions regarding severe diabetes complications included knowledge of diabetes (majority had previous DSME), older age $(M=61)$, peer and reference group (association with WVSOM), education $(M=14$ years of education), and adequate health literacy. These perceptions were supposed benefits that acted as cues to action and led to participation in the project. After completion of the capstone project, the majority of the participants exhibited self-efficacy in their confidence to make healthier food choices and improvement in their glycemic control that can lessen their long-term risk of diabetes complications.

Limitations. Although this capstone project was carefully prepared, there were limitations. The first of these limitations was the study design. Using a quasi-experimental design lacks random assignment. Thus the design method may allow the study to be more practical, but this also poses threats to internal validity (Robson, Shannon, Goldenhar, \& Hale, 2001). With a one-group pretest-posttest design, the uncontrolled threats to validity include history, regression, maturation, testing, and instrumentation (Burns \& Grove, 2009). Therefore, future studies with similar questions need to utilize a more robust design.

Second, there were few participants with LHL. Most of the participants had adequate health literacy consistent with the BHLS. According to Sand-Jecklin, most volunteers for research projects have higher health literacy (Personal communication, November 9, 2011). Even so, by posting flyers in common waiting areas and having providers at RCBC encourage their patients to participate in the program, it was hopeful lower literacy patients would volunteer. 
Unfortunately, this was not the case. Therefore, similar studies should explore methods by which people with LHL could be attracted to participate in the project.

The third limitation involved time restraints. In the concept of this Capstone project, it was assumed there would be no difficulty in obtaining the necessary number of participants. However, after three months, only half of the needed participants had received the DSME. Therefore, with IRB approval, a letter was sent to all patients with T2DM at RCBC who had an HbA1c $\geq 9$ soliciting for volunteers. Overall, it took more than six months before 30 people had agreed to participate, and it was another three months before the final data was collected. These delays completely changed the time-line for completion of the capstone project. Future similar projects must review the timeline carefully, and determine if the project is feasible. Otherwise adjustments in the project may have to be made.

The forth limitation of this capstone project was the number of participants lost to followup. Thirty volunteers agreed to participate, but final data was available for 22 participants. To correct this limitation, a larger pool of participants could offset the attrition rate. In addition, collecting information from the participants who did not follow up would be valuable and should be added to future protocols.

\section{Implications}

This Capstone project was conducted at RCBC on the campus of WVSOM. The WVSOM strategic plan states, in its mission statement, that it "is dedicated to serve ... the state of West Virginia and the special health care needs of its residents..." (WVSOM, 2011). Robert C. Byrd Clinic, a National Committee for Quality Assurance recognized patient centered medical home (PCMH), shares the WVSOM strategic plan and mission statement. 
In providing care to patients with T2DM, disease management must involve the patient. In fact, diabetes care, according to the PCMH principles, should be patient-centered, patientmanaged, patient-empowered, and team-based (Bojadzievski \& Gabbay, 2011). DSME, as previously discussed, has been shown to improve diabetes outcomes.

Robert C. Byrd Clinic presently offers formal DSME to individuals and for groups, which are taught by this author. A chronic disease management education program (CDM), taught by a group of people certified in CDM education, is also offered through the clinic. The CDM provides outreach services throughout the community to people with various chronic diseases including diabetes.

This Capstone project presented one aspect of DSME. According to the AADE, DSME involves seven self-care behaviors including healthy eating, being active, monitoring, taking medication, problem solving, reducing risks, and healthy coping (AADE, 2011). The knowledge gained from this project can be incorporated into the behavior lesson on healthy eating for both the DSME programs and for the CDM programs.

According to the AADE “General Scope of Diabetes Educational/Clinical Care Activities," nurses, dieticians, and pharmacists serve as the primary providers of DSME and curriculum development (AADE, 2011). However, physicians, podiatrists, exercisephysiologists, eye care specialists, and mental health practitioners can also contribute their expertise to education programs (AADE, 2011). A team-based approach where professionals share their knowledge can provide people with T2DM more information than can be provided in the single-educator DSME programs. In addition, as a Doctor of Nursing Practice (DNP), the responsibilities of this author will be expanding, and other members of the health care team will need to become certified diabetes educators to continue the DSME programs. 


\section{Conclusion}

A program designed to help people with T2DM improve self-management of their disease is an important aspect of caring for people who suffer from the disease. With $12 \%$ of adults in WV with diabetes, DSME is important in preventing complications associated with the disease. The findings from this capstone project show that nutrition education using the IPM can improve consumption of fruits and vegetables, lessen fat intake, increase confidence in choosing diabetes-appropriate foods, and improve glycemic control of adults with T2DM. Additional research is needed to determine if the IPM would be useful for people with T2DM and LHL in rural WV.

\section{Attainment of Leadership Goals}

This capstone project has contributed to my personal leadership goals in a number of ways. I am confident in conducting a systematic review of the literature and disseminating those findings into clinical practice. I am more knowledgeable about T2DM and the many complications that occur because of this disease. I am also more aware of the problems associated with health literacy and how those problems affect understanding of health and healthcare. I believe that these attributes will enable me to continue my work in this area and contribute to the healthcare community to improve patient outcomes.

This capstone project population focus was adults in rural WV with T2DM. The project was not conducted merely for the satisfaction of completing the DNP requirements. This population is unique, not only because of the high number of people in WV with diabetes, but also because of their culture. As a healthcare provider born in the WV coalfields, I understand these people, and it was and is my goal to help them. As a West Virginian caring for West Virginians, I am trusted and respected by not only my patients, but by my peers. With this trust 
and respect, I can provide the practice leadership needed to care for my patients and my community as a DNP advanced practice nurse. 


\section{References}

American Association of Diabetes Educators. (2010). Diabetes Education Services

Reimbursement Tips for Primary Care Practice. Retrieved from

http://www.diabeteseducator.org/export/sites/aade/_resources/pdf/research/Diabetes_Edu cation_Services6-10.pdf

American Association of Diabetes Educators. (2011). AADE Guidelines for the Practice of DSME and Training. Retrieved from http://www.diabeteseducator.org/export/sites/aade/_resources/pdf/general/PracticeGuideli nes2011.pdf

American Diabetes Association. (2008). Position Statement: nutrition recommendations and interventions. Diabetes Care, 31(S1), S61-S78.

American Diabetes Association. (2011a). Position statement: standards of medical care in diabetes. Diabetes Care, 34(S1), S11-S61.

American Diabetes Association. (2011b). Type 2. Retrieved from http://www.diabetes.org/diabetesbasics/type2/?utm_source=Homepage\&utm_medium=ContentPage\&utm_content $=$ type2 \&utm_campaign $=\mathrm{TDT}$

American Diabetes Association. (2013). Standards of Medical Care in Diabetes-2013. Diabetes Care, 36(S1), S11-S66. doi:10.2337/dc13-S011

Anderson, R. M., Funnell, M. M., Nwankwo, R., Gillard, M. L., Oh, M., \& Fitzgerald, J. T. (2012). Evaluating a problem-based empowerment program for African Americans with diabetes: results of a randomized controlled trial. Ethnicity \& Disease, 15(4), 671-678.

Archuleta, M., VanLeeuwen, D., Halderson, K., Jackson, K., Bock, M. A., Eastman, W. et al. 
(2012). Cooking schools improve nutrient intake patterns of people with type 2 diabetes. Journal of Nutrition Education and Behavior, 44(4), 319-325.

doi:10.1016/j.jneb.2011.10.006

Atak, N., Gurkan, T., \& Kose, K. (2008).The effect of education on knowledge, selfmanagement behaviors and self-efficacy of patients with type 2 diabetes. Australian Journal of Advanced Nursing, 26(2), 66-74.

Baker, J. C. (2013). How to lower your A1C levels. Retrieved from http://www.dlife.com/diabetes/blood_sugar_management/testing/a1c-levels?

Basu, A., Allenson, S., McLellan, L. \& Hochhalter, A. (2012). Impact of an ADA-accredited diabetes education on healthcare utilization. Clinical Medicine \& Research, 3, PSA-35, p 159.

Benjamin, E. M. (2002). Self-monitoring of blood glucose: the basics. Clinical diabetes, 20(1), 45-47. doi:10.2337/diaclin.20.1.45

Boren, S. A., Fitzner, K. A., Panhalkar, P. S., \& Specker, J. E. (2009). Cost and benefits associated with diabetes education: a review of the literature. The Diabetes Educator, 35(1), $72-95$.

Bojadzievski, T. \& Gabbay, R. A. (2011). Patient-centered medical home and diabetes. Diabetes Care, 34(4), 1047-1053.

Bohanny, W., Wu, S. V., Liu, C., Yeh, S., Tsay, S. \& Wang, T. (2013). Health literacy, selfefficacy, and self-care behaviors in patients with type 2 diabetes mellitus. Journal of the American Academy of Nurse Practitioners. Advance online publication. doi:10.1111/1745-7599.12017

Brown, M. D., Lackey, H. D., Miller, T. K., \& Priest, D. (2001). Controlling calories-the 
simple approach. Diabetes Spectrum, 14(2), 110-112.

Burns, N. \& Grove, S. K. (2009). Quasi-experimental study designs. In The Practice of Nursing Research Appraisal, Synthesis, and Generation of Evidence ( ${ }^{\text {th }}$ ed. pp. 250-261). St. Louis, MO: Saunders.

Camelon, K. M., Hadell, K., Jamsen, P. T., Ketonen, K. J., Kohtamaki, H. M., Makimatilla, S. et al. (1998). The plate model: a visual method of teaching meal planning. Journal of the American Dietetic Association, 98(10), 1155-1158.

Cavanaugh, K., Huizinga, M. M., Wallston, K. A., Gebretsadik, T., Shintani, A., Davis, D. et al. (2008). Association of numeracy and diabetes control. Annuals of Internal Medicine, 148(10), 737-746. doi:10.1186/1478-7954-7=16.

Centers for Disease Control and Prevention. (2011a). National diabetes fact sheet: national estimates and general information on diabetes and prediabetes in the United States. Atlanta, GA: U.S. Department of Health and Human Services. Retrieved from http://www.cdc.gov/diabetes/pubs/pdf/ndfs_2011.pdf

Centers for Disease Control and Prevention. (2011b). Basics about diabetes. Retrieved from http://www.cdc.gov/diabetes/consumer/learn.htm

Centers for Disease Control and Prevention. (2012). Diabetes Report Card 2012. US Department of Health and Human Services.Retrieved from http://www.cdc.gov/diabetes/pubs/pdf/DiabetesReportCard.pdf

Centers for Medicare and Medicaid Services. (2013). Physician Fee Schedule Search Tool Retrieved from http://www.cms.gov/apps/physician-fee-schedule/overview.aspx

Coffman, M. J., Ferguson, B. L., Steinman, L., Talbot, L. A., \& Dunbar-Jacob, J. (2013). A 
health education pilot for Latino women with diabetes. Clinical Nursing Research, 22(1), 70-81.

Cortes, D. E., Millan-Ferro, A., Schneider, K., Vega, R. R., \& Caballero, A. E. (2013). Food purchasing selection among low-income, Spanish-speaking Latinos. American Journal of Preventative Medicine, 44(3S3), S267-S273. doi:10.1016/j.amepre.2012.11.012

Delanhanty, L. M., \& Heins, J. M. (2008). Tools and techniques to facilitate nutrition intervention. In A. M. Coulston \& C. J. Beushey (Eds.), Nutrition in the Prevention and Treatment of Disease (pp. 149-167). Burlington, MS: Elsevier Academic Press.

Della, L. J. (2011). Exploring diabetes beliefs in at-risk Appalachia. Journal of Rural Health, 27(1), 3-10.

Denham, S. A., Manoogian, M. M. \& Schuster, L. (2007). Managing family support and dietary routines: type 2 diabetes in rural Appalachian families. Family Systems \& Health, 25(1), 36-52.

Denham, S. A., Meyer, M. G., Toborg, M. A., \& Mande, M. J. (2004). Providing health education to Appalachia populations. Holistic Nursing Practice, 18(6), 293-301.

Designing quantitative studies. (2008). In D. F. Polit \& C. T. Beck, Nursing Research Generating and Assessing Evidence for Nursing Practice. ( $8^{\text {th }}$ ed. pp 248-285). Philadelphia, PA: Lippincott Williams \& Wilkins.

DeWalt, D. A., Davis, T. C., Wallace, A. S., Seligman, H. K., Bryant-Shilliday, B., Arnold, C. L. et al. (2009). Goal setting in diabetes self-management: taking the baby steps to success. Patient Education and Counseling, 77(2), 218-223. doi:10.1016/j.pec.2009.03.012

Feheley, C. (2013). American Diabetes Association releases new research estimating annual cost 
of diabetes at \$245 billion. American Diabetes Association Press Release, March 6, 2013. Retrieved from http://www.diabetes.org/for-media/2013/annual-costs-of-diabetes2013.html

Funnell, M. M. (2007). AADE position statement: individualization of diabetes self-management education. The Diabetes Educator, 33(1), 45-49.

Ganda, O. P. (2005). Secondary forms of diabetes. In C. R. Kahn, G. C. Weir, G. L. King, A. M. Jacobson, A. C. Moses, \& R. J. Smith (Eds.). Joslin’s Diabetes Mellitus. (14th ed., pp. 477-492). Philadelphia, PA: Lea and Febiger.

Greenberg, J. R. (2005). Meals made easy for diabetes: evaluation of a diabetes meal planning and nutrition education curriculum (Master's thesis). Retrieved from http://ir.library.oregonstate.edu/jspui/bitstream/1957/9408/1/Greenberg_Jeri_R_2005.pdf

Griffith, B. N., Lovett, G. N., Pyle, D. N. \& Miller, W. C. (2011). Self-rated health in rural Appalachia: health perceptions are incongruent with health status and health behaviors. BioMed Central Public Health, 11(229).Advance online publication. doi:10.1186/14712458-11-229

Haas, L., Maryniuk, M., Beck, J., Cox, C. E., Duker, P., Edwards, L., Fisher, E. et al. (2013). National standards for DSME and support. Diabetes Care, 36(S 1), S100-S108.

Harden-Fanning, F. (2013). Adherence to a Mediterranean diet in a rural Appalachian food desert. Rural and Remote Health, 13(2293), Retrieved from http://www.rrh.org.au Hayden, J. A. (2009). Health belief model. Introduction to Health Behavior Theory. (pp. 3144). Sodbury, MA: Jones and Bartlett.

Idaho Plate Method. (2011). Retrieved from http://www.platemethod.com/ International Classification of Disease, $9^{\text {th }}$ Revision. (2011). Free online searchable. Retrieved 
From

http://icd9cm.chrisendres.com/index.php?srchtype=diseases $\&$ srchtext $=$ diabetes + type $+2 \&$

Kaiser, L. L., Martin, A. C., Blackburn, M. L., Metz, D. L., Smith, D., Donohue, S. S. et al. (2009). Take care of your health! An extension program to prevent diabetes. Journal of Extension, 47(4). Retrieved from http://www.joe.org/joe/2009august/pdf/JOE_v47_4a5.pdf

Kemple A. (2003). Idaho Plate Method Program Evaluation. Oregon Department of Human Services, Diabetes Prevention and Control Program. Retrieved from http://public.health.oregon.gov/PH404Redirect.aspx?oldUrl=http $\% 3 \mathrm{~A} \% 2 \mathrm{~F} \% 2 \mathrm{Fpublic} \% 2$ Ehealth\%2Eoregon\%2Egov\%2FDiseasesConditions\%2FChronicDisease\%2FDiabetes\%2 FDocuments\%2FMMEWorkbook6\%2D06\%2Epdf

Kent, D., D'Eramo Melkus, G. D., Stuart, P. W., Boren, S. A., Coke, L., Winters et al. (2013). Reducing the risks of diabetes complications through diabetes self-management education and support. Population Health Management. Advance online publication. doi:10.1089/pop.2012.0020.

Kicklighter, J. R. (1991). Characteristics of older adult learners: a guide for diabetes practitioners. Journal of the American Diabetes Association, 91, 1418-1422.

Kim, S., Love, F., Quistberg, D. A., \& Shea, J. A. (2004). Association of health literacy with self-management behavior in patients with diabetes. Diabetes Care, 27(12), 2980-2982.

Koh, H. K., Brach, C., Harris, L. M., \& Parchman, M. L. (2013). A proposed 'health literate model' would constitute a systems approach to improving patients engagement in care. Health Affairs, 32(2), 357-367.

Kristal, A. R., Shattuck, A. L., \& Williams, A. E. (1994). Food frequency questionnaires for 
diet intervention research. In Proceedings of the 17th National Nutrient Database

Conference.Washington, DC, International Life Sciences Institute, p.110-125.

Lohri-Posey, B. (2006). Middle-aged Appalachians living with diabetes mellitus: a family affair. Family Community Health, 29(3), 214-220.

Marcum, C. (2008). Appalachian cultural awareness and community development. West Virginia University Extension Service. Retrieved from http://ritchie.ext.wvu.edu/r/download/23466

Nath, C. (2007). Literacy and diabetes self-management. American Journal of Nursing, 107(6), 43-49.

Nathan, D. M., Buse, J. B., Davidson, M. B., Ferrannini, E., Holman, R. R., Sherwin, R. et al. (2009). Medical management of hyperglycemia in type 2 diabetes: a consensus algorithm for the initiation and adjustment of therapy a consensus statement of the American Diabetes Association and the European Association for the Study of Diabetes. Diabetes Care, 32(1), 193-203.

National Institute for Health and Clinical Excellence. (2009). Type 2 diabetes: newer agents for blood glucose control in type 2 diabetes. Retrieved from http://www.nice.org.uk/nicemedia/live/12165/44318/44318.pdf

Norris, S., Lau, J., Smith, S., Schmid, C., \& Engelgau, M. (2002). Self-management education of adults with type 2 diabetes: a meta-analysis of the effect on glycemic control. Diabetes Care, 25(7), 1159-1171.

Nutbeam, D. (2000). Health literacy as a public health goal: a challenge for contemporary health education and communication strategies into the $21^{\text {st }}$ century. Health Promotion International, 15(3), 259-267. 
O’Dell, A. (2000). Increasing nutrition knowledge and food related behavior practices among participants in the "Dining with Diabetes" program in WV. (Master's thesis, WV University). Retrieved from http://wvuscholar.wvu.edu:8881//exlibris/dtl/d3_1/apache_media/L2V4bGlicmlzL2R0bC 9kM18xL2FwYWNoZV9tZWRpYS81MDU1.pdf

Oregon Diabetes Program. (2006). Meals Made Easy for Diabetes. Oregon Department of Human and Health Services. Oregon Diabetes Program, Oregon State University Extension Service. Retrieved from http://www.oregon.gov/DHS/ph/diabetes/docs/MMEWorkbook6-06.pdf

Osborn, C. Y., Cavanaugh, K., Wallston, K. A., White, R. O., \& Rothman, R. L. (2009). Diabetes numeracy. Diabetes Care, 32(9), 1614-1619.

Pederson, S. D., Kang, J., \& Kline, G. (2007). Portion control plate for weight loss in obese patients with type 2 diabetes mellitus. A controlled clinical trial. Archives of Internal Medicine, 167(12), 1277-1283.

Pearson, T. A., Stone, E. J., Grundy, S. M., McBride, P. E., Van Horn, L., \& Tobin, B. W. (2001). Translation of nutritional sciences into medical education: the Nutrition Academic Award Program. American Journal of Clinical Nutrition, 74 (2), 164-170.

Powell, C. K., Hill, E. G., \& Clancy, D. E. (2007).The relationship between health literacy and diabetes knowledge and readiness to take health action. The Diabetes Educator, 33(1), 144-151.

Raidl, M., Spain, K., Lanting, R., Lockard, M., Johnson, S., Spencer, M., et al. (2007).The healthy diabetes plate. Prevention of Chronic Disease [serial online]. Retrieved from http://www.cdc.gov/pcd/issues/2007/jan/06_0050.htm 
Rizor, H., Smith, M., Thomas, K., Harker, J., \& Rich, M. (1998). Practical nutrition: the Idaho plate method. Practical Diabetology, 17, 42-45.

Robson, L. S., Shannon, H. S., Goldenhar, L. M., \& Hale, A. R. (2001). Quasi-experimental and experimental designs: more powerful evaluation designs. In Centers for Disease Control Guide to Evaluating the Effectiveness of Strategies for Preventing Work Injuries: How to Show Whether a Safety Intervention Really Works. (pp. 29-42) (DHHS Publication No. 2001-119). Retrieved from http://ssmon.chb.kth.se/safebk/safetybk.pdf

Rosenstock, I. M. (1966). Part 2: Health services research I. A series of papers commissioned by the health services research study section of the U. S. Public Health Service.

Discussed at a conference held in Chicago, October 15-16, 1965. The Milbank Memorial Fund Quarterly, 44(3), 94-127.

Rothman, R. L., DeWalt, D. A., Malone, R., Bryant, B., Shintani, A., Crigler, B. et al. (2004). Influence of patient literacy on the effectiveness of a primary care-based diabetes disease management program. Journal of the American Medical Association, 292(14), 17111716.

Sand-Jecklin, K. \& Coyle, S. (2010). Development and testing of a brief health literacy scale. Presentation at the 2010 WVU/Alpha Rho Sigma Theta Tau International Research Conference, Morgantown WV, October 22, 2010.

Sarkar, U., Fisher, L., \& Schillinger, D. (2006). Is self-efficacy associated with diabetes selfmanagement across race/ethnicity and health literacy? Diabetes Care, 29(4), 823-829.

Schilllinger, D., Grumbach, K., Piette, J., Wang, F., Osmond, D., Daher, C., et al. (2002). Association of health literacy with diabetes outcomes. Journal of the American Medical Association, 288(4), 475-482. 
Sealy, Y. M., Zarcadoolas, C., Dresser, M., Wedemeyer, L., Short, L. \& Silver, L. (2012). Using public health detailing and a family-centered approach to promote patient-provider-parent action for reducing childhood obesity. Childhood Obesity, 8(2), 132-146. doi:10.1089/chi.2011.0025

Seley, J. J. \& Weinger, K. (2007). Executive summary: the state of the science on nursing best practices for diabetes self-management. American Journal of Nursing, 107(6), 73-78. doi:10.1097/01.NAJ.0000271859.76333.0e

Siminerio, L. M., Piatt, G. A., Emerson, S., Ruppert, K., Saul, M., Solano, F. et al. (2008). Deploying the chronic care model to implement and sustain diabetes self-management training programs. The Diabetes Educator, 32(2), 253-260.

Snetselaar, L. G. (2008). Nutrition intervention: lessons from clinical trials. In A. M. Coulston \& C. J. Boushey (Eds.), Nutrition in the Prevention and Treatment of Disease, (pp. 139-148). Burlington, MA: Elsevier Academic Press.

Stegall, R. L. (2008). From MyPyramid to the plate: a multifaceted nutrition intervention for African Americans with type 2 diabetes. (Doctoral dissertation, Clemson University). Retrieved from http://etd.lib.clemson.edu/documents/1211398479/umi-clemson-1679.pdf

Steiner G. (1996). The Diabetes Atherosclerosis Intervention Study (DAIS): a study conducted in cooperation with the World Health Organization. Diabetologia, 1996(39), 1665-1661.

Strychar, I., Elisha, B., \& Schmitz, N. (2012). Type 2 diabetes self-management: role of selfefficacy. Canadian Diabetes Association. Advance on-line publication. Retrieved from http://dx.doi.org/10.1016/jcjd.2012.10.005

Stohr, A. D. (2012). Diabetes and health equity in West Virginia: a review. Health Statistics 
Center West Virginia Department of Health and Human Resources. (HSC Statistical Brief No. 28). Retrieved from http://www.wvdhhr.org/bph/hsc/

Subar, A. F., Thompson, F. E., Kipnis, V., Midthune, D., Hurwitz, P., McNutt, S. et al. (2001). Comparison validation of the Block, Willett, and National Cancer Institute food frequency questionnaires: the eating at America's Table Study. American Journal of Epidemiology, 2001(154), 1089-1099.

Sullivan-Bolyai, S., Bova, C., Lee, M. \& Johnson, K. (2012). Development and pilot testing of a parent education intervention for type 1 diabetes: parent education through simulation. The Diabetes Educator, (38), 50-57. doi:10.1177/0145721711432457

Tang, Y. H., Pang, S. M. C., Chan, M. F., Yeung, G. S. P., \& Yeung, V. T. F. (2008). Health literacy, complication awareness, and diabetic control in patients with type 2 diabetes mellitus. Journal of Advanced Nursing, 62(1), 74-83.

Thompson, F. E., Subar, A. F., Brown, C. C., Smith, A. F., Sharbaugh, C. O., Jobe, J. B. et al. (2002). Cognitive research enhances accuracy of food frequency questionnaire reports: results of an experimental validation study. Journal of the American Dietetic Association, 102(2), 212-225.

Unger, J. (2007). Pathogenesis of type 2 diabetes. Diabetes Management in Primary Care. Philadelphia, PA: Lippincott Williams \& Wilkins.

United Health Foundation.(2012). Americas health rankings. Retrieved from http://www.americshealthrankings.ord/WV/2012

United States Department of Health and Human Services, Healthy People 2020. (2011).

Diabetes Overview. Retrieved from http://www.healthypeople.gov/2020/ topicsobjectives2020/overview.aspx?topicid $=8$ 
United States Census Bureau. (2010). State and County QuickFacts. Retrieved from http://quickfacts.census.gov/qfd/states/54/54025.html

United States Census Bureau. (2013). State and County QuickFacts. Retrieved from http://quickfacts.census.gov/qfd/states/54/54025.html

United States Department of Agriculture and U.S. Department of Health and Human Services. (2010). Dietary Guidelines for Americans, 2010. (7th ed.). Washington, DC: U.S. Government Printing Office.

Vernon, J. A., Trujillo,A., Rosenbaum, S. \& DeBuono, B. (2007). Low health literacy: implications for national health policy. George Washington University. Retrieved from http://www.gwumc.edu/sphhs/departments/healthpolicy/chsrp/downloads/LowHealthLite racyReport10_4_07.pdf

Wallace, L, S., Vaughn, C. J., Rogers, E. S., Rust, C. F., Devoe, J. E., \& Weiss, B.D. (2012). Use of theory in low-literacy intervention research from 1980 to 2009.American Journal of Health Behavior,36(2), 145-152.

Weir, S., Donahue, K., \& Roederer, M. (2008). Diabetes. In Philip D. Sloane, Lisa M. Slatt, Mark H. Ebell, Louis B. Jacques, \& Mindy A. Smith (Eds.), Essentials of Family Medicine (5 ${ }^{\text {th }}$ ed., pp. 227-246). Philadelphia: Lippincott.

Weiss, B. D. (2007). Removing Barriers to Better, Safer Care: Health Literacy and Patient Safety: Help Patients Understand: Manual for Clinicians. ( $2^{\text {nd }}$ ed.). Chicago, IL: American Medical Association.

West Virginia Department of Health and Human Resources. (2007). WV Diabetes Strategic Plan 2002-2007, Charleston, WV.

West Virginia School of Osteopathic Medicine. (2011). WVSOM Institutional Strategic Plan. 
Retrieved from http://www.wvsom.edu/AboutWVSOM/rcb-clinic

West Virginia University Extension Service. (2011). Dining with diabetes. Retrieved from http://dwd.ext.wvu.edu/

What is health literacy? (2004). In L. Nielsen-Bohlman, A. M. Panzer, \& D. A. Kindig (Eds.), Health Literacy a Prescription to End Confusion. (pp. 31-58).Washington, DC: National Academies Press.

White, R., Wolff, K., Cavanaugh, K. L., \& Rothman, R. (2010). Addressing health literacy and numeracy to improve diabetes education and care. Diabetes Spectrum, 23(4), 238-243.

World Health Organization. (2013). World health statistics diabetes fact sheet. (WHO Publication No. 312). Retrieved from http://www.who.int/mediacentre/factsheets/fs312/en/index.html\#

Wynne, A. L. (2007). Diabetes mellitus. In A. L. Wynne, T. M. Woo, \& A. J. Olyaei (Eds), Pharmacotherapeutics for Nurse Practitioner Prescribers. (2 ${ }^{\text {nd }}$ ed. pp. 939-964). Philadelphia, PA: F. A. Davis.

Ziemer, D., Berkowitz, D., Panoyioto, R., El-Kebbi, I., Musey, V., Anderson, L., et al. (2003). A simple meal plan emphasizing healthy food choices is as effective as an exchange-based meal plan for urban African Americans with type 2 diabetes. Diabetes Care, 26(6), 1719 1724. 
Appendix A

\section{Documentation of permission to use the health belief model}

Hello Pam,

You have our permission to use model with appropriate citation. There is no charge.

Gail Cambridge

Administrative Services Manager

Milbank Memorial Fund

Tel: $212-355-8400$

Fax: 212-355-8599

From: Pamela Edens [mailto:pedens@suddenlink.net]

Sent: Monday, April 12, 2010 11:14 AM

To: Gail Cambridge

Subject: Use of health belief model

Dear Sir or Madam:

I am a doctoral of nursing practice (DNP) student at West Virginia University, and would like to request permission to use Rosenstock, I. M. (1966). The Milbank Memorial Fund Quarterly, Vol. 44. No. 3, Part 2: Health Services Research I. A Series of Papers Commissioned by the Health services Research Study Section of the U. S. Public Health Service. pp. 94-127.

As a DNP student, I will be conducting a capstone project that must be theory based. My capstone will evaluate an education program for elderly patients with type 2 diabetes in rural Appalachia with low health literacy. The outcomes to be evaluated includes self-management and quality of life. For this study, the Health Belief Model, I believe, is a perfect "fit."

Of course I am aware there will be charges incurred for the use of the Model, and I will forward that amount to you upon your request

Thank you for this consideration.

Pam 
Appendix B

\section{Using the Health Belief Model with Adults with}

Diabetes Type 2 with LHL

Individual Perceptions

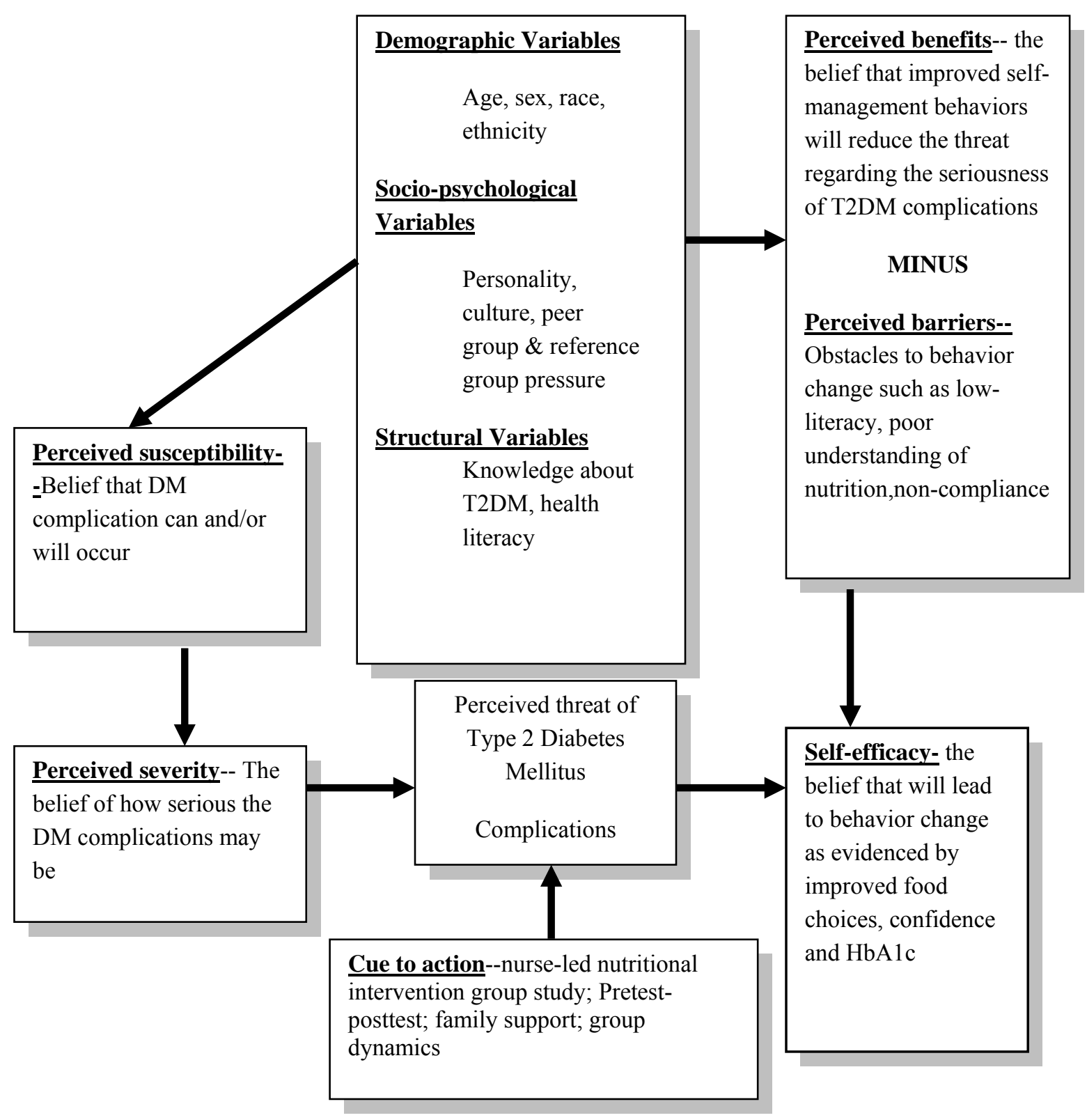


Appendix C

\section{Capstone Completion Timeline}

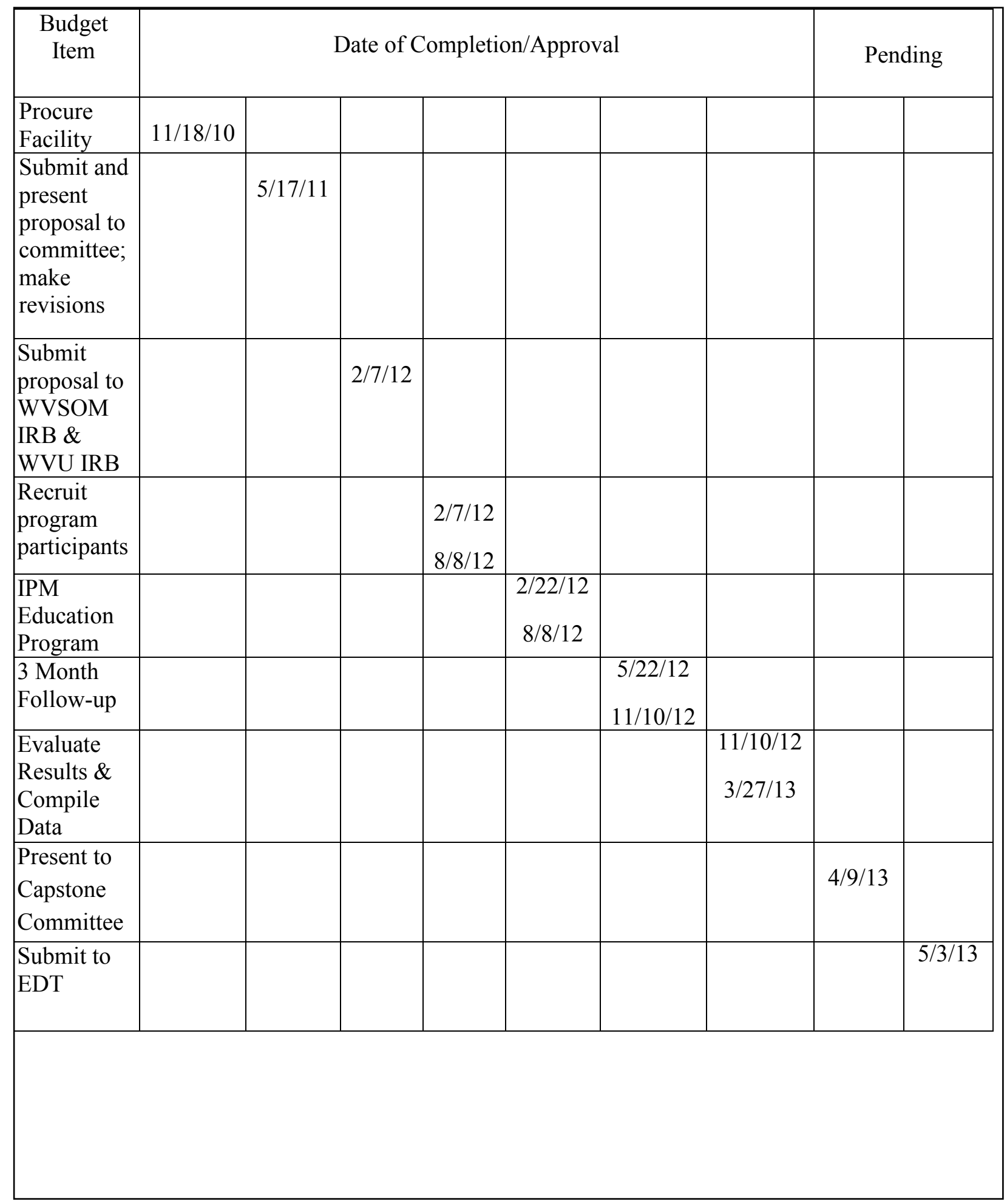




\begin{tabular}{|c|c|c|c|c|}
\hline & Budget Item & $\begin{array}{l}\text { Budget } \\
\text { Amount }\end{array}$ & $\begin{array}{l}\text { Actual } \\
\text { Cost/Time }\end{array}$ & $\begin{array}{c}\text { Budget } \\
{[+/-]}\end{array}$ \\
\hline \multicolumn{5}{|l|}{ Facilities } \\
\hline & \begin{tabular}{|l} 
RCBC Patient \\
Education Conference \\
Room
\end{tabular} & 0 & $\begin{array}{l}\text { In kind } \\
\text { contribution }\end{array}$ & 0 \\
\hline \multicolumn{5}{|l|}{ Equipment } \\
\hline & Copy machine use & & $\begin{array}{l}\text { In kind } \\
\text { contribution }\end{array}$ & 0 \\
\hline \multicolumn{5}{|l|}{ Supplies } \\
\hline \multirow[t]{9}{*}{ 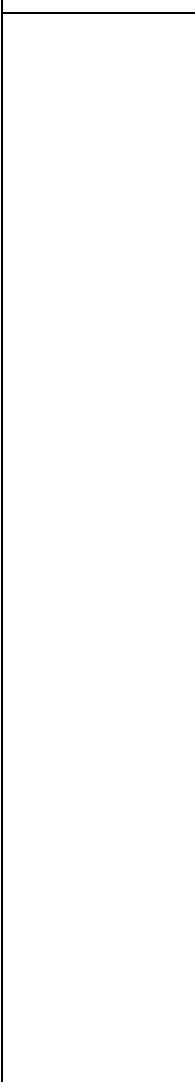 } & Booklets \# 50 & 250 & $\begin{array}{l}\text { In kind } \\
\text { contribution }\end{array}$ & 0 \\
\hline & 1 Box of paper & 50 & 31.96 & +18.04 \\
\hline & 3 Toner cartridges & 100 & $\$ 55.98$ & +44.02 \\
\hline & 1 Stapler & 20 & $\begin{array}{r}\text { In kind } \\
\text { contribution }\end{array}$ & $+\$ 20.00$ \\
\hline & 1 Box of staples & 10 & $\begin{array}{r}\text { In kind } \\
\text { contribution }\end{array}$ & +10.00 \\
\hline & 100 pens & 10 & $\begin{array}{r}\text { In kind } \\
\text { contribution }\end{array}$ & +10.00 \\
\hline & Refreshments & $\begin{array}{l}(\$ 50.00 \text { per } \\
\text { class session }) \\
\$ 400\end{array}$ & $\begin{array}{r}\text { In kind } \\
\text { contribution }\end{array}$ & +400.00 \\
\hline & Miscellaneous & 50 & 0 & +50.00 \\
\hline & \begin{tabular}{|l|} 
IPM teaching \\
materials
\end{tabular} & 300 & 288.15 & +11.85 \\
\hline Personnel & & & & \\
\hline
\end{tabular}




\begin{tabular}{|l|l|r|l|r|}
\hline & $\begin{array}{l}\text { Assistant to help } \\
\text { with clerical } \\
\text { duties }\end{array}$ & 0 & $\begin{array}{l}\text { In kind } \\
\text { contribution }\end{array}$ & 0 \\
\hline Total Budget & $\$ 1,190$ & $\$ 376.09$ & +813.91 \\
\hline
\end{tabular}




\section{Appendix E}

\section{Evidence of Capstone Site Administrative Support}
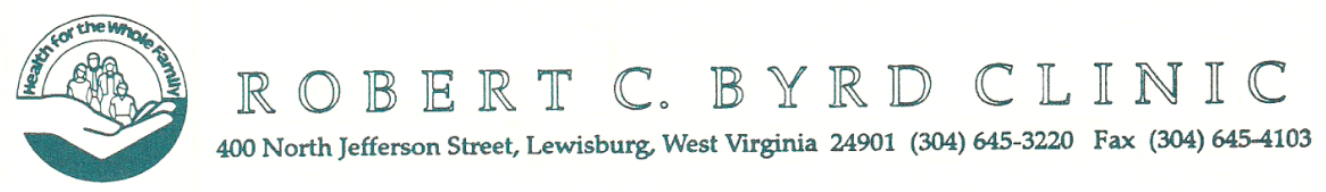

November 18, 2010

Pamela L. Edens, FNP

Robert C. Byrd Clinic

400 North Lewis Street

Lewisburg, WV 24901

Dear Pam,

This letter serves as official communication that I, as the RCBC Executive Director, authorize your capstone project of conducting an evaluation of the Idaho Plate Method as a medical nutrition tool/program in teaching patients with type 2 diabetes and low health literacy at the Robert C. Byrd Clinic.

This sounds like an exciting project and I will be interested in the outcomes. Good luck with your research.

Sincerely,

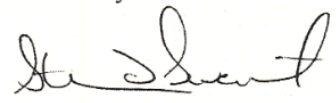

Steven L. Swart

Executive Director / CFO

WEST VIRGINIA SCHOOL OF OSTEOPATHIC MEDICINE CLINIC, INC.

- A Not For Profit Corporation • 
Appendix F

WVSOM Site Approval

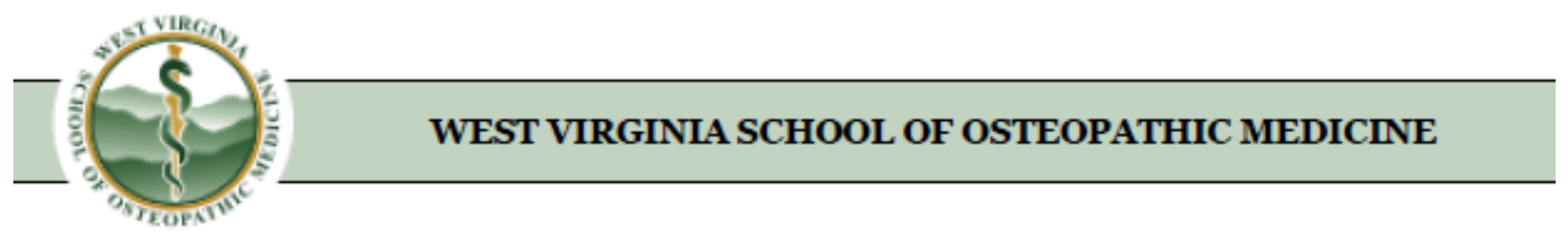

Pamela L. Edens, APRN, FNP-BC, BC-ADM

Robert C. Byrd Clinic

$400 \mathrm{~N}$. Jefferson St.

Lewisburg, WV 24901

w: (304) $645-3220 \times 261$

h: (304) 661-3903

Dear Pam,

This letter is in reference to your Capstone project to be conducted at the Robert C. Byrd Clinic, in partial fulfillment of course work at WVU. The WVSOM IRB is willing to enter into an inter-institutional agreement with WVU regarding this protocol so that the WVU IRB is the IRB of record.

Please forward the WVU IRB contact information to me and I will ensure that the paperwork gets filled out. Additionally, the WVSOM will still need a copy of the IRB approval from WVU prior to implementation of your project. Please forward this approval letter along once you have secured it.

Let me know if you have any questions.

Thanks so much,

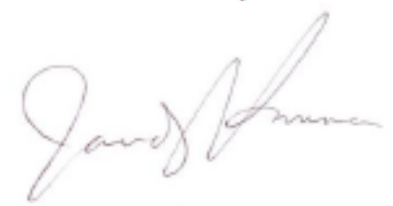

Jandy Hanna, Ph.D.

Chair, WVSOM IRB

$400 \mathrm{~N}$. Lee St.

Lewisburg, WV 24901

W: (304) 647-6366

jhanna@osteo.wvsom.edu 
Appendix G

\section{Idaho Plate Method Permission Document}

\section{Hi Pamela Edens}

We certainly give you permission to use our material in your study.

The material can not be copied or duplicated but you may use our material as a teaching tool in your study. You probably have our booklets which you can reproduce. It comes in the educator kit.

We would request you share the results of your study so we can Post it on our website.

For elderly clients I find they do best with a menu idea page on their refrigerator (it reminds them of sample meals) \& the decofoam placemat.

I use a fine point sharpie marker to write personalized instructions for each client. Example: For Miss Mable On the breakfast side: Take your Meds. Take your insulin.

Check your Blood Sugar. If above call your MD.

I am able to stop my frequent ER fliers when you give them permission/ instruction to call the $\mathrm{MD}$ before they get way out of control. Plus I See a big improvement in my clients A1C because usually the biggest Problem with elderly clients is they forget to take their medication / Insulin.

I hear of dramatic improvement with BG levels and wt, weekly from clients.

I am sure you will see the same.

If you need assistance setting up the criteria for the study you could Talk to Dining with Diabetes out of West Virginia. They do a great job Working with clients using the IPM. They also keep good statistics.

Good Luck

Kathleen Thomas RD CD LD CDE

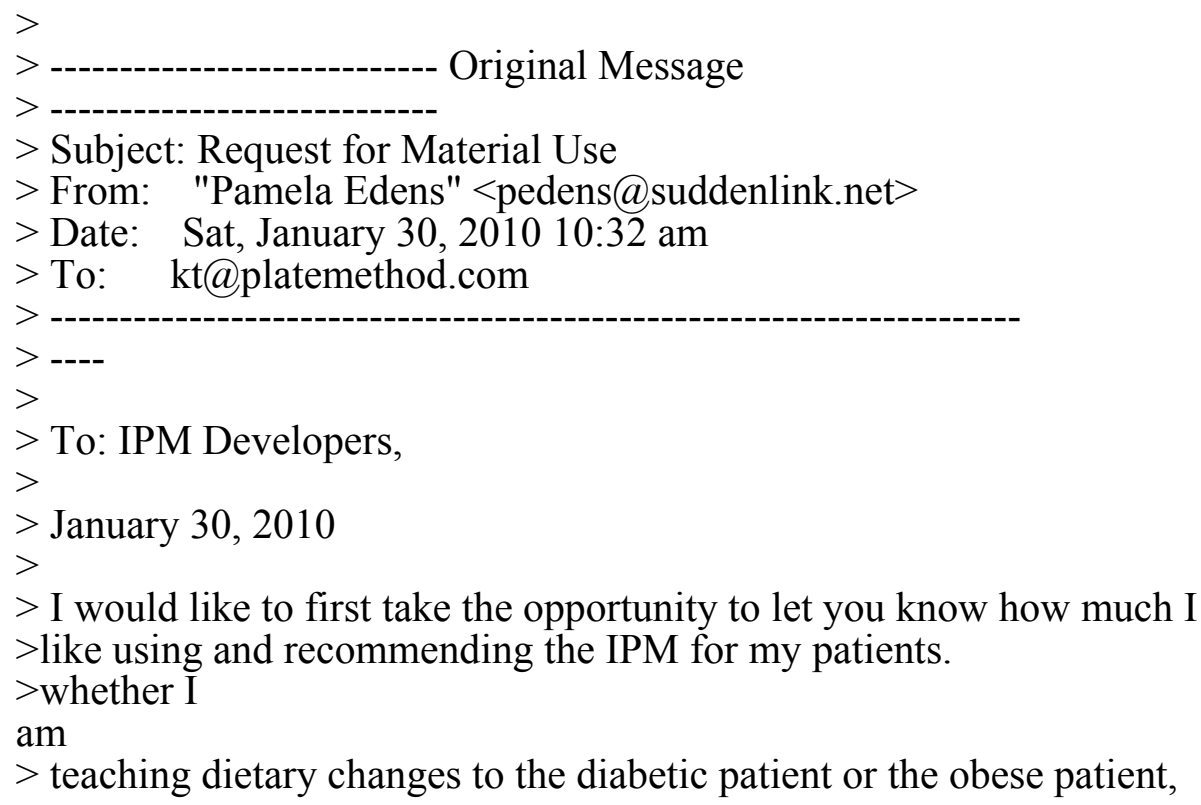


$>$ the program is simple to follow and the results are proven in results

$>$ seen by

my

$>$ patients.

$>$

$>$ Also, I am a Doctorate of Nursing Practice student at West Virginia

$>$ University. For my capstone project, I am conducting a

$>$ quasi-experimental design study of elderly type 2 diabetic patients with low health literacy.

$>$ The outcome measure of the study will look at two hour post-prandial

glucose

$>$ levels after a diabetic education program where I would like to use

$>$ the IPM as the exclusive nutritional education component.

$>$

$>$ Therefore, I am requesting permission to use your tool in my study.

$>$ You

may

$>$ contact me at the e-mail address or one of the telephone numbers below

$>$ for further information.

$>>$

> Pamela L. Edens, DNP student, APRN, FNP-BC, BC-ADM P.O. Box 981

$>$

$>1277$ Anjean Road

$>$ 


\section{Appendix $\mathrm{H}$}

\section{WVU IRB Approval Document}

\begin{tabular}{|l|c|}
\hline WestVirginiaUniversity & West Virginia University \\
& Institutional Review Board (IRB) \\
886 Chestnut Ridge Rd, PO Box 6845 \\
Morgantown, WV 26506-6845 \\
Phone: (304) 293-7073 \\
Fax: (304) 293-3098 \\
http://oric.research.wvu.edu \\
\hline
\end{tabular}

\section{IRB Authorization Agreement for an Individual Protocol}

Full Study Title: An Evaluation of the Idaho Plate Method Dietary Program for Older Adults with Type 2

Diabetes and Limited Health Literacy in Rural West Virginia.

WVU Principal Investigator(s): Pam Edens, APRN, FNP-BC, BC-ADM

Other Institution Principal Investigator: Pam Edens, APRN, FNP-BC, BC-ADM

Other Institution IRB \#: IRB00003217

Sponsor or Funding Agency, if any: NA

Award Number, if any: NA

Name of Institution Providing IRB Review: West Virginia University (IORG0000194)

OHRP Federalwide Assurance (FWA) Number: FW A00005078

IRB Registration Number: $\quad$ IRB00000315

IRB00002568

Name of Institution Relying Upon IRB Review Above (Institution B): West Virginia Sch of Osteopathic Med OHRP Federalwide Assurance (FWA) Number: FWA00007632

With respect to the individual research project specified above only, the Officials signing below agree that West Virginia Sch of Osteopathic Med__ may rely on the above IRB review, approval, and continuing oversight provided under West Virginia University's Assurance.

West Virginia Sch of Osteopathic Med retains ultimate responsibility for the protection of human subjects with respect to the research project which is the subject of this Agreement, including (I) the development and enforcement of institutional policies to ensure compliance with federal and state laws and regulations relating to human subjects research; (ii) safeguarding the rights and welfare of human subjects through active monitoring of the manner in which such research is conducted, including the continuing competency of investigators performing such research in connection with__ West Virginia Sch of Osteopathic Med_to conduct such research; (iii) educating on a continuing basis the members of its research community in order to establish and maintain a culture of compliance with federal regulations and institutional policies relating to human subjects research, and (iv) implementing such oversight mechanisms as are appropriate to ensure adherence to the determinations of WVU's IRB, including the prompt forwarding to WVU's IRB of required progress reports, adverse event reports, investigator requests for modification of approved research or related forms (including subject consent forms), and information suggesting possible deviations from IRB-approved research protocol or other concerns about the manner in which such research is being conducted. _ West Virginia Sch of Osteopathic Med_ shall cooperate fully with any request from WVU for information or documentation relating to the research proposal or the conduct of the research following IRB approval. 
WVU for information or documentation relating to the research proposal or the conduct of the research following IRB approval.

West Virginia Sch of Osteopathic Med__ understands and agrees that it shall be responsible for enforcement of determinations by WVU's IRB that the research project must be suspended or discontinued, or that specific conditions must be met in order for the research project to commence or continue.

Each party (as the "Indemnifying Party") shall indemnify and hold harmless the other party, its directors, trustees, officers, employees and agents from and against any and all liabilities, claims, costs, damages, expenses, and losses, including reasonable attorneys' fees, arising from any negligent act or omission of the Indemnifying Party or any of its employees or agents in connection with this Agreement. The indemnification obligation of this section shall survive termination of this Agreement.

Each party shall promptly inform the other party of any such claims, suit or action resulting from this Agreement. Each party shall assist the other party in investigating such claims, suits or actions.

West Virginia Sch of Osteopathic Med__ agrees to maintain comprehensive professional and general liability insurance policies in coverage amounts of not less than $\$ 3$ million per incident and $\$ 5$ million annul aggregate for each policy. Such policies shall cover all the activities of __West Virginia Sch of Osteopathic Med___ and its employees and agents in connection with the research which is the subject of this Agreement.

West Virginia Sch of Osteopathic Med__ agrees to supply to West Virginia University (IORG0000194) prior to commencement of __West Virginia Sch of Osteopathic Med___s involvement in the subject research a certificate of insurance documenting the existence of such insurance coverage. ___ West Virginia Sch of Osteopathic Med__ further agrees to provide to West Virginia University (IORG0000194) with not less than thirty (30) days advance written notice of any change in the scope or amount of such coverage.

The review, approval, and continuing oversight performed by the IRB satisfy the requirements of the HHS regulations for the protection of human subjects at 45 CFR 46, as well as the requirements of WVU's OHRPapproved Assurance.

Relevant minutes of IRB meetings shall be made available to _ West Virginia Sch of Osteopathic Med upon request. __ West Virginia Sch of Osteopathic Med___ remains responsible for ensuring compliance with (the IRB's determinations and with) the terms of its OHRP-approved Assurance.

This document should be kept on file at both institutions and must be provided to OHRP upon request.

Signatures:

Authorized Official of West Virginia University

Date:

Print Full Name: Daniel R. Vasgird, PhD

Institutional Title: Director, Office of Research Integrity \& Compliance

Authorized Official of West Virginia Sch of Osteopathic Med_ 
Authorized Official of __West Virginia Sch of Osteopathic Med

Date:

Print Full Name: __ Michael Adelman, D.O., J.D.___ Institutional Title: __President 
Appendix I

\section{Idaho Plate Method Power Point Script}

Retrieved from http://www.platemethod.com/downloads.html

Slide 1

\section{Idaho Plate Method \\ For Diabetes}

....Making Meals Simple

Kathleen Thomas RD, CD, LD, CDE

Helena Rizor, RD, CDE, MPAS, PA-C

Reviewed by Julie Harker Buck MHE, RD, LD

Slide 2

\section{Why should I change the way I eat?}

- To help control my blood sugars and cholesterol

- I feel better when I eat right

- To help my medications work better

- When I know how to follow my meal plan I will not have to cheat and feel guilty.

- To avoid the complications of diabetes

- To lose weight or limit weight gain

Slide 3

\section{Idaho Plate Method \\ Benefits}

- No weighing

- No measuring

- No expensive "Special Foods"

- Easy to learn and follow

Slide 4 
This is a 9-inch plate. Measure the area where the food will be placed. Now you have the right size plate.

The picture shows how to use a ruler to measure a plate so you are not using an Oversized plate at meals.

Slide 5

\section{Other dishes which will help you}

A small bowl like you get at restaurants for a cup of soup - It really holds 1 cup!

Slide 6

A small dish.

It should look full when it holds a $1 / 2$ cup.

Slide 7

A small glass or small coffee cup.

Pictures show a small glass and small coffee cup that equals 1 cup

Slide 8

Its easy to eat healthy when you use the right size dishes

Don't use oversized dishes, and fill them half way. You will be tempted to fill them up.

Slide 9 


\section{Now, using your 9 inch plate, we simply divide the plate like this}

Lets see how we add foods...

Shows a plate divided for the plate method meal plan

Slide 10

\section{Lets start with vegetables:}

Vegetables go on this $1 / 2$ of the plate.

For variety, try $1 / 2$ salad, and $1 / 2$ other veggie.

Some vegetables belong in the bread, starch, and grain section.

Enjoy vegetables!

They are high in vitamins, fiber, and low in calories.

Slide 11

\section{Vegetables}

- Salad Greens: lettuce, endive, romaine

- Cabbage

- Celery

- Tomatoes

- Cucumbers

- Carrots

- Green beans

- Cauliflower

- Broccoli

- Summer squash

- Artichoke

- Pea pods

- Leeks

- Asparagus 
- Onions

- Beets

- Greens: Turnip, mustard, kale

- Okra

- Peppers

- Spinach

- Cactus (no pales)

- Turnips

- Mushrooms

- Water chestnuts

- Zucchini

- Radishes

Slide 12

\section{Meat and protein foods:}

Put the serving on this $1 / 4$ th of the plate.

Shows where meat and protein foods go on the plate

It can be any meat and protein food.

Lean choices are best.

A small steak can fit here, but a large steak will not.

Slide 13

Meat and protein foods:

Step 1: Keep meat and protein foods on the 1/4th of the plate.

Step 2: Serving size $=1$ deck of cards 


\section{Meat / Protein \\ Try to use lean choices}

- Beef- hamburger, steak, roast, sliced

- Pork-chop, steak, roast, sliced

- Chicken- piece, sliced (best skinless)

- Turkey- piece, slice, sliced (best skinless)

- Fish- tuna, salmon, halibut, trout, any type

- Shellfish- shrimp, crab, lobster, clams

- Venison

- Peanut butter

- Cheese, low fat cheeses are best

May discuss other foods that fit on this section of the plate.

Slide 15

Now, lets look at breads, starches, and grains:

Ideas for the $1 / 4$ the plate

Put them on this 1/4th of the plate.

Soup \& Cold cereal: use a small bowl. It fits right on this 1/4th of the plate.

For Hot cereal Use a small dish

Slide 16

Ideas for the $1 / 4$ plate

breads, starches, and grains:

- Small tortilla

- Slice of bread

- Small roll

- Rice

- Pasta or noodles

- 5 crackers

- $1 / 2$ small bagel

- $1 / 2$ hamburger or hot dog bun

- 1 small biscuit

- 1 small muffin

- Small granola bar 
- Peas

- Potatoes: white, sweet, or Yams

- Winter squash

- Dry Beans/Peas: navy, pinto, lima beans, garbanzo, and lentils

- Corn or hominy

- Cup of soup

- Cereal

- Grits

- Pancake

May discuss other foods that fit on this section of the plate

Slide 17

\section{MILK}

Use a small coffee cup, or small glass to get the right serving size of milk.

If you do not drink milk, talk with your registered dietitian or educator about ways to add calcium to your diet.

Slide 18

Use a small dish

\section{Milk Choices}

- 1 small dish Lite ice cream

- Small dish sugar-free pudding

- 1 small dish frozen yogurt

Slide 19

Use small glass or coffee cup 
- 1 small glass milk

- 1 small glass buttermilk

- Small Sugar-free hot chocolate

- 1 small sugar-free latte

- Small fruit smoothie

- Or 1 carton Lite yogurt

May discuss other foods that fit on this section of the plate

Slide 20

\section{Fruit}

A serving of fruit is 1 small piece, like a small apple

Or use your small dish to hold fruits

When buying canned fruit, try juice packed, or Lite

Limit juice, eat fruit instead.

Juice does not fill you up.

Slide 21

For Most Fruits

Use your small dish

- Apple

- Apricots

- Banana, small

- Cherries

- Grapefruit, $1 / 2$

- Kiwi

- Mango, $1 / 2$

- Orange

- Pear, small

- Peach, small

- Fruit cocktail 
- Pineapple

- Nectarine, small

Slide 22

Use a small bowl

\section{Bigger servings of these fruits: melons \& berries}

- Strawberries

- Blueberries

- Raspberries

- Cantaloupe

- Honeydew Melon

- Watermelon

May discuss other foods that fit on this section of the

Slide 23

Lets look at meals. What's on a breakfast plate?

Breakfast is an important meal. Take time to have it every day.

- Kids who skip breakfast have lower test scores.

- People who skip breakfast tend to be heavier.

Slide 24

\section{To set up a breakfast meal:}

- $1 / 4^{\text {th }}$ plate for meat (optional)

- $1 / 4^{\text {th }}$ plate for Breads/Starches

- Small dish for fruit

- Milk, small glass

Slide 25 
Breakfast could be a glass of milk, an egg, a slice of toast, and a small bowl of strawberries. Sounds good!

Picture of a sample meal

Slide 26

Now lets see how to set up a lunch and dinner meal....

Picture shows foods that can go on the lunch and dinner meal.

Slide 27

\section{Lunch \& Dinner Meals}

- $1 / 4^{\text {th }}$ plate for Meat/Protein

- $1 / 4^{\text {th }}$ plate for Breads/Starches

- $1 / 2$ plate of Veggies

(Except vegetables which are a starch, and go on the $1 / 4^{\text {th }}$ for Breads/Starches)

- Small dish of fruit

- Milk, small glass

Slide 28

A lunch or dinner could be: a glass of milk, sliced roast beef, wild rice, mixed vegetables, and a small bowl of melon balls.

For more ideas: See Idaho Plate Method Guide, English edition

The guide has sample meals so clients see how various meals fit on the plate

Slide 29

A Mexican menu: Fajita with chicken, Mexican cheese and peppers; beans, an apple, and coffee with milk

For more ideas: See Idaho Plate Method Guide, Spanish edition 
The Spanish guide has sample meals so clients can see how common cultural foods fit on the plate.

Slide 30

\section{Now I can easily set up any meal!}

I know how to set up my breakfast, lunch and dinner meals.

Lets look at some other ways to make this even easier and more flexible.

Slide 31

\section{Basic Portion Sizes for 1/4th Plate}

- One deck of cards - 1/2 chicken breast, small pork chop, steak, hamburger patty, or fish filet

- One piece - one slice toast, or one small apple, or small banana

- One half - hamburger bun, English muffin, large banana, or grapefruit

- $1 / 2$ cup - mashed potatoes, cut up fruit, or juice

- One cup - milk, yogurt, melon, berries, or soup

Slide 32

1 Fruit $=1$ Milk = 1 Starch

In the basic serving sizes, Fruits, Milk, and Breads/Starches affect your blood sugar levels about the same amount.

These foods can be traded for each other. Trading these foods can give you more flexibility in your meals.

For example, at lunch you could trade milk for an extra piece of fruit.

Slide 33

When trading foods do not forget to enjoy all the food groups! 
Remember every food group or section of the plate has important vitamins and minerals to offer.

* Meats and Vegetables can not be traded for other foods.

Slide 34

\section{Hypoglycemia $=$ Low Blood Sugars}

You may feel shaky, clumsy, sweaty, confused or hungry. You might suddenly have blurry vision.

1. Test your blood sugar (if possible).

2. Eat "quick acting sugar" right away.

3. Examples: $1 / 2$ cup juice, or $1 / 2$ a regular soda, or 3 hard candies, or 3 glucose tablets.

4. Wait 15 minutes, then test again.

5. If still below 80 , repeat steps 2 and 3 .

6. When above 80 , eat a meal or snack within 30 minutes.

Slide 35

\section{Low blood sugar tips.... for people who take insulin or pills that cause insulin to be released}

- Juice, milk glucose tablets, and hard candies are good to use to treat a low blood sugar.

- Always carry something with you to treat a low blood sugar!

- Candy bars and cookies are high in fat and take longer to raise your blood sugar.

- Keep quick sources of sugar in your car.

- Always check your blood sugar before you drive.

Slide 36

More low blood sugar tips....

- Keep a quick source of sugar and your meter by your bedside.

- If you wake during the night and think you are low, DO NOT get out of bed. If you can, check you blood sugar. If not, drink the juice and wait 15 minutes before getting up. This can help protect you against a fall.

- Check your blood more often when you are sick. 
- Remember to wear medical jewelry to let others know you have DIABETES in case you can not tell them. It will get you the right help faster!

Slide 37

Question - My husband is a big man. Does he need more food?

Men: Add 1 extra serving of bread, starch, or grain at each meal, if desired.

Slide 38

Question - What about snacks?

- Save the fruit serving at meals and have it later as a snack.

- Men and kids might add an extra serving of fruit or milk or bread/starch as a snack

Slide 39

Question - What about desserts?

- Your fruit can be traded for a small dessert - use the small dish to help watch the serving size

- If you trade too often, you might gain weight

Slide 40

Question - I'm not a big eater. Can I eat less?

- Small eaters and kids: try eating a $1 / 4^{\text {th }}$ plate of vegetables

- Do not skip meals; it will tempt you to overeat later.

- Save the fruit as a snack for later.

- The sections of the plate do not have to be full. But try to eat about the same amount of food at each meal.

Slide 41

Question - We usually eat more meat than that. Don't we need more meat/protein?

- Most of us eat more protein and fat than we need. 
- By eating only a $1 / 4^{\text {th }}$ a plate of meat you can lose weight and lower your cholesterol.

Slide 42

Question - My husband drinks large glasses of milk and juice. Will that work?

- Often we get too many calories and carbohydrates from our drinks. Use the right size cup or glass for milk.

- Try to limit yourself to one serving with each meal. Drink water if still thirsty.

- Three glasses of milk have enough calcium and vitamin D for most adults and kids. Teens and nursing moms need four glasses a day.

- Drink more water. It is recommended that we drink 8 glasses of fluid a day.

Slide 43

\section{What about eating out?}

- Order smaller servings \& follow the plate set up.

- Share a meal with someone. It really is OK to do in most restaurants.

- Fill a to-go box with the extra food items before you begin your meal. It helps you avoid overeating.

- Buffet style restaurants encourage you to eat MORE. Not a good choice.

- Find healthy food choices at favorite restaurants so you know what to order.

Slide 44

\section{What about FATS?}

- Mayonnaise- Lite or fat free.

- Salad dressings- Lite salad dressings or fat free, always have on the side, even at home.

- Sour cream- Lite or fat free.

- Sprays, like Pam- count 1, 2, 3 \& stop spraying.

- Gravy- use fat free, make with fat free broth, and have a small amount on the side; can also use Au Jus.

Slide 45

Question - What are the best ways to cook meats? 
Grilled

- Broiled

- Baked

- Boiled

- Steamed

Try to Limit

- Fried

- Breaded

- High fat sauces

- Sautéed

Slide 46

Question - I'm following the Idaho Plate Method, what else can I do to lose weight?

The next step is to make sure the food stacked the highest on the plate is the vegetables.

Leave a space between the foods in each section. By doing this you make the serving size of foods slightly smaller.

Become more active, start slowly, and keep going.

Slide 47

\section{Increase Physical Activity}

- Activity can help you lose weight and improve your blood sugar levels.

- Current recommendations for most people are 60 minutes most days of the week.

- Ask your MD if you have any exercise restrictions.

- Physical activity may allow you and your MD to decrease your medications.

Slide 48

\section{Working Out}

- Start your physical activity program gradually. 
- First increase the length of your work out.

- Then increase the intensity.

- Activity can cause low blood sugars so know how to treat low blood sugars.

- Bring glucose tablets.

- Reward yourself for your extra effort (don't use food as a reward).

Slide 49

\section{Need more practice?}

Lets set up a breakfast meal.

Try putting favorite foods on the plate, or foods you usually have for breakfast.

This sample plate can allow the class to practice setting up breakfast meals.

\section{Slide 50}

\section{Now, we can put together a lunch and dinner meal.}

Use foods you enjoy. Try to use healthy choices.

This sample plate can allow the class to practice setting up lunch and dinner meals.

Slide 51

\section{How can I learn more?}

To learn more about your meal plan and ways to tailor it to your needs:

- Talk with a Registered Dietitian or Certified Diabetes Educator

- Remember decreased food intake and increased activity can lower your blood glucose levels. You may need less medication.

- Talk with your health professional before making changes in your diet and physical activity plan.

Slide 52

- Enjoy 


\section{-- Be Healthy}

--- Live Longer!

Slide 53

Educators:

To order Idaho Plate Method materials:

Website: www.platemethod.com

or Fax: 1-208-624-7279

or call toll free 1-800-429-7279

Remember you have more free educational material on the power point CD 
Appendix J

\section{Idaho Plate Method Placemat}

Retrieved from http:/www.platemethod.com/downloads.html

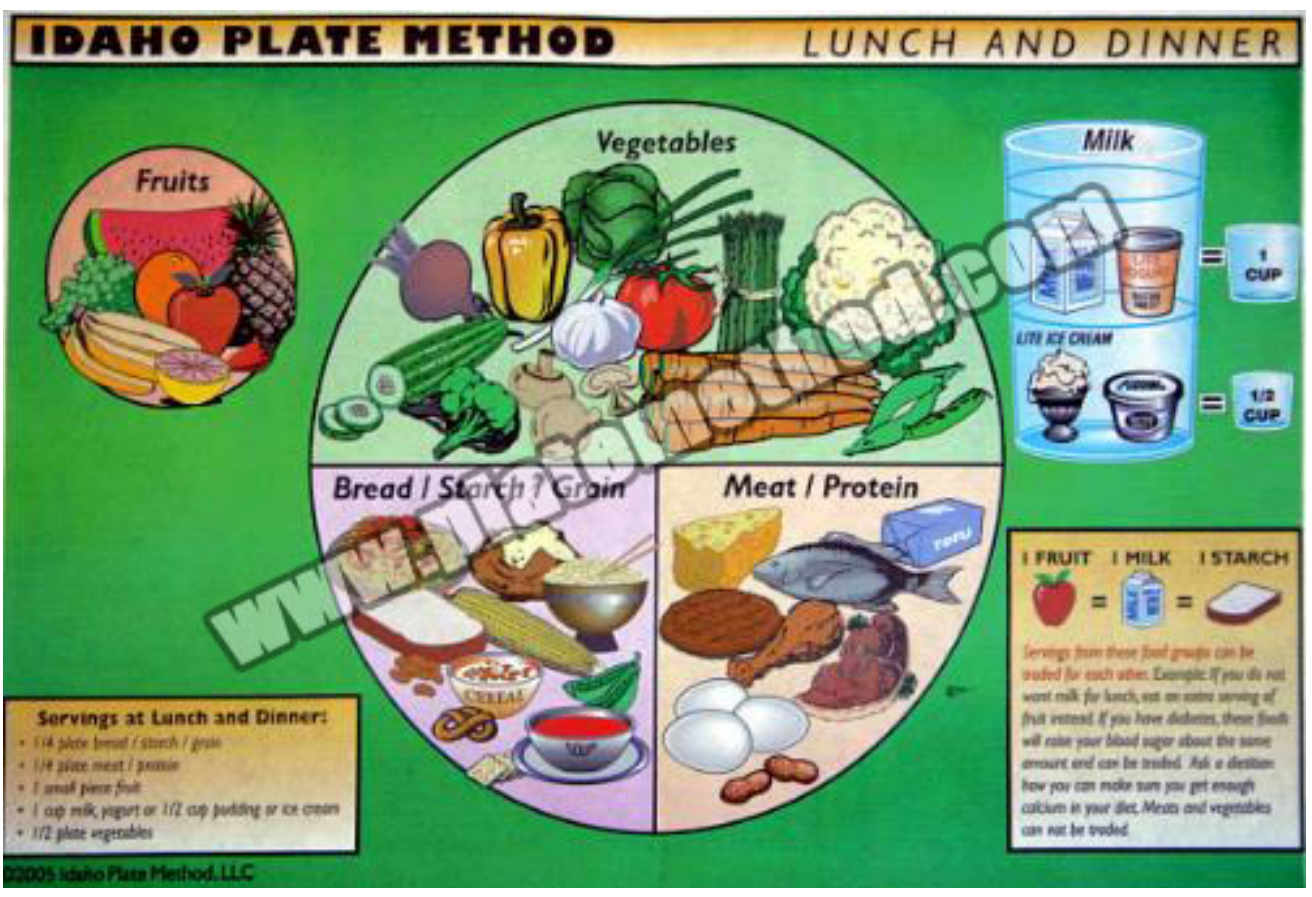


Appendix K

\section{The Idaho Plate Method Booklet}

Retrieved from http://www.platemethod.com/downloads.html

\section{What is the Idaho Plate Method?}

The Idaho Plate Method is an easy way to set up healthy meals for yourself and your family. No weighing, no carrying around measuring cups, and no expensive "Special Foods".

It can be used to help you eat healthy, lose weight, lower cholesterol, and manage your diabetes. Planning your food intake is the $1^{\text {st }}$ step in controlling your blood sugars, and diabetes. When you eat healthy you feel better and your family eats better also. It helps them learn good eating habits for life.

The Idaho Plate Method meal plan does not take the place of visiting your health Care professional.

To begin with, you need a basic plate. Guess what? Plates have gotten bigger, so the amount of food we eat has increased, and waist lines have followed.

A basic sized plate is 9 inches. Take a ruler and measure across your plate, if the part where you put your food is 9 inches across, you have the right sized plate . . if not, measure your salad plate. It may be just what you are looking for.

DO not use an oversized plate and plan on only filling it part way-you will be more tempted to overeat.

Now let's look at your bowl for cereal \& soup. A good sized bowl is the one you get a cup of soup in at a restaurant. You need a small bowl that holds about 1 cup.

Next, you need a small dish, the type you get desserts in at buffet restaurants. It holds about $1 / 2$ cup.

If you are not sure what size bowl and dish to use, use measuring cups to find out exactly how much the bowl will hold. Measure out 1 cup of dry rice (or cereal) into a bowl. If the bowl looks fairly full, it is the perfect size bowl. Now measure out $1 / 2 \mathrm{c}$ of dry rice (or cereal) into a small dish. If the dish looks fairly full it is the right size dish to use.

Now that you are using the right dishes, you are ready. Make sure and put the oversized dishes \& bowls out of sight so you do not use them again.

\section{- The hard stuff is over -}


Idaho Plate Method (IPM) Planning Form

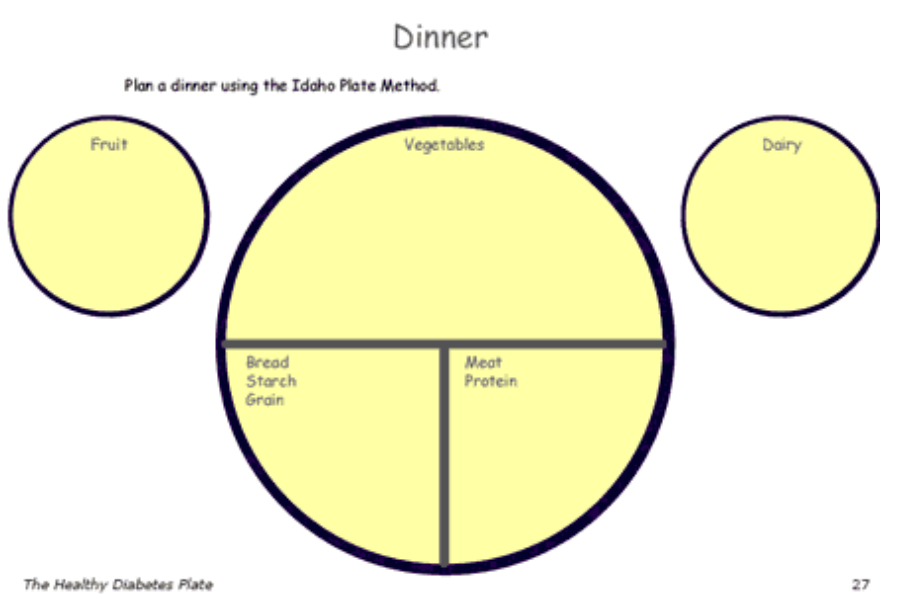

Let's look at your PLACEMAT, the side with Lunch and Dinner on it.

The pictures of foods show some examples of food you can put on each section of the plate

\section{Let's look at each part of the plate}

\section{$\underline{\text { Vegetables }}$}

Vegetables stay on this $1 / 2$ of the plate. This may be more vegetables than you are used to. That's O.K. By increasing your vegetables, you are bringing your meals back into balance and adding fiber, vitamins and minerals you might have been missing. Vegetables also help to fill you up without filing you out!

It's best not to fill the $1 / 2$ plate with only 1 veggie. You get tired of even your favorite foods that way. Try a small salad and $1 / 2$ cup of a cooked vegetable so you have more variety.

*Some vegetables are higher in starch/carbohydrate. These vegetables belong in the Bread and Starch section of the plate. Corn, Peas, Yams, Potatoes, \& Winter Squash fit in this section, not on the Vegetable Section (Winter Squash is squash that has a hard shell). So just to reviewCorn and Peas are not on the vegetable section of the Plate.

Enjoy Vegetables!

\section{$\underline{\text { Meat/Protein }}$}


This $1 / 4^{\text {th }}$ of the plate is where you put your meats. You can use any type of meat, fish, poultry, tofu, eggs, and nuts. These are high in protein, but are sometimes high in fat. Remove visible fat before cooking \& eating.

Remember, low fat foods are better for your heart and your waistline. Healthier cooking choices include baked, broiled and boiled items with little fat added. Healthier fats can be found in fish such as salmon and mackerel, and nuts (except coconut).

\section{Bread/Starch/Grain}

This $1 / 4^{\text {th }}$ of theplate is where your Breads/ Starches/ and Grains stay. You can eat a variety of foods in this group. Examples are noodles, rice, bread, cereal, crackers, small tortillas, potatoes, and dried beans (chili). For cereal and soup use the small bowl; it fits right on this $1 / 4^{\text {th }}$ of the plate. Some vegetables are higher in starch/carbohydrate. These also belong in this group and include corn, peas, yams, and winter squash.

\section{$\underline{\text { Milk }}$}

Find a small coffee cup or glass that holds about 1 cup for foods in this section. Fat Free milk, Skim milk, 1\% milk, and lite yogurt are your best choices.

Use a small dish for servings of lite ice cream and sugar-free pudding to add variety. You will need 3 servings per day from this group to get enough calcium. Teens and adolescents need 4 servings.

If you do not drink milk talk to your Registered Dietitian/ Educator about ways to add calcium to your diet. Calcium from milk products can help control blood pressure and help you lose weight easier. Calcium is also important for strong bones.

\section{$\underline{\text { Fruit }}$}

A serving of fruit is 1 small piece, like a small apple, small orange, or small orange.

Use your small dish to hold fruits like applesauce and fruit cocktail. It holds a $1 / 2$ cup. When using canned fruit, lite-packed and juice-packed are the best choices. Juice servings are about $1 / 2$ of a small coffee cup. Remember, juice does not fill you up. You will feel fuller if you eat a small orange instead of drinking juice.

Some fruits have less starch/carbohydrate, so you can eat a little more of them. These bonus foods are melons and berries, use your small bowl for the right serving size.

\section{Now you can set up Lunch \& Dinner meals}


1) You can put any meat you want on the $1 / 4^{\text {th }}$ plate for meat

2) Place any Bread/Starch food you want on the $1 / 4^{\text {th }}$ Plate for Breads

3) Any vegetable can go on the $1 / 2$ for Veggies (except starchy vegetables which go on the $1 / 4^{\text {th }}$ plate for Breads/ Starches/ Grains).

4) Any Fruit can go in the small dish for fruits.

5) Any Milk product goes in the Milk section

\section{Need ideas for more meals?}

Take a minute to look at your Idaho Plate Method placemat. They show more examples of everyday meals using your plate to set up meals. See how to use pizza and other favorite foods for a healthy meal.

\section{Now let's look at the Breakfast side of the Placemat}

1) $1 / 4^{\text {th }}$ of the plate is for meat

2) $1 / 4^{\text {th }}$ of plate for Breads / Starch / Grain

3) A dish of fruit, any kind you want

4) A milk serving.

\section{To set up a Breakfast meal}

You can choose to put any meat you want on the $1 / 4^{\text {th }}$ plate for meat.

Any Bread/Starch / Grain food you want on the $1 / 4^{\text {th }}$ plate for Breads.

Any Fruit which goes in the small dish for fruits.

Any Milk serving which goes in the Milk section.

\section{Now you know how to set upBreakfast-Lunch-\& Dinner Meals}

\section{Fruit = 1 Milk = 1 Bread $/$ Starch}

Milk, Fruits and Breads/Starches/Grains all affect your blood sugar levels about the same amount. That is why these foods can be traded for one another. So, if you do not want fruit for lunch, you could have another serving of milk. These foods each break down into sugar, a natural fuel, in the body. Maybe you are thinking you should avoid these food groups? No. You need a variety of foods from all the food groups to be healthy.

With the Idaho Plate Method you can start to control your blood sugar levels. When you eat about the same amount of food on your plate at each meal, you can help avoid blood sugar swings. It is best not to skip a food group. You need the nutrients from each food group to stay healthy. A diet low in fruits and whole grains is also low in fiber and many vitamins and minerals.

\section{You can not trade meat and vegetable servings.}

\section{What are Basic Portion Sizes?}


- 1/4th a plate, or small dish, or small coffee cup

- One deck of cards - 1/2 chicken breast, small pork chop, steak, hamburger patty, fish filet

- One piece - one slice toast, or one small apple, or small banana

- One half - hamburger bun, English muffin, large banana, or grapefruit

- 1/2 cup - mashed potatoes, cut up fruit, or juice

- $\quad$ One cup - milk, yogurt, melon, berries, or soup

\section{Need More Ideas for Meals?}

Take a minute to look at your Idaho Plate Method Guide.

Both show examples of everyday meals, including breakfast, lunch and dinners using the plate. Learn how to include pizza and other favorite foods in your meal plan.

\section{Question- What about snacks?}

Plan on saving the fruit serving at meals and have it later between meals as a snack.

\section{Question - What about desserts?}

Your fruit can be traded for a small dessert - use the small dish to help watch the serving size. If you trade too often, your weight may suffer. Also make sure the serving size of desserts is small so it does not raise your blood sugar.

\section{Question - I'm not a big eater. I can't eat that much food.}

You do not need to fill the parts of the plate top full. Remember the key is CONSISTENCY. Eat about the same amount of food on each section of the plate at each meal. If you have your favorite mashed potatoes one day, you should not have more on that section of your plate than the day when you had plain noodles. This will help you even out your blood sugars.

- For very small eaters and kids try eating $1 / 4^{\text {th }}$ plate of vegetables

- Kids may need an extra snack of fruit or bread or milk between meals

\section{Question - My husband needs more food than me?}

For men add an extra Bread/Starch/Grain serving at each meal. Just use a 2nd small dish like you use for fruits for the extra Bread /Starch/ Grain serving. You can add the extra serving between meals as a snack. Your Registered Dietitian/Educator can help you tailor the diet to your exact needs. 


\section{Question - We eat more meat than that.}

- Yes, most people eat more protein and fat than we need.

- By using only a $1 / 4^{\text {th }}$ a plate of meat you may lower your weight $\&$ cholesterol. It's the healthy thing to do!

\section{Question - My husband drinks large glasses of Milk with meals.}

- Often we get too many calories from our beverages. If he needs to lose weight, try cutting down to the smaller size of milk, or 2 small cups of milk.

- Remember to drink more water. Try at least 3 glasses a day. (Many people recommend 8 glasses of water a day).

\section{Question - What about eating out?}

- When eating out, simply order smaller servings and follow the Idaho Plate Method set up.

- Fill a to-go box with the extra food items before you begin your meal. It makes it easier to avoid over eating.

- Salad bars are a great way to get your vegetables but make sure to limit those with lots of mayonnaise. Remember potato salad and macaroni salad go on the Bread/Starch/Grain section of your plate- Not the Vegetable portion

\section{Question - What about FATS: Margarine, Salad dressings, Whip cream, Sour cream and Spray Pam ${ }^{\circledR}$ ?}

- Try to use less! Be skimpy

- Mayonnaise- Try Lite or Fat Free.

- Try Lite Salad Dressings or Fat Free; always add on the side, even at home.

- Sour Cream- Try Lite or Fat Free.

- Spray Pam ${ }^{\circledR}$ - count 1, 2, 3 \& stop Spraying.

- Gravy- use Fat Free, or use fat free broth, \& always be skimpy and serve in a small side dish. When making homemade, skim the fat off the meat broth.

Remember people with Diabetes are at a higher risk for heart attacks and strokes so try to limit fat intake, especially hard (saturated) fats. Your healthcare provider should check your cholesterol at least once a year. If you can not lower your cholesterol with your diet, it is recommended you take medication. 


\section{Question - What are the best ways to cook meats?}

- Grilled

- Broiled

- Baked

- Boiled

- Steamed

\section{Limit these methods:}

* Fried

* Breaded

* With Sauce

* Sautéed

\section{Question - I'm following the Idaho Plate Method, what else can I do to lose weight?}

Make sure the food stacked the highest on the plate is the vegetables. Do not let the foods touch each other. Example: my meat can not touch my mashed potatoes. By doing this you make the serving size of foods slightly smaller.

\section{Exercise:}

Activity affects your blood sugars and helps you use up more energy, which helps you lose weight. If you spend an afternoon working in the garden you will use more energy. You may need an extra serving of fruit or milk or bread/starch/grain to avoid problems with low blood sugar. When you are more active, make sure and check your blood sugar more often to know if you need an extra snack. It will also help to talk to your healthcare provider about cutting down on your diabetes medications when you are doing extra activity, so you can eat less without having lows.

Always carry a snack in case of hypoglycemia / low blood sugar:

- Hard candy

- Small box of raisins

- Juice box

- Glucose tablets 
Daily activity can help you control your diabetes, use less medication and lose weight. Talk to your healthcare provider before starting any exercise program. Remember - start slow. If you have little activity in your day, start with something easy:

Day 1: Try 5 minutes of walking after one meal.

Day 2: Increase to 5 minutes after 1 meal.

Day 3: Increase to 5 minutes after each meal.

Day 4: Try 7 minutes after each meal.

Day 5: Increase to 10 minutes after eachmeal.

If you are sore stay at the same time you did the day before until you feel you can advance to the next level.

If you have been inactive for a long time, walking around the perimeter of each room in your house may be a good workout for you. Remember to start slow. Try a new activity with a friend, walking, exercise class, or water aerobics. Make it fun! Remember to reward yourself for your extra effort (Not with food). A night at the movies, or a new trinket if you have been active for 7 days can be fun to look forward to.

\section{Stress:}

Stress can affect your blood sugar (BS) levels. Stress usually will cause your BS to rise.

If you are sick or have an infection your BS will usually rise, even if you are not eating much. Make sure to check BS often when sick, and drink plenty of fluids. Call your doctor if BS level is elevated. You may need to take more diabetes medication for a few days.

Remember many things out side of your control can affect BS levels. Work to maintain BS levels in normal ranges. But know you have not failed if they rise and you are doing everything you can do to keep them in normal ranges. That just means you need more help to control your BS levels.

\section{Medications:}

If you need to have diabetes medications, it is easier for your doctor to adjust your medications when your eating habits are not changing. You need to contact your healthcare provider if your BS levels are elevated. Often people will just let their Blood Sugars run high until the next visit. DON'T DO THIS!

Diagnosis: Lab testing can tell you if you have diabetes or pre-diabetes. 
Pre Diabetes is a fasting Blood Sugar level of $100 \mathrm{mg} / \mathrm{dl}$ and above. If you test above 100 you need to talk with your healthcare provider and get help with your meal plan, exercise, and maybe medication. The sooner you treat it the better off you will be.

NORMAL RANGEfor Blood Sugar is about 70-100 mg/dl.

Diabetes can be diagnosed by your healthcare provider if you have a fasting BS above $126 \mathrm{mg} / \mathrm{dl}$. *

Remember there is no such thing as a touch of sugar. Borderline diabetes means you need help and treatment.

If your health care provider has already told you that you have diabetes, make sure to ask your him or her these questions and write down the answers.

1) What should my blood sugar be before meals?

2) What should my blood sugar be 2 hours after starting a meal?

3) 2) What should my blood sugar be at Bedtime?

4) If my blood sugar is high what should I do?

5) At what High blood sugar number should I call my healthcare provider?

If you know the answers to these questions it can save you problems later. Test your blood sugar regularly with a blood sugar meter. If you do not test, you do not know what your blood sugar level is! DO NOT believe the old wives tale that I know what my blood sugar is by the way I feel!

People often say "I feel fine. My BS must be fine." Diabetes is a tricky disease. Usually people feel fine unless their BS levels are very high. When you ignore diabetes you put yourself at risk for the complications of diabetes.

- Blindness

- Kidney disease

- Nerve damage. You might feel numbness, burning, or tingling in hands or feet. Nerves to the heart, stomach and intestine, and genitals can also be affected.

- Heart disease

What can I do to take care of myself?

- Yearly eye exams - more often if recommended

- Yearly Lipid profile - shows if your blood fats are O.K.

- Yearly microalbumin - (Your healthcare provider checks urine sample for proteins). Protein in your urine can be an early warning of kidney disease.

- Yearly flu Vaccine 
- Pneumonia vaccine- every 5-7 years- as needed

- Weight- remember each pound you have needs more insulin - with diabetes you do not have enough insulin, so if you can lose weight your body needs less insulin! Even a small weight loss can really help you control your BS levels

- Foot Exam- when you visit your healthcare provider always take off your socks and ask him or her how your feet are. You can also look at your feet at home daily. Just get a cheap unbreakable camping mirror. Lay it on the floor and put your heel on the floor and look at your toes. Then put your toes on the floor and look at the heels. Report any blisters or sores to your healthcare provider immediately. Make sure to put lotion on feet daily, but not between your toes. Dry and cracking skin opens a door to letting infection in. Take good care of your feet. NEVER walk around barefoot.

- Hemoglobin A1C test

-Every 3 months if you have had a change in medication or if your blood sugars are running too high or too low.

-Every 6 months if BS levels are great.

\section{What is Hemoglobin A1C test?-}

It is a blood test. Blood can be taken from your arm or finger tip, depending on the lab test used. It measures the average BS level you have had for the last 3 months. It is a wonderful test, and really shows you your overall blood sugar control. The A1C test is usually reported to you as a percent (7\% or...). The next number on the test is your average BS level for the last 3 months. Make sure to ask your health care provider knows what your average BS level has been, since this number is most helpful to you.

HYPOGLYCEMIA - The Idaho Plate Method Guide reviews ways to treat hypoglycemia low blood sugars.

Remember to always keep small cans of juice by your bedside. If you wake up during the night shaky, sweaty, dizzy, or confused, STAY in bed. Keep your BS meter by your bedside, so you can check your BS if needed.

If your BS is low or you can not check it - drink the juice. Stay in bed for 15 minutes or so until you feel better. Check your BS again. If needed have a second can of juice.

When your BS is low, your body is not being fed and you are uncoordinated. It is easy to fall, so wait until your BS level is back to normal before walking about. Call a family member if needed to assist you.

\section{Question - How can I learn more?}

- To learn more about your meal plan and ways to tailor it to your needs: Talk with a 
Registered Dietitian or Diabetes Educator

\section{Carbohydrate Counting}

Sometimes milk - fruits - and bread/starch/grain food groups are called carbohydrate foods. Some people with diabetes count carbohydrates at each meal. That means that they get a certain number of carbohydrate foods at each meal. Using the basic Plate you have 3 servings of carbohydrate foods at each meal, which is 45 grams of carbohydrates at each meal.

All that means is that you have 1 serving of Milk and 1 serving of fruit and 1 serving of Bread/Starch/Grain at each meal.

Easy, huh?

1 Fruit = 1 Milk = 1 Bread $/$ Starch/Grain, and they all equal about 15 grams of carbohydrates, or 1 carbohydrate serving.

Remember this is extra information- it does not change anything about using the Idaho Plate Method. It is still recommended to have the right amount of each food group at each meal. If someone asks you a question about carbohydrate counting, you know what they are talking about. With the Idaho Plate Method you are doing carbohydrate counting the easy way.

I hope this information is helpful to you.

Now you have your eating back in balance.

\section{-Enjoy}

--Be Healthy

-Live Longer 


\section{The Idaho Plate Method Food Diary}

Retrieved from http://www.platemethod.com/downloads.html
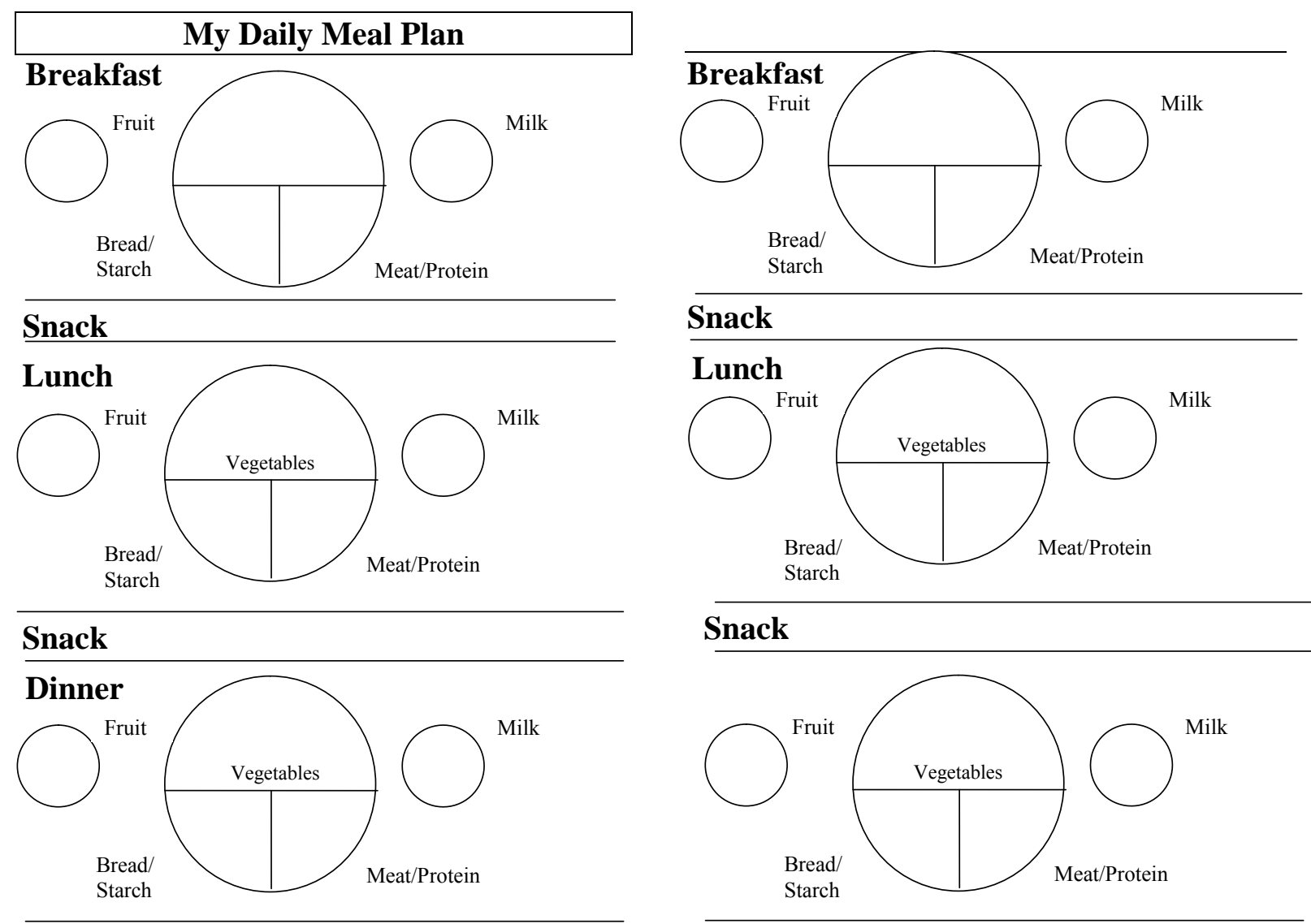

Bedtime Snack:

Activities:

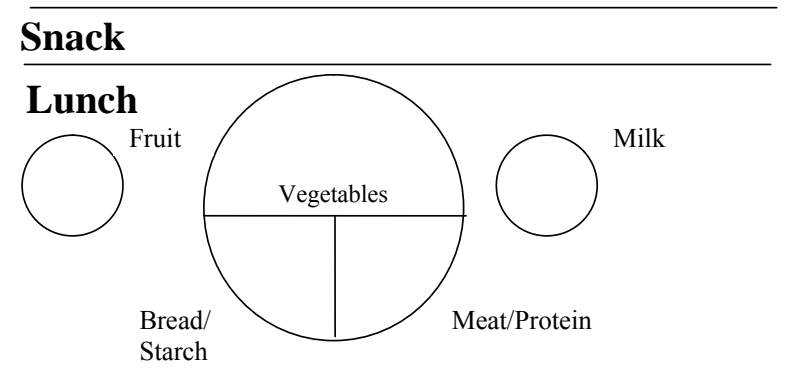

\section{Snack}

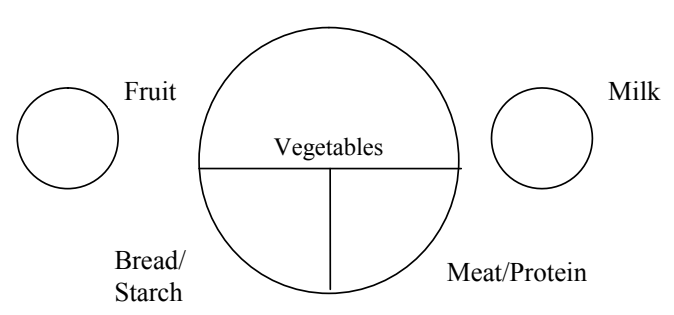

Bedtime Snack:

Activities: 
Appendix M

Patient Recruitment Flyer

\section{Adult Patients with Type 2 Diabetes Needed for Research Study}

- Do you have type 2 diabetes?

- Are you interested in learning about a simple way to follow a diabetes diet?

- Do you need to follow a diet to better control your blood sugar?

If so, please consider volunteering for this research study.

\section{Pamela Edens, MSN, APRN, FNP-BC, BC-ADM}

Student Doctorate of Nursing Practice, WVU SON

I am conducting this research study to learn more about the benefits of using a simple dietary tool for patients with type 2 diabetes at Robert C. Byrd Clinic. This research study involves answering 2 surveys before the diet teaching session, and another one 3 months after the teaching session. I will also review your blood

sugar tests that your doctor routinely does. The total time involved in participating in this research study will be approximately $3 \mathrm{hrs}$ to complete the surveys and the education program, 3 months of your commitment to follow the diet program, and $1 / 2$ hour after the 3 months to complete the final survey.

This study has been approved by West Virginia University and West Virginia School of Osteopathic Medicine. West Virginia University is the IRB of Record and West Virginia University's approval is on file.

If you are interested in being a part of this study, please contact Pamela Edens at (304) 661-3903 


\title{
Appendix N
}

\section{Patient Recruitment Letter}

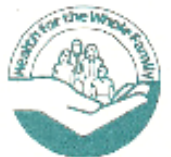

\section{WEST VIRGINIA SCHOOL OF OSTEOPATHIC MEDICINE

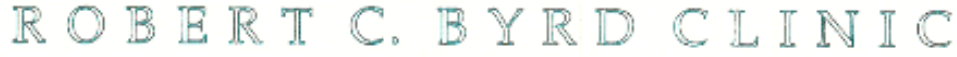
400 North Jefferson Street, Lewisburg, West Virginia 24901 (304) 645.3220 Fax (304) 645-4103

April 24, 2012

Pamela L. Edens, APRN, FNP-BC, BC-ADM

WVU Doctorate of Nursing Practice Student

Robert C. Byrd Clinic

400 N. Jefferson St.

Lewisburg, WV 24901

To:

Dear

I am one of the primary care providers at the Robert C. Byrd Clinic in Lewisburg. I am conducting a research study to learn more about the benefits of using a simple dietary tool for clinic patients with type 2 diabetes. The medical staff of Robert C. Byrd Clinic has agreed to allow me to invite all adult patients with diabetes who have had a hemoglobin Alc test result of 9 or greater to participate in my research program. Because you are a patient with type 2 diabetes who visits one the doctors or nurse practitioners at Robert C. Byrd Clinic, I am inviting you to participate in this research study.

The study involves answering 2 surveys before the diet teaching session, 1 survey after the teaching session, and another one 3 months after the teaching session. I will also review your blood sugar tests that your doctor routinely does. The total time involved in participating in this research study will be approximately 3 hrs to complete the surveys and the teaching program, and $1 / 2$ hour after the 3 months to complete the final survey. 30 people are needed for the study.

There is no charge to participate in the study. However, you may have to pay any health insurance co-pay or deductable due at the time the laboratory studies are drawn/reported. This is the same as would be for routine medical care under similar circumstances for follow up when patients are instructed on nutritional self-management of their diabetes. Being a part of this study may help you to better manage your diabetic diet.

If you are interesting in joining this study, please contact me at Robert C. Byrd Clinic at (304) 647-3220, and tell the receptionist you would like to speak with Pam Edens. She will connect you to my voice mail. Please leave me your name and telephone number. I will return your call. I look forward to hearing from you.

Sincerely,

Pamela L. Edens

\author{
WEST VIRGINIA SCHOOL OF OSTEOPATHIC MEDICINE CLINIC, INC. \\ - A Not For Profit Corporation •
}


pendix $\mathrm{O}$

Brief Patient Health Literacy Screen (BPHLS)

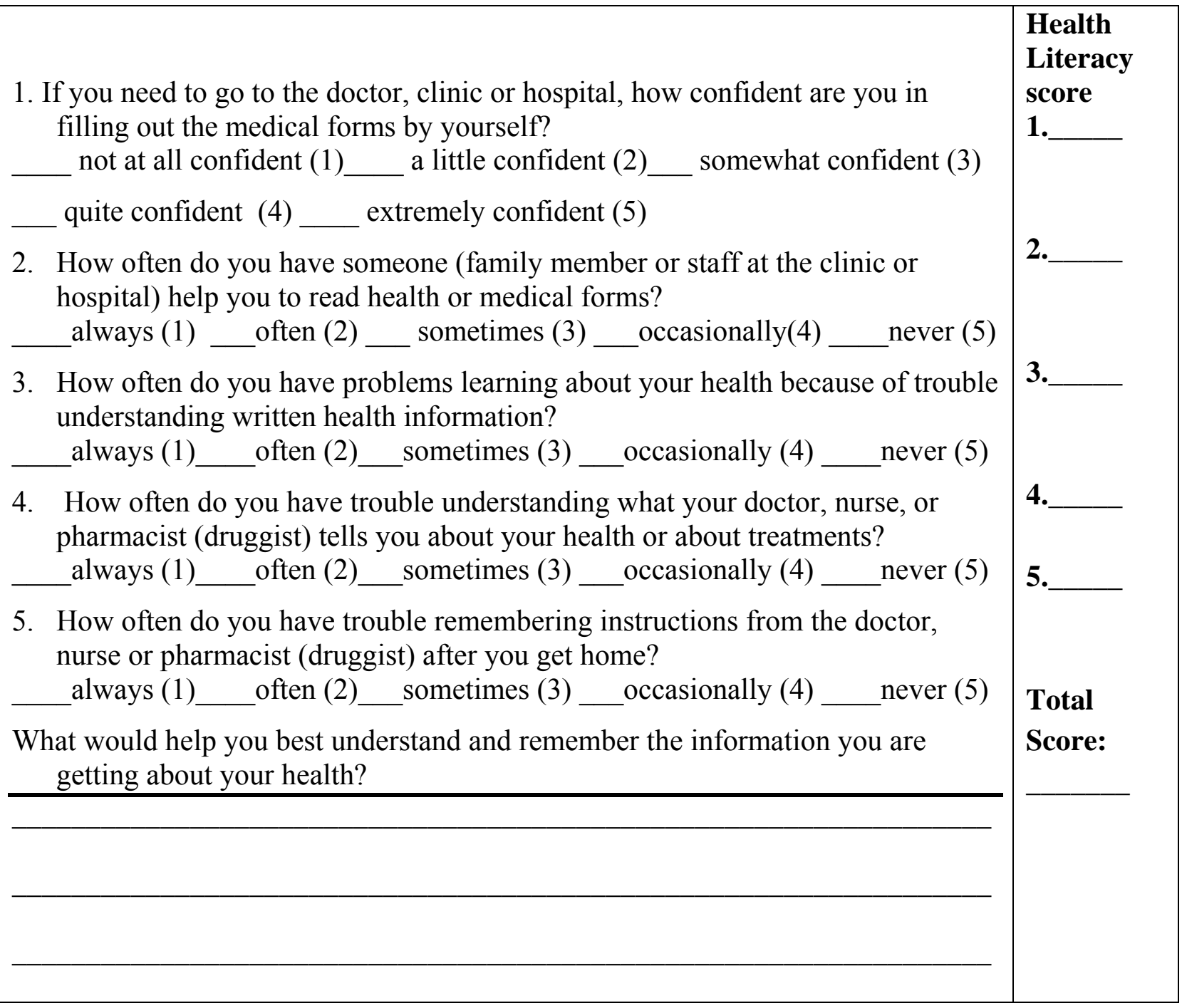

Sand-Jecklin, K. \& Coyle, S. (2010). Development and testing of a brief health literacy scale. Presentation at the 2010 WVU/Alpha Rho Sigma Theta Tau International Research Conference, Morgantown WV, October 22, 2010. 
Appendix P

\section{Food Choices Questionnaire 1}

Please answer each of the following questions by filling in the blanks or by choosing the best answer.

$$
\text { Section 1-About You }
$$

Q1. How old are you? Years

Q2. Are you: Male __ Female

Q3. Are you Hispanic or Latino? Yes No

Q4. How would you describe your race? (Check only one.) American Indian or Alaskan Native Asian or Pacific Islander Black or African American White or Caucasian other race or multiracial

Q5. What was the highest year of education that you completed? (Circle one)

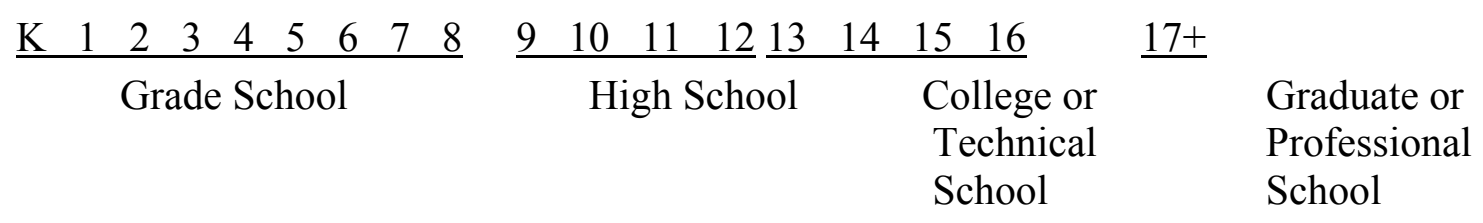

Q7. Have you ever received education about diet or meal planning by attending a series of classes, meetings, or one-on-one training with your doctor, a diabetes educator, or other health care professional? (Check one.)

Yes, within the last 6 months Yes, within the last year Yes, within the last 2 years
Yes, within the last 5 years No. I have never had a class I don't know. 


\section{Section 2-Diabetes}

Q1. How old were you when you were first told you have diabetes? Years old.

Q2. Who usually chooses or buys most of the food in your home? (Check one.) You Your husband or wife Another family member, other than your husband or wife. Your roommate or housemate.

A hired caregiver.

Someone else, please explain:

Q3. Who usually cooks most of the food eaten in your home? (Check one.) You.

Your husband or wife Another family member, other than your husband or wife. Your roommate or housemate.

A hired caregiver. Someone else, please explain: 


\section{Section 3-Eating Behavior}

The next questions give a way to think about how many servings of fruits and vegetables you usually eat. Please fill out the following questions by putting an " $\mathrm{X}$ " in the box showing how often you ate or drank each of these items of food in the past month.

Q1. 100\% Orange juice or grapefruit juice

\begin{tabular}{|l|l|l|l|l|l|l|l|l|}
\hline Never & $\begin{array}{l}1-2 \\
\text { times } \\
\text { per } \\
\text { month }\end{array}$ & $\begin{array}{l}3-4 \\
\text { times } \\
\text { per } \\
\text { month }\end{array}$ & $\begin{array}{l}5-6 \\
\text { times } \\
\text { per } \\
\text { month }\end{array}$ & $\begin{array}{l}1 \text { time } \\
\text { per day }\end{array}$ & $\begin{array}{l}2 \text { times } \\
\text { per day }\end{array}$ & $\begin{array}{l}3 \text { times } \\
\text { per day }\end{array}$ & $\begin{array}{l}4 \text { times } \\
\text { per day }\end{array}$ & $\begin{array}{l}5 \text { or } \\
\text { more } \\
\text { times } \\
\text { per day }\end{array}$ \\
\hline & & & & & & & & \\
\hline
\end{tabular}

Q2. Other $100 \%$ fruit juices (apple, grape, etc.) not counting fruit drinks or soda

\begin{tabular}{|l|l|l|l|l|l|l|l|l|}
\hline Never & $\begin{array}{l}1-2 \\
\text { times } \\
\text { per } \\
\text { month }\end{array}$ & $\begin{array}{l}3-4 \\
\text { times } \\
\text { per } \\
\text { month }\end{array}$ & $\begin{array}{l}5-6 \\
\text { times } \\
\text { per } \\
\text { month }\end{array}$ & $\begin{array}{l}1 \text { time } \\
\text { per day }\end{array}$ & $\begin{array}{l}2 \text { times } \\
\text { per day }\end{array}$ & $\begin{array}{l}3 \text { times } \\
\text { per day }\end{array}$ & $\begin{array}{l}4 \text { times } \\
\text { per day }\end{array}$ & $\begin{array}{l}5 \text { or } \\
\text { more } \\
\text { times } \\
\text { per day }\end{array}$ \\
\hline & & & & & & & & \\
\hline
\end{tabular}

Q3. Green salad (with or without other vegetables)

\begin{tabular}{|l|l|l|l|l|l|l|l|l|}
\hline Never & $\begin{array}{l}1-2 \\
\text { times } \\
\text { per } \\
\text { month }\end{array}$ & $\begin{array}{l}3-4 \\
\text { times } \\
\text { per } \\
\text { month }\end{array}$ & $\begin{array}{l}5-6 \\
\text { times } \\
\text { per } \\
\text { month }\end{array}$ & $\begin{array}{l}1 \text { time } \\
\text { per day }\end{array}$ & $\begin{array}{l}2 \text { times } \\
\text { per day }\end{array}$ & $\begin{array}{l}3 \text { times } \\
\text { per day }\end{array}$ & $\begin{array}{l}4 \text { times } \\
\text { per day }\end{array}$ & $\begin{array}{l}5 \text { or } \\
\text { more } \\
\text { times } \\
\text { per day }\end{array}$ \\
\hline & & & & & & & & \\
\hline
\end{tabular}

Q4. French fries or fried potatoes

\begin{tabular}{|l|l|l|l|l|l|l|l|l|}
\hline Never & $\begin{array}{l}1-2 \\
\text { times } \\
\text { per } \\
\text { month }\end{array}$ & $\begin{array}{l}3-4 \\
\text { times } \\
\text { per } \\
\text { month }\end{array}$ & $\begin{array}{l}5-6 \\
\text { times } \\
\text { per } \\
\text { month }\end{array}$ & $\begin{array}{l}1 \text { time } \\
\text { per day }\end{array}$ & $\begin{array}{l}2 \text { times } \\
\text { per day }\end{array}$ & $\begin{array}{l}3 \text { times } \\
\text { per day }\end{array}$ & $\begin{array}{l}4 \text { times } \\
\text { per day }\end{array}$ & $\begin{array}{l}5 \text { or } \\
\text { more } \\
\text { times } \\
\text { per day }\end{array}$ \\
\hline & & & & & & & & \\
\hline
\end{tabular}

Q5. Baked, boiled or mashed potatoes

\begin{tabular}{|l|l|l|l|l|l|l|l|l|}
\hline Never & $\begin{array}{l}1-2 \\
\text { times } \\
\text { per } \\
\text { month }\end{array}$ & $\begin{array}{l}3-4 \\
\text { times } \\
\text { per } \\
\text { month }\end{array}$ & $\begin{array}{l}5-6 \\
\text { times } \\
\text { per } \\
\text { month }\end{array}$ & $\begin{array}{l}1 \text { time } \\
\text { per day }\end{array}$ & $\begin{array}{l}2 \text { times } \\
\text { per day }\end{array}$ & $\begin{array}{l}3 \text { times } \\
\text { per day }\end{array}$ & $\begin{array}{l}4 \text { times } \\
\text { per day }\end{array}$ & $\begin{array}{l}5 \text { or } \\
\text { more } \\
\text { times } \\
\text { per day }\end{array}$ \\
\hline & & & & & & & & \\
\hline
\end{tabular}


THE NEXT QUESTIONS ASK ABOUT HOW MANY SERVINGS OF THESE FOODS YOU ATE IN THE LAST MONTH.

Q6. About how many servings of vegetables did you eat NOT counting salad or potatoes?

\begin{tabular}{|l|l|l|l|l|l|l|l|l|}
\hline Never & $\begin{array}{l}1-2 \\
\text { times } \\
\text { per } \\
\text { month }\end{array}$ & $\begin{array}{l}3-4 \\
\text { times } \\
\text { per } \\
\text { month }\end{array}$ & $\begin{array}{l}5-6 \\
\text { times } \\
\text { per } \\
\text { month }\end{array}$ & $\begin{array}{l}1 \text { time } \\
\text { per day }\end{array}$ & $\begin{array}{l}2 \text { times } \\
\text { per day }\end{array}$ & $\begin{array}{l}3 \text { times } \\
\text { per day }\end{array}$ & $\begin{array}{l}4 \text { times } \\
\text { per day }\end{array}$ & $\begin{array}{l}5 \text { or } \\
\text { more } \\
\text { times } \\
\text { per day }\end{array}$ \\
\hline & & & & & & & & \\
\hline
\end{tabular}

Q7. About how many servings of fruit did you eat NOT counting juices?

\begin{tabular}{|l|l|l|l|l|l|l|l|l|}
\hline Never & $\begin{array}{l}1-2 \\
\text { times } \\
\text { per } \\
\text { month }\end{array}$ & $\begin{array}{l}3-4 \\
\text { times } \\
\text { per } \\
\text { month }\end{array}$ & $\begin{array}{l}5-6 \\
\text { times } \\
\text { per } \\
\text { month }\end{array}$ & $\begin{array}{l}1 \text { time } \\
\text { per day }\end{array}$ & $\begin{array}{l}2 \text { times } \\
\text { per day }\end{array}$ & $\begin{array}{l}3 \text { times } \\
\text { per day }\end{array}$ & $\begin{array}{l}4 \text { times } \\
\text { per day }\end{array}$ & $\begin{array}{l}5 \text { or } \\
\text { more } \\
\text { times } \\
\text { per day }\end{array}$ \\
\hline & & & & & & & & \\
\hline
\end{tabular}




\begin{tabular}{|c|c|c|c|c|c|c|c|c|}
\hline TYPE OF FOOD & Never & $\begin{array}{c}\text { Less } \\
\text { than } \\
\text { once } \\
\text { per } \\
\text { month }\end{array}$ & $\begin{array}{c}1-2 \\
\text { times } \\
\text { per } \\
\text { week }\end{array}$ & $\begin{array}{c}3-4 \\
\text { times } \\
\text { per } \\
\text { week }\end{array}$ & $\begin{array}{c}5-6 \\
\text { times } \\
\text { per } \\
\text { week }\end{array}$ & $\begin{array}{c}1 \\
\text { time } \\
\text { per } \\
\text { day }\end{array}$ & $\begin{array}{c}2 \\
\text { times } \\
\text { per } \\
\text { day }\end{array}$ & $\begin{array}{c}3 \text { or } \\
\text { more } \\
\text { times } \\
\text { per } \\
\text { day }\end{array}$ \\
\hline Cold cereal & 1 & 2 & 3 & 4 & 5 & 6 & 7 & 8 \\
\hline $\begin{array}{l}\text { Skim milk-on cereal or to } \\
\text { drink }\end{array}$ & 1 & 2 & 3 & 4 & 5 & 6 & 7 & 8 \\
\hline $\begin{array}{l}\text { Eggs, fried or scrambled in } \\
\text { margarine, butter, or oil }\end{array}$ & 1 & 2 & 3 & 4 & 5 & 6 & 7 & 8 \\
\hline Sausage or bacon, regular fat & 1 & 2 & 3 & 4 & 5 & 6 & 7 & 8 \\
\hline $\begin{array}{l}\text { Margarine or butter on bread, } \\
\text { rolls, pancakes }\end{array}$ & 1 & 2 & 3 & 4 & 5 & 6 & 7 & 8 \\
\hline $\begin{array}{l}\text { Orange juice or grapefruit } \\
\text { juice }\end{array}$ & 1 & 2 & 3 & 4 & 5 & 6 & 7 & 8 \\
\hline Fruit (not juice) & 1 & 2 & 3 & 4 & 5 & 6 & 7 & 8 \\
\hline $\begin{array}{l}\text { Beef or pork hot dogs, } \\
\text { regular fat }\end{array}$ & 1 & 2 & 3 & 4 & 5 & 6 & 7 & 8 \\
\hline $\begin{array}{l}\text { Cheese or cheese spread, } \\
\text { regular fat }\end{array}$ & 1 & 2 & 3 & 4 & 5 & 6 & 7 & 8 \\
\hline $\begin{array}{l}\text { French fries, home fries, or } \\
\text { hash brown potatoes }\end{array}$ & 1 & 2 & 3 & 4 & 5 & 6 & 7 & 8 \\
\hline $\begin{array}{l}\text { Margarine or butter on } \\
\text { vegetables, including } \\
\text { potatoes }\end{array}$ & 1 & 2 & 3 & 4 & 5 & 6 & 7 & 8 \\
\hline Mayonnaise, regular fat & 1 & 2 & 3 & 4 & 5 & 6 & 7 & 8 \\
\hline Salad dressing, regular fat & 1 & 2 & 3 & 4 & 5 & 6 & 7 & 8 \\
\hline Rice & 1 & 2 & 3 & 4 & 5 & 6 & 7 & 8 \\
\hline $\begin{array}{l}\text { Margarine, butter, oil on rice } \\
\text { or pasta }\end{array}$ & 1 & 2 & 3 & 4 & 5 & 6 & 7 & 8 \\
\hline
\end{tabular}


Q9. Over the last month, when you prepared foods with margarine or ate margarine, how often did you use reduced-fat margarine?

$\begin{array}{lccrcc}\begin{array}{l}\text { Did not use } \\ \text { Margarine }\end{array} & \begin{array}{c}\text { Almost } \\ \text { never }\end{array} & \begin{array}{c}\text { About } 1 / 4 \text { of } \\ \text { the time }\end{array} & \begin{array}{r}\text { About } 1 / 2 \\ \text { of the time }\end{array} & \begin{array}{c}\text { About } 3 / 4 \\ \text { of the time }\end{array} & \begin{array}{r}\text { Almost all } \\ \text { or always }\end{array}\end{array}$

Q10. Overall, when you think about the foods you ate over the last month, would you say your diet was high, medium, or low in fat?

\begin{tabular}{lll} 
HIGH & MEDIUM & LOW \\
$\square$ & \\
& & \\
\hline
\end{tabular}




\section{Section 4-Confidence}

We would like to know how confident you are in doing certain activities.

For each of the following questions, please CIRCLE the number that corresponds to your confidence that you can do these tasks regularly.

Q1. How sure are you that you can follow your diet when you have to prepare or share food with other people who do not have diabetes?

$\begin{array}{llllll}\text { I know } & 1 & 2 & 3 & 4 & 5\end{array}$

Q2. How sure do you feel that you can choose the appropriate foods to eat when you are hungry (for example, snacks?)

$\begin{array}{llllll}\text { I know } & 1 & 2 & 3 & 4 & 5\end{array}$ I know I can

I cannot

Q3. How sure are you that you can stick to your healthful eating plan when you feel depressed, bored, or tense?

I know $\quad \begin{array}{llllll}1 & 2 & 2 & 3 & 4 & 5\end{array}$

I cannot

Q4. How sure are you that you can eat smaller portions at dinner?

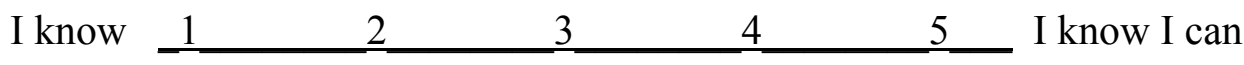

I cannot

Q5. How sure are you that you can add less fat than the recipe calls for?

I know
I cannot

THANK YOU 
Appendix Q

\section{Food Choices Questionnaire 2}

Section 1-Eating Behavior

The next questions give a way to think about how many servings of fruits and vegetables you usually eat. Please fill out the following questions by putting an " $\mathrm{X}$ " in the box showing how often you ate or drank each of these items of food in the past month.

Q1. 100\% Orange juice or grapefruit juice

\begin{tabular}{|l|l|l|l|l|l|l|l|l|}
\hline Never & $\begin{array}{l}1-2 \\
\text { times } \\
\text { per } \\
\text { month }\end{array}$ & $\begin{array}{l}3-4 \\
\text { times } \\
\text { per } \\
\text { month }\end{array}$ & $\begin{array}{l}5-6 \\
\text { times } \\
\text { per } \\
\text { month }\end{array}$ & $\begin{array}{l}1 \text { time } \\
\text { per day }\end{array}$ & $\begin{array}{l}2 \text { times } \\
\text { per day }\end{array}$ & $\begin{array}{l}3 \text { times } \\
\text { per day }\end{array}$ & $\begin{array}{l}4 \text { times } \\
\text { per day }\end{array}$ & $\begin{array}{l}5 \text { or } \\
\text { more } \\
\text { times } \\
\text { per day }\end{array}$ \\
\hline & & & & & & & & \\
\hline
\end{tabular}

Q2. Other 100\% fruit juices (apple, grape, etc.) not counting fruit drinks or soda

\begin{tabular}{|l|l|l|l|l|l|l|l|l|}
\hline Never & $\begin{array}{l}1-2 \\
\text { times } \\
\text { per } \\
\text { month }\end{array}$ & $\begin{array}{l}3-4 \\
\text { times } \\
\text { per } \\
\text { month }\end{array}$ & $\begin{array}{l}5-6 \\
\text { times } \\
\text { per } \\
\text { month }\end{array}$ & $\begin{array}{l}1 \text { time } \\
\text { per day }\end{array}$ & $\begin{array}{l}2 \text { times } \\
\text { per day }\end{array}$ & $\begin{array}{l}3 \text { times } \\
\text { per day }\end{array}$ & $\begin{array}{l}4 \text { times } \\
\text { per day }\end{array}$ & $\begin{array}{l}5 \text { or } \\
\text { more } \\
\text { times } \\
\text { per day }\end{array}$ \\
\hline & & & & & & & & \\
\hline
\end{tabular}

Q3. Green salad (with or without other vegetables)

\begin{tabular}{|c|c|c|c|c|c|c|c|c|}
\hline Never & $\begin{array}{l}1-2 \\
\text { times } \\
\text { per } \\
\text { month }\end{array}$ & $\begin{array}{l}3-4 \\
\text { times } \\
\text { per } \\
\text { month }\end{array}$ & $\begin{array}{l}5-6 \\
\text { times } \\
\text { per } \\
\text { month }\end{array}$ & $\begin{array}{l}1 \text { time } \\
\text { per day }\end{array}$ & $\begin{array}{l}2 \text { times } \\
\text { per day }\end{array}$ & $\begin{array}{l}3 \text { times } \\
\text { per day }\end{array}$ & $\begin{array}{l}4 \text { times } \\
\text { per day }\end{array}$ & $\begin{array}{l}5 \text { or } \\
\text { more } \\
\text { times } \\
\text { per day }\end{array}$ \\
\hline & & & & & & & & \\
\hline
\end{tabular}

Q4. French fries or fried potatoes

\begin{tabular}{|l|l|l|l|l|l|l|l|l|}
\hline Never & $\begin{array}{l}1-2 \\
\text { times } \\
\text { per } \\
\text { month }\end{array}$ & $\begin{array}{l}3-4 \\
\text { times } \\
\text { per } \\
\text { month }\end{array}$ & $\begin{array}{l}5-6 \\
\text { times } \\
\text { per } \\
\text { month }\end{array}$ & $\begin{array}{l}1 \text { time } \\
\text { per day }\end{array}$ & $\begin{array}{l}2 \text { times } \\
\text { per day }\end{array}$ & $\begin{array}{l}3 \text { times } \\
\text { per day }\end{array}$ & $\begin{array}{l}4 \text { times } \\
\text { per day }\end{array}$ & $\begin{array}{l}5 \text { or } \\
\text { more } \\
\text { times } \\
\text { per day }\end{array}$ \\
\hline & & & & & & & & \\
\hline
\end{tabular}

5. Baked, boiled or mashed potatoes

\begin{tabular}{|l|l|l|l|l|l|l|l|l|}
\hline Never & $\begin{array}{l}1-2 \\
\text { times } \\
\text { per } \\
\text { month }\end{array}$ & $\begin{array}{l}3-4 \\
\text { times } \\
\text { per } \\
\text { month }\end{array}$ & $\begin{array}{l}5-6 \\
\text { times } \\
\text { per } \\
\text { month }\end{array}$ & $\begin{array}{l}1 \text { time } \\
\text { per day }\end{array}$ & $\begin{array}{l}2 \text { times } \\
\text { per day }\end{array}$ & $\begin{array}{l}3 \text { times } \\
\text { per day }\end{array}$ & $\begin{array}{l}4 \text { times } \\
\text { per day }\end{array}$ & $\begin{array}{l}5 \text { or } \\
\text { more } \\
\text { times } \\
\text { per day }\end{array}$ \\
\hline & & & & & & & & \\
\hline
\end{tabular}


THE NEXT QUESTIONS ASK ABOUT HOW MANY SERVINGS OF THESE FOODS YOU ATE IN THE LAST MONTH.

Q6. About how many servings of vegetables did you eat NOT counting salad or potatoes?

\begin{tabular}{|l|l|l|l|l|l|l|l|l|}
\hline Never & $\begin{array}{l}1-2 \\
\text { times } \\
\text { per } \\
\text { month }\end{array}$ & $\begin{array}{l}3-4 \\
\text { times } \\
\text { per } \\
\text { month }\end{array}$ & $\begin{array}{l}5-6 \\
\text { times } \\
\text { per } \\
\text { month }\end{array}$ & $\begin{array}{l}1 \text { time } \\
\text { per day }\end{array}$ & $\begin{array}{l}2 \text { times } \\
\text { per day }\end{array}$ & $\begin{array}{l}3 \text { times } \\
\text { per day }\end{array}$ & $\begin{array}{l}4 \text { times } \\
\text { per day }\end{array}$ & $\begin{array}{l}5 \text { or } \\
\text { more } \\
\text { times } \\
\text { per day }\end{array}$ \\
\hline & & & & & & & & \\
\hline
\end{tabular}

Q7. About how many servings of fruit did you eat NOT counting juices?

\begin{tabular}{|l|l|l|l|l|l|l|l|l|}
\hline Never & $\begin{array}{l}1-2 \\
\text { times } \\
\text { per } \\
\text { month }\end{array}$ & $\begin{array}{l}3-4 \\
\text { times } \\
\text { per } \\
\text { month }\end{array}$ & $\begin{array}{l}5-6 \\
\text { times } \\
\text { per } \\
\text { month }\end{array}$ & $\begin{array}{l}1 \text { time } \\
\text { per day }\end{array}$ & $\begin{array}{l}2 \text { times } \\
\text { per day }\end{array}$ & $\begin{array}{l}3 \text { times } \\
\text { per day }\end{array}$ & $\begin{array}{l}4 \text { times } \\
\text { per day }\end{array}$ & $\begin{array}{l}5 \text { or } \\
\text { more } \\
\text { times } \\
\text { per day }\end{array}$ \\
\hline & & & & & & & & \\
\hline
\end{tabular}

Q8. Think about your eating habits over the last MONTH. About how often did you eat or drink each of the following foods? Remember breakfast, lunch, dinner, snacks, and eating out. Circle one answer in each line.

\begin{tabular}{|l|c|c|c|c|c|c|c|c|}
\hline \multicolumn{1}{|c|}{ TYPE OF FOOD } & Never & $\begin{array}{c}\text { Less } \\
\text { than } \\
\text { once } \\
\text { per } \\
\text { month }\end{array}$ & $\begin{array}{c}1-2 \\
\text { times } \\
\text { per } \\
\text { week }\end{array}$ & $\begin{array}{c}3-4 \\
\text { times } \\
\text { per } \\
\text { week }\end{array}$ & $\begin{array}{c}5-6 \\
\text { times } \\
\text { per } \\
\text { week }\end{array}$ & $\begin{array}{c}1 \\
\text { time } \\
\text { per } \\
\text { day }\end{array}$ & $\begin{array}{c}2 \\
\text { times } \\
\text { per } \\
\text { day }\end{array}$ & $\begin{array}{c}3 \text { or } \\
\text { more } \\
\text { times } \\
\text { per } \\
\text { day }\end{array}$ \\
\hline Cold cereal & 1 & 2 & 3 & 4 & 5 & 6 & 7 & 8 \\
\hline $\begin{array}{l}\text { Skim milk-on cereal or to } \\
\text { drink }\end{array}$ & 1 & 2 & 3 & 4 & 5 & 6 & 7 & 8 \\
\hline $\begin{array}{l}\text { Eggs, fried or scrambled in } \\
\text { margarine, butter, or oil }\end{array}$ & 1 & 2 & 3 & 4 & 5 & 6 & 7 & 8 \\
\hline $\begin{array}{l}\text { Sausage or bacon, regular fat } \\
\text { Margarine or butter on bread, } \\
\text { rolls, pancakes }\end{array}$ & 1 & 2 & 3 & 4 & 5 & 6 & 7 & 8 \\
\hline $\begin{array}{l}\text { Orange juice or grapefruit } \\
\text { juice }\end{array}$ & 1 & 2 & 3 & 4 & 5 & 6 & 7 & 8 \\
\hline
\end{tabular}




\begin{tabular}{|l|c|c|c|c|c|c|c|c|}
\hline Fruit (not juice) & 1 & 2 & 3 & 4 & 5 & 6 & 7 & 8 \\
\hline $\begin{array}{l}\text { Beef or pork hot dogs, } \\
\text { regular fat }\end{array}$ & 1 & 2 & 3 & 4 & 5 & 6 & 7 & 8 \\
\hline $\begin{array}{l}\text { Cheese or cheese spread, } \\
\text { regular fat }\end{array}$ & 1 & 2 & 3 & 4 & 5 & 6 & 7 & 8 \\
\hline $\begin{array}{l}\text { French fries, home fries, or } \\
\text { hash brown potatoes }\end{array}$ & 1 & 2 & 3 & 4 & 5 & 6 & 7 & 8 \\
\hline $\begin{array}{l}\text { Margarine or butter on } \\
\text { vegetables, including } \\
\text { potatoes }\end{array}$ & 1 & 2 & 3 & 4 & 5 & 6 & 7 & 8 \\
\hline $\begin{array}{l}\text { Mayonnaise, regular fat } \\
\text { Salad dressing, regular fat }\end{array}$ & 1 & 2 & 3 & 4 & 5 & 6 & 7 & 8 \\
\hline Rice & 1 & 2 & 3 & 4 & 5 & 6 & 7 & 8 \\
\hline $\begin{array}{l}\text { Margarine, butter, oil on rice } \\
\text { or pasta }\end{array}$ & 1 & 2 & 3 & 4 & 5 & 6 & 7 & 8 \\
\hline
\end{tabular}

Q9. Over the last month, when you prepared foods with margarine or ate margarine, how often did you use reduced-fat margarine?

Did not use Almost About $1 / 4$ of

About $1 / 2 \quad$ About $3 / 4 \quad$ Almostall

Margarine never the time of the time of the time or always
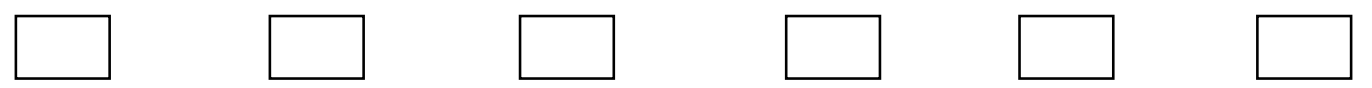

Q10. Overall, when you think about the foods you ate over the last month, would you say your diet was high, medium, or low in fat?

HIGH

MEDIUM

LOW
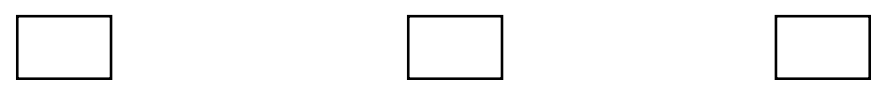


\section{Section 4-Confidence}

We would like to know how confident you are in doing certain activities.

For each of the following questions, please CIRCLE the number that corresponds to your confidence that you can do these tasks regularly.

Q1. How sure are you that you can follow your diet when you have to prepare or share food with other people who do not have diabetes?

$\begin{array}{llllll}\text { I know } & 1 & 2 & 3 & 4 & 5\end{array}$
I cannot

Q2. How sure do you feel that you can choose the appropriate foods to eat when you are hungry (for example, snacks?)

$\begin{array}{llllll}\text { I know } & 1 & 2 & 3 & 4 & 5\end{array}$ I know I can

I cannot

Q3. How sure are you that you can stick to your healthful eating plan when you feel depressed, bored, or tense?

\begin{tabular}{lllllll} 
I know & 1 & 2 & 3 & 4 & 5 & I know I can \\
\hline
\end{tabular}

I cannot

Q4. How sure are you that you can eat smaller portions at dinner?

$\begin{array}{llllll}\text { I know } & 1 & 2 & 3 & 4 & 5\end{array}$ I know I can

I cannot

Q5. How sure are you that you can add less fat than the recipe calls for?

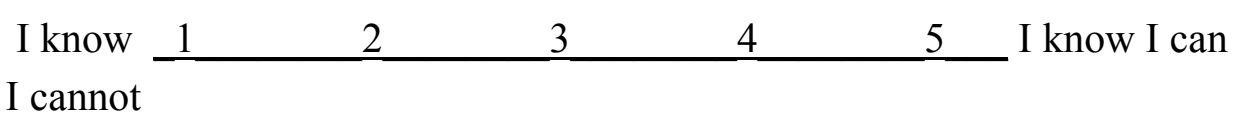


Q11. In the past 7 days, on how many occasions did you eat breakfast, lunch, and dinner?

(Circle one answer on each meal time.)

\begin{tabular}{|c|c|c|c|c|c|c|c|c|}
\hline $\begin{array}{c}\text { Meal } \\
\text { Time }\end{array}$ & Never & & & & & & Daily \\
\hline Breakfast & 0 & 1 & 2 & 3 & 4 & 5 & 6 & 7 \\
\hline Lunch & 0 & 1 & 2 & 3 & 4 & 5 & 6 & 7 \\
\hline Dinner & 0 & 1 & 2 & 3 & 4 & 5 & 6 & 7 \\
\hline
\end{tabular}

Q12. In the past 7 days, how many days did you use the Idaho Plate Method when preparing breakfast, lunch, and dinner? (Circle one answer on each meal line.)

\begin{tabular}{|c|c|c|c|c|c|c|c|c|}
\hline $\begin{array}{c}\text { Meal } \\
\text { Time }\end{array}$ & Never & & & & & & Daily \\
\hline Breakfast & 0 & 1 & 2 & 3 & 4 & 5 & 6 & 7 \\
\hline Lunch & 0 & 1 & 2 & 3 & 4 & 5 & 6 & 7 \\
\hline Dinner & 0 & 1 & 2 & 3 & 4 & 5 & 6 & 7 \\
\hline
\end{tabular}


Appendix R

IPM Lesson Plans

Retrieved from http://www.platemethod.com/downloads.html

\section{The 5 minute Meal Plan}

The Idaho Plate Method has an easy way to help busy healthcare professionals start their patients on a Diabetes or Weight Loss Meal Plan.

Diets are too hard. Everyone has tried them and often failed. Give your patients a Meal Plan they can be Successful with!! At meal time everyone uses a Plate, a Bowl, and a Cup.

1) When patients say they can not diet. Say... Can you divide your plate in $1 / 2$, can you divide it into $1 / 4$ ths. Everyone says Yes

2) Show them the Idaho Plate Method Placemat, or Guide

3) Simply show them that on the top half of the Lunch and Dinner Plate you put your Veggies. $\quad$ Not corn, peas, potatoes, or winter squash.

4) See the section labeled Meat/Protein. They can use any type of meat, but remind them to keep their meats on this part of the plate. Yes, this can decrease fat intake \& cholesterol levels. SIMPLE (The RD can address low fat Meat choices later)

5) Look at the section Breads/ Starches/Grains. These foods just need to stay on this section of the plate. A small bowl can sit here to hold soups, and Cereals.

Now you see the corn, peas, potatoes, \& winter squash belong here. 
6) See the milk group. Encourage them to use a small coffee cup for milk.

The pictures show them the food they can have and how much they can use.

7) See the small dish to hold fruits. A serving size is a small piece of fruit. Yes a small Banana. (For Melons and Berries encourage the small bowl- the RD can review this later)

8) For Breakfast- just skip the Vegetables

9) For men draw a circle by the Breakfast meal and one by the Lunch and Dinner meal and write

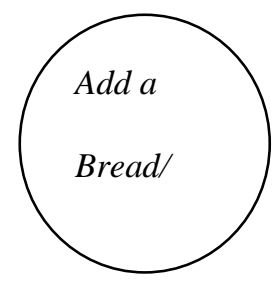
Add a Bread/Starch/or Grain inside it.

They need more calories (The RD can fine tune The meal plan later, and review portion sizes)

10) For snacks women can move their fruit serving to between meals, or add another. Men can have an extra fruit or move their fruit serving to between meals

In 5 minutes you have outlined a Healthy Meal Plan. The simple Visual teaching method is easy for patients to follow: elderly, low literacy, overwhelmed clients, and Non Compliant ones. You have set up Basic Carbohydrate counting, and spaced carbohydrates during the day. Once eating is consistent you can adjust medications. When they go home with an Idaho Plate Method Placemat, and guide they continue to see and be reminded of their meal plan. 
Retrieved from http://www.platemethod.com/downloads.html

Instructions for the Educator Starter Kit

THE PLACEMENT- washable deco foam

Let's look at the Placemat. It shows an easy to follow visual approach to a meal plan. The meals are set up to have approximately $\mathbf{4 5}$ grams of carbohydrate at each meal. Looking at side 1- Breakfast: you see a serving of Milk, Fruit, Bread/Starch/Grain, and Meat. If your client needs an extra serving of bread at a meal, simply draw a circle under the fruit serving and write "add Bread." This shows they will be adding extra Bread serving at this meal. You can write on the Placemat with a dry erase marker when working with clients to develop their meal plan. Then simply wipe clean. Alcohol pads can be used if a dry erase build up occurs. When sending a Placemat home with the client you can use the permanent marker included in the package. You can also use the permanent marker to write extra instructions on the Placemat.

On side 2 - Lunch and Dinner. You see a serving of Milk, Fruit, Bread/Starch/Grain, and Meat. Again you can adjust the meal plan to meet your client's individual needs with the included markers. Some educators write "small dessert" over the fruit serving to show clients how to include desserts. Some educators may mark off the Milk serving at various meals, if the clients will not accept milk products. Some educators prefer to write "can trade for Fruit or Bread" under the word Milk. This shows clients they need the milk group but acknowledges that they may not be able to accept it 3 times a day, and shows them other options. Some educators cross off the Meat group at breakfast, to meet client's preferences.

To individualize a meal plan many educators ask clients for a 1-3 day food history and simply design the meal plan on what the client has been doing. This makes the meal plan more appealing to the client. It still allows the educator the chance to alter the plan to make it more balanced. By showing the similarities to the client's regular meal plan, even while making adjustments, most clients feel more accepting.

Encourage clients to use the Placemats at mealtime. Use either at the table, T.V. tray, or where ever they eat most of their meals. By having the meal plan in front of them it is a gentle reminder for them. Compliance follows. 


\section{PAPER PLACEMAT}

This has the same set up as the Lunch and Dinner side of the deco foam washable plastic placemat. It can be used at lunches, or when addressing large groups, or as a great handout for National Nutrition Month, and other community events. It also works well as a "budget" handout. It can be individualized for clients. Note: clients do not value our drawings so this can be used to save time, money, and increase client compliance.

\section{THE GUIDE}

The Guide has many uses. Many educators use it as the first meal plan in hospitals. Clients overwhelmed by a diagnosis of diabetes find this visual simple to use meal plan something they can follow. On later follow ups the educator can continue to use the plate method while fine tuning portion control and explaining how to include low fat food choices. It has the basics of carbohydrate counting which educators can continue to reinforce. The guide is very helpful for low literacy clients. It is also used for clients who have tried other diets and need something easy to follow.

First, let's look at the side Plate Method for Meal planning. On this side it shows a picture of the plate and how the food is placed on it. Many educators write the clients favorite foods in the various sections of the plate. This way when they go home they know where these foods should be on the plate. Educators also use this as a teaching tool by letting clients write down favorite foods in the section they think they should go and reviewing and correcting it with the clients.

The guide also has helpful information on treating low blood sugars, and blood sugar goals on the handout.

Side 2 has Plate Method Menu Ideas. It shows how to trade similar carbohydrate containing foods. The Idaho Plate method shows a simple approach to Carbohydrate counting. This side also mentions tips for better diabetes control, which educators can review and reinforce in follow up sessions if time allows. 
Side 2 is also excellent in showing clients how to set up meals using the plate method. It shows pictures of a variety of favorite foods. Clients see how they can use the plate and Placemat. Educators use the guide for clients with diabetes, weight control and general nutrition. When using the guide for weight loss and general nutrition educators just cross off or tell clients to ignore the diabetes information. It is still very helpful because it shows the menu ideas. By seeing pictures of meals clients quickly know how to use the plate method, and it is used as a reminder when they get home. With the simple format and pictures they can see what you talked about and they do better!

*The Spanish guide is the same as the English guide but it is written in Spanish with English subtitles. It allows educators to have a simple meal plan for Spanish speaking clients, showing favorite ethnic foods. It also has English text so non-Spanish speaking educators can use the guide easily. It allows everyone a choice of using Spanish or English text. Note the plate does have an extra serving of bread/starch because educators felt they needed the extra serving to meet cultural expectations and increase compliance. Also on the beans are shown on the bread/starch section of the plate and the meat section of the plate. Again educators requested it be listed on both sections. If you are working with stricter carbohydrate counting simply cross off the dish of beans on the meat section of the plate.

How to leaflet/booklet for weight loss \& general Nutrition

This is an easy to follow handout for clients explaining how to use the Idaho plate method placemat, and guide. Educators can use the handout as a take home to remind clients of the information they reviewed. Some educators use the handouts for instruction. While teaching the class the students follow along in the handouts.

How to leaflet/booklet for Diabetes.

This is a simple to use handout for clients with diabetes. It explains how to use the Idaho plate method placemat and guide. Educators can use it as a take home reminder for clients. It is also used in classes. Clients follow along in the handout as the instructor reviews the information. It has extra diabetes care information which clients find helpful. 
Appendix S

\section{Program Evaluation Form}

\section{Education Program Evaluation}

Please circle one number for each item below to indicate how satisfied you were with:

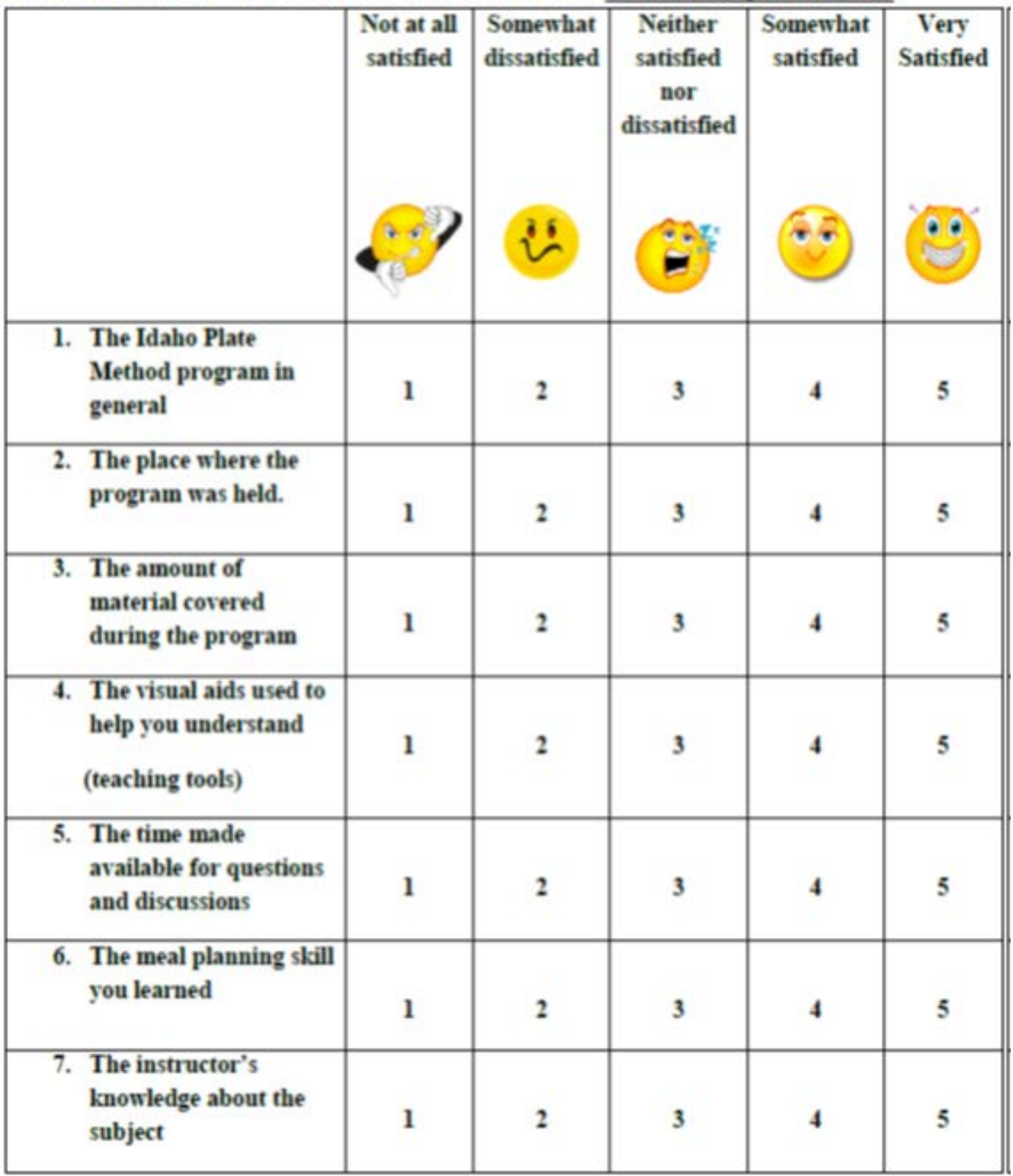




\begin{tabular}{|l|l|l|l|l|l|}
\hline $\begin{array}{l}\text { 8. The helpfulness of the } \\
\text { instructor and others } \\
\text { to ensure your } \\
\text { understanding }\end{array}$ & 1 & 2 & 3 & 4 & 5 \\
\hline $\begin{array}{l}\text { 9. The helpfulness of the } \\
\text { clinic staff during the } \\
\text { program }\end{array}$ & 1 & 2 & 3 & 4 & 5 \\
\hline
\end{tabular}

How likely are you to participate in other self-management programs offered at Robert C. Byrd Clinic?

$$
\text { Unlikely } \begin{array}{llllll}
1 & 2 & 3 & 4 & 5 & \text { Very Likely }
\end{array}
$$

Do you have any other comments about the program or your experience? If so, we would like to know what are we doing right, or how can we improve? Please write your comments below.

PLEASE RETURN TO THE INSTRUCTOR WHEN FINISHED

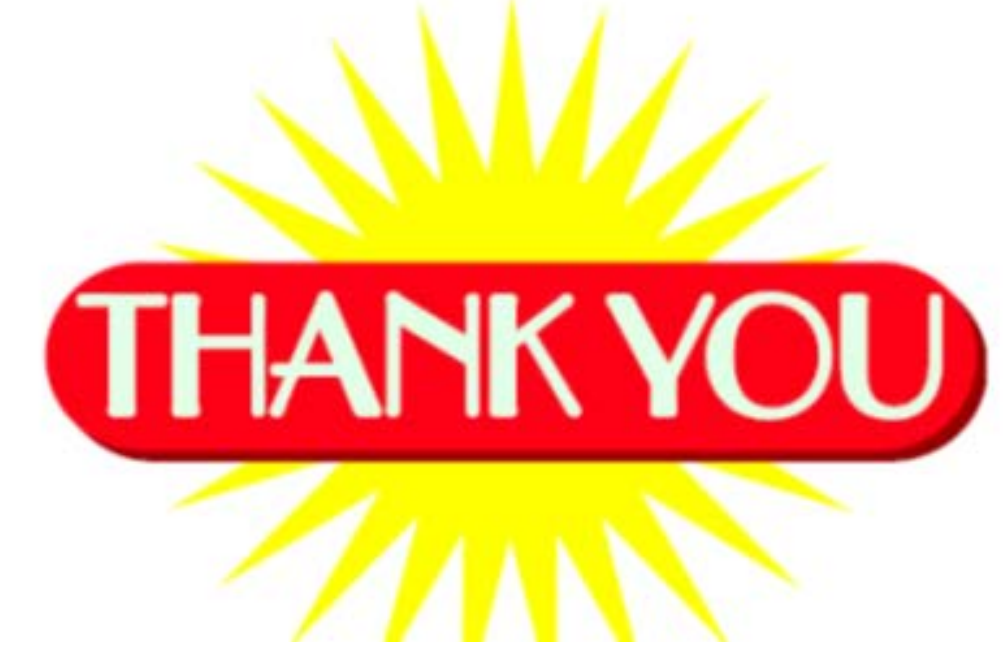




\section{Appendix T}

\section{3-Month Mid-Point Telephone Script}

An Evaluation of the Idaho Plate Method for Diabetic Education for Adults with Limited Health Literacy

\section{Three Month Mid-Point Telephone Contact Script}

Date:

Participant ID Number:

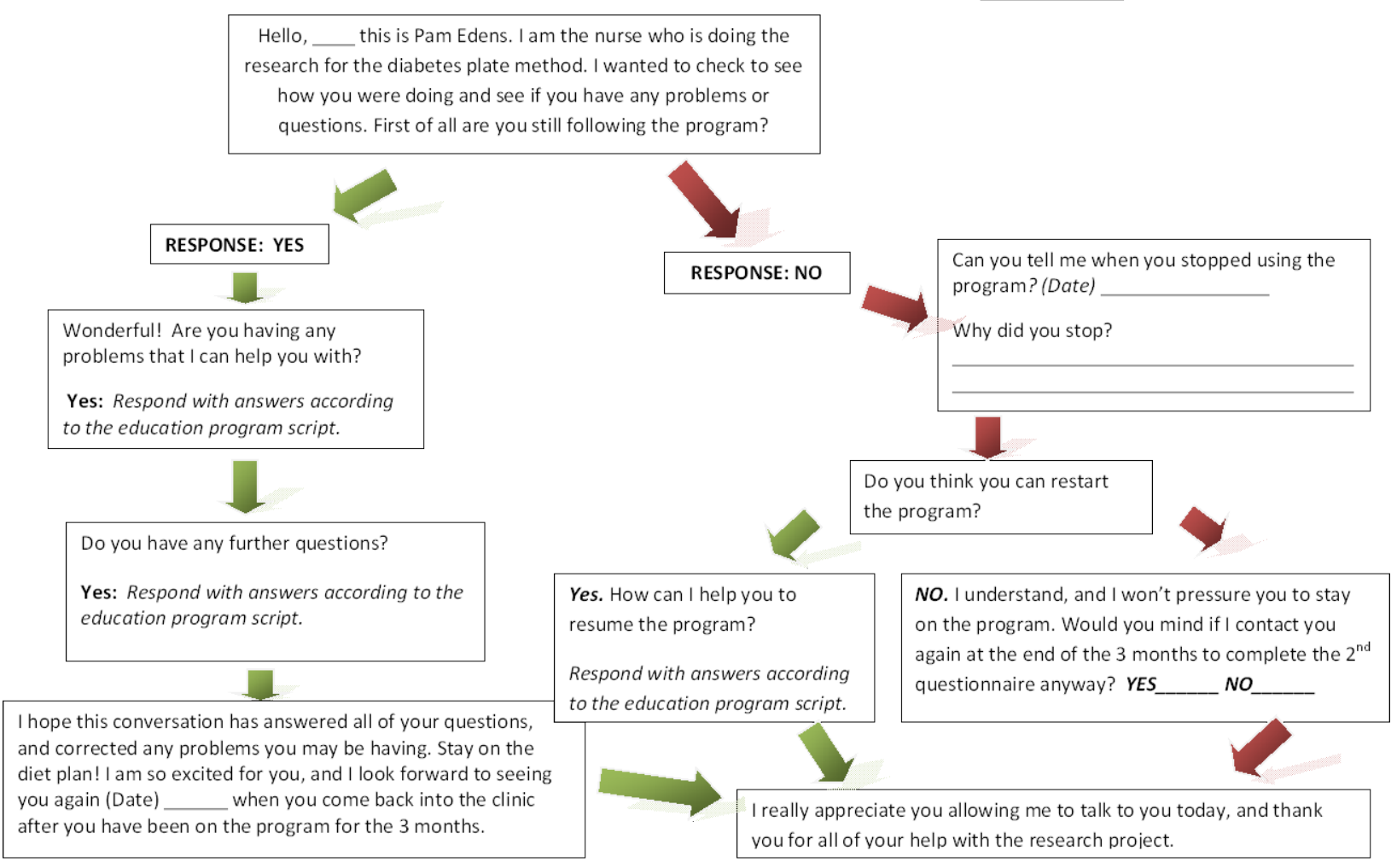




\section{Appendix U}

\section{3-Month Follow-up Telephone Script}

An Evaluation of the Idaho Plate Method for Diabetic Education for Adults with Limited Health Literacy

Three Month End-Point Telephone Contact Script

Date:

Participant ID Number:

Hello,

this is Pam Edens. I am the nurse who is doing the research study with the diabetes plate method. I wanted to remind you that the 3 months is coming to an end on: (Date) . When would be a convenient time for you to come back to the clinic to complete the $2^{\text {nd }}$ questionnaire to complete the research study? (Date) (Time) OK, great! I have your appointment with me on (Date) (Time) . I look forward to seeing you then.

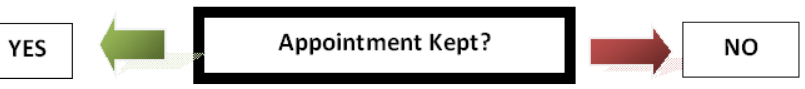

Do you have any questions about the study? couldn't keep your appointment with me at Robert C. Byrd Clinic to complete the $2^{\text {nd }}$ questionnaire portion of the Idaho Plate Method research study. I hope you and your family are well.

NO. Ok. I understand. Your information is very important to me. I would like to call you later if I can. Can you give me a day and time when I can call you so we can complete the $2^{\text {nd }}$ questionnaire?

Yes: (Date) (Time)

No-Thank you for your help with my research study.

Allow time for participant to respond.

Do you have time now to complete the questionnaire over the telephone? It should take about 15 minutes. 
Appendix V

\section{Provider Notification Letter}

, 2012

To:

Robert C. Byrd Clinic

400 N. Jefferson St.

Lewisburg, WV 24901

From: Pamela L Edens, MSN, APRN, FNP-BC

Doctorate of Nursing Practice Student

West Virginia University, School of Nursing

RE:

This letter is to inform you that your patient has agreed to participate in a research study for adult patients with type 2 diabetes at Robert C. Byrd Clinic. Glycemic control will be used as one of the evaluation markers. Therefore, could you please order an HbA1c after:

2012 ?

Thank you,

Pamela L. Edens 